
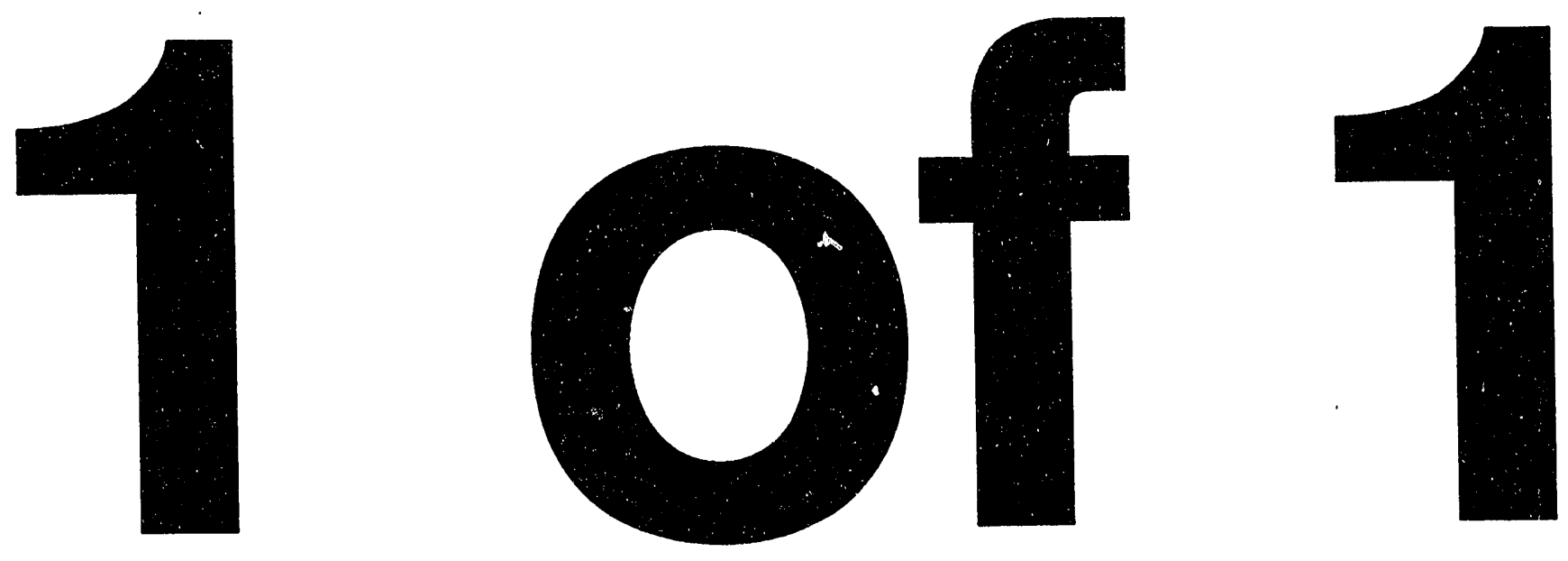


\section{CHEMICAL CONSTITUENTS IN WATER FROM WELLS IN THE VICINITY OF THE NAVAL REACTORS FACILITY, IDAHO NATIONAL ENGINEERING LABORATORY, IDAHO, 1990-91}

By Roy C. Bartholomay, LeRoy L. Knobel, and Betty J. Tucker

\section{U.S. GEOLOGICAL SURVEY}

\section{Open-File Report 93-34}

\section{Prepared in cooperation with the U.S. DEPARTMENT OF ENERGY DISCLAIMER}

This report was prepared as an account of work sponsored by an agency of the United States Government. Neither the United States Government nor any agency thereof, nor any of their employees, makes any warranty, express or implied, or assumes any legal liability or responsibility for the accuracy, completeness, or usefulness of any information, apparatus, product, or process disclosed, or represents that its use would not infringe privately c,wned rights. Reference herein to any specific commercial product, process, or service by trade name, trademark, manufacturer, or otherwise does not necessarily constitute or imply its endorsement, recommendation, or favoring by the United States Government or any agency thereof. The views and opinions of authors expressed herein do not necessarily state or reflect those of the United States Government or any agency thereof.

Idaho Falls, Idaho

January 1993

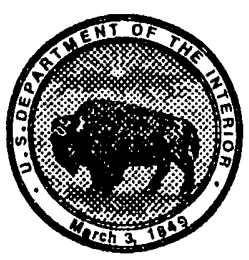




\section{U.S. DEPARTMENT OF THE INTERIOR \\ MANUEL LUJAN, JR., Secretary}

\section{U.S. GEOLOGICAL SURVEY}

Dallas L. Peck, Director

For additional information write to:

Project Chief

U.S. Geological Survey

INEL, MS 4148

P.O. Box 2230

Idaho Falls, ID 83403
Copies of this report can be purchased from:

U.S. Geological Survey

Books and Open-File Reports Section

Box 25425, Mail Stop 517

Federal Center

Denver, CO 80225-0425 


\section{CONTENTS}

Page

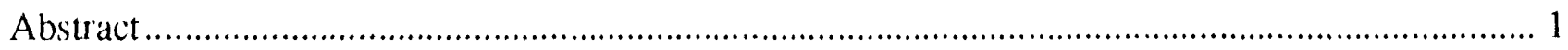

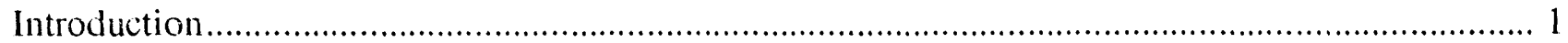

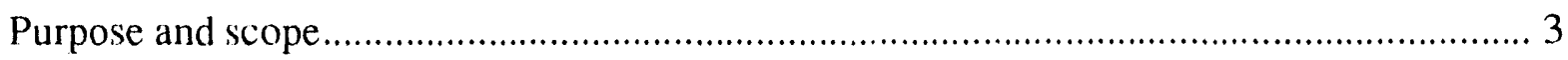

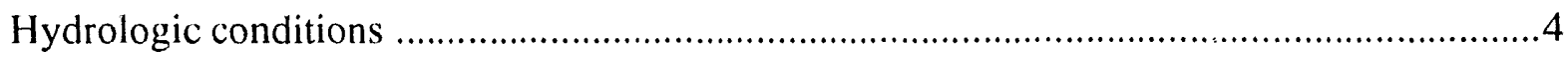

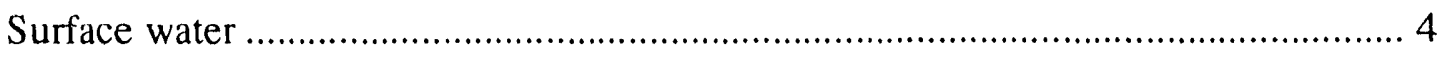

Ground water ............................................................................................. 4

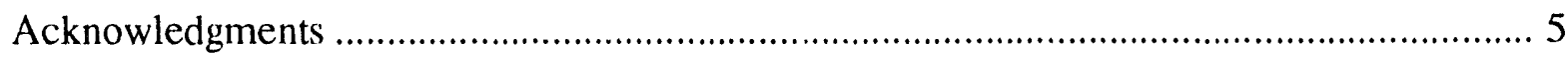

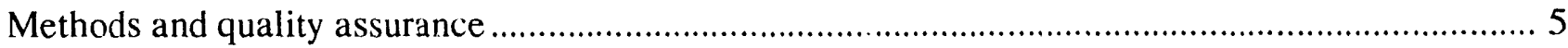

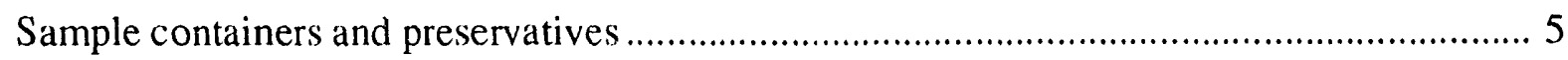

Well locations and sample collection .................................................................... 5

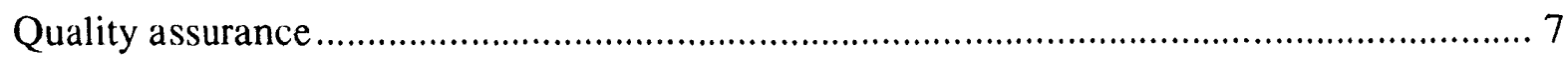

Guidelines for interpreting results of radiochemical analyses......................................... 7

Calculation of estimated experimental standard errors............................................... 8

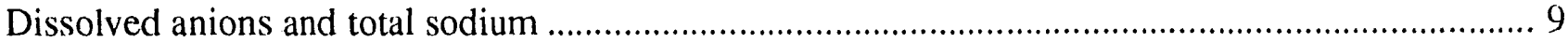

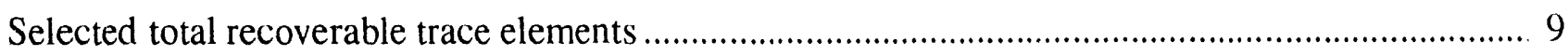

Nutrients, organic carbon, phenols, and turbidity ............................................................. 11

Extractable acid and base/neutral organic compounds ......................................................... 12

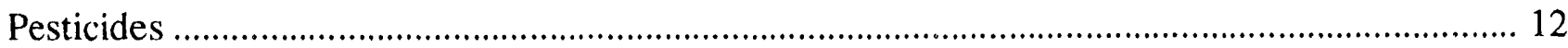

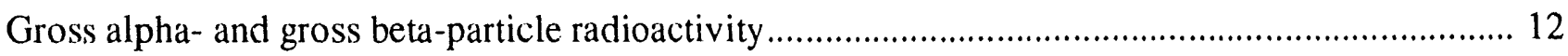

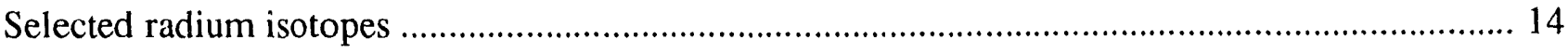

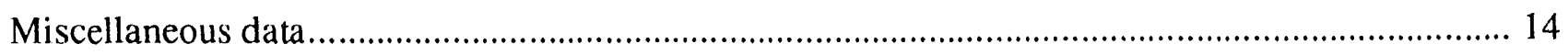

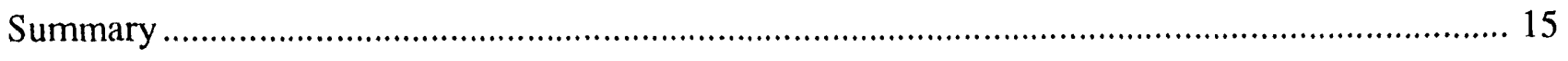

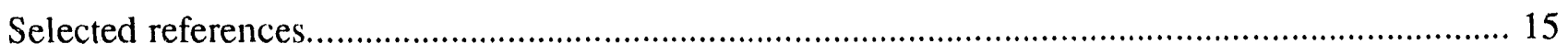

\section{ILLUSTRATIONS}

Figures 1-2. Maps showing:

1. Location of the Idaho National Engineering Laboratory, Naval Reactors

Facility, and other selected facilities. 
2. Location of wells, Naval Reactors Facility and vicinity, Idaho National

Engineering Laboratory

\section{TABLES}

Table 1. Containers and preservatives used for water samples, Naval Reactors Facility and vicinity 18

2. Results of field measurements for $\mathrm{pH}$, specific conductance, and temperature of water, Naval Reactors Facility and vicinity

3. Concentrations of dissolved anions and total sodium in water, Naval Reactors

Facility and vicinity 23

4. Statistical parameters for dissolved anions and total sodium, by well 26

5. Concentrations of selected total recoverable trace elements in water, Naval Reactors Facility and vicinity

6. Statistical parameters for selected total recoverable trace elements, by well

7. Concentrations of selected dissolved trace elements in water from Water

Supply INEL-1, in the vicinity of the Naval Reactors Facility

8. Concentrations of dissolved nutrients in water, Naval Reactors Facility and vicinity 38

9. Concentrations of total organic carbon and total phenols in water, and turbidity, Naval Reactors Facility and vicinity

10. Statistical parameters for dissolved nutrients, total organic carbon, total phenols, and turbidity, by well

11. Extractable acid and base/neutral organic compounds for which water samples were analyzed.

12. Concentrations of selected extractable acid and base/neutral organic compounds in water, Naval Reactors Facility and vicinity 48

13. Pesticides for which water samples were analyzed 51

14. Concentrations of gross alpha-particle radioactivity in water, Naval Reactors Facility and vicinity. 52 
15. Statistical paraneters for gross alpha-particle radioactivity expressed as uranium and thorium-23(), by well

16. Concentrations of gross beta-particle radioactivity in water, Naval Reactors

Facility and vicinity

17. Statistical parameters for gross beta-particle radioactivity expressed as strontium-90 in equilibrium with yttrium-9() and as cesium-137, by well

18. Concentrations of radium-226 and radium-228 in water, Naval Reactors Facility and vicinity

19. Statistical parameters for radium-226 and radium-228, by well

20. Purgeable organic compounds for which water samples were analyzed

21. Concentrations of selected total recoverable trace elements in water from the Central Facilities Area water supply and the Naval Reactors Facility water supply....... 70

\section{CONVERSION FACTORS, VERTICAL DATUM, AND ABBREVIATED WATER-QUALITY UNITS}

Multiply

acre-foot (acre-ft)

foot $(\mathrm{ft})$

foot per mile $(\mathrm{ft} / \mathrm{mi})$

inch (in.)

mile (mi)

picocurie per liter $(\mathrm{pCi} / \mathrm{L})$

square mile $\left(\mathrm{mi}^{2}\right)$
By

0.3048

0.1646

25.4

0.037

2.59()
To Obtain

cubic meter

meter

meter per kilometer

millimeter

kilometer

becquerel per liter

square kilometer

For temperature, degrees Celsius $\left({ }^{\circ} \mathrm{C}\right)$ may be converted to degrees Fahrenheit $\left({ }^{\circ} \mathrm{F}\right)$ by using the equation: ${ }^{\circ} \mathrm{F}=(1.8)\left({ }^{\circ} \mathrm{C}\right)+32$.

Sea level: In this report, "sea level" refers to the National Geodetic Vertical Datum of 1929--a geodetic datum derived from a general adjustment of the first-order level nets of the United States and Canada, formerly called Sea Level Datum of 1929.

Abbreviated water-quality units used in report: $\mathrm{mg} / \mathrm{L}$ (milligram per liter); $\mu \mathrm{g} / \mathrm{L}$ (microgram per liter); and $\mu \mathrm{S} / \mathrm{cm}$ (microsiemens per centimeter at 25 degrees Celsius). 


\title{
CHEMICAL CONSTITUENTS IN WATER FROM WELLS IN THE VICINITY OF THE NAVAL REACTORS FACILITY, IDAHO NATIONAL ENGINEERING LABORATORY, IDAHO, 1990-91
}

\author{
By \\ Roy C. Bartholomay, LeRoy L. Knobel, and Betty J. Tucker
}

\begin{abstract}
The U.S. Geological Survey, in response to a request from the U.S. Department of Energy's Pittsburgh Naval Reactors Office, Idaho Branch Office, sampled 12 wells as part of a long-term project to monitor water quality of the Snake River Plain aquifer in the vicinity of the Naval Reactors Facility, Idaho National Engineering Laboratory, Idaho. Water samples were analyzed for manmade contaminants and naturally occurring constituents. Sixty samples were collected from eight groundwater monitoring wells and four production wells. Ten quality-assurance samples also were collected and analyzed.

Most of the samples contained concentrations of total sodium and dissolved anions that exceeded reporting levels. The predominant category of nitrogen-bearing compounds was nitrite plus nitrate as nitrogen. Concentrations of total organic carbon ranged from less than 0.1 to 2.2 milligrams per liter. Total phenols in 52 of 69 samples ranged from 1 to 8 micrograms per liter. Extractable acid and base/ neutral organic compounds were detected in water from 16 of 69 samples.

Concentrations of dissolved gross alpha- and gross beta-particle radioactivity in all samples exceeded the reporting level. Radium-226 concentrations were greater than the reporting level in 63 of 68 samples.

\section{INTRODUCTION}

The Idaho National Engineering Laboratory (INEL), encompassing about $890 \mathrm{mi}^{2}$ of the eastern Snake River Plain in southeastern Idaho (fig. 1), is operated by the U.S. Department of Energy. INEL facilities are used in the development of peacetime atomic-energy applications, nuclear safety research, defense programs, and advanced energy concepts. Liquid radionuclide and chemical wastes generated at these facilities have been discharged to onsite infiltration ponds and disposal wells since 1952. Liquid-waste disposal has resulted in detectable concentrations of several chemical constituents in water from the Snake River Plain aquifer underlying the INEL (Orr and Cecil, 1991, p. 2).
\end{abstract}




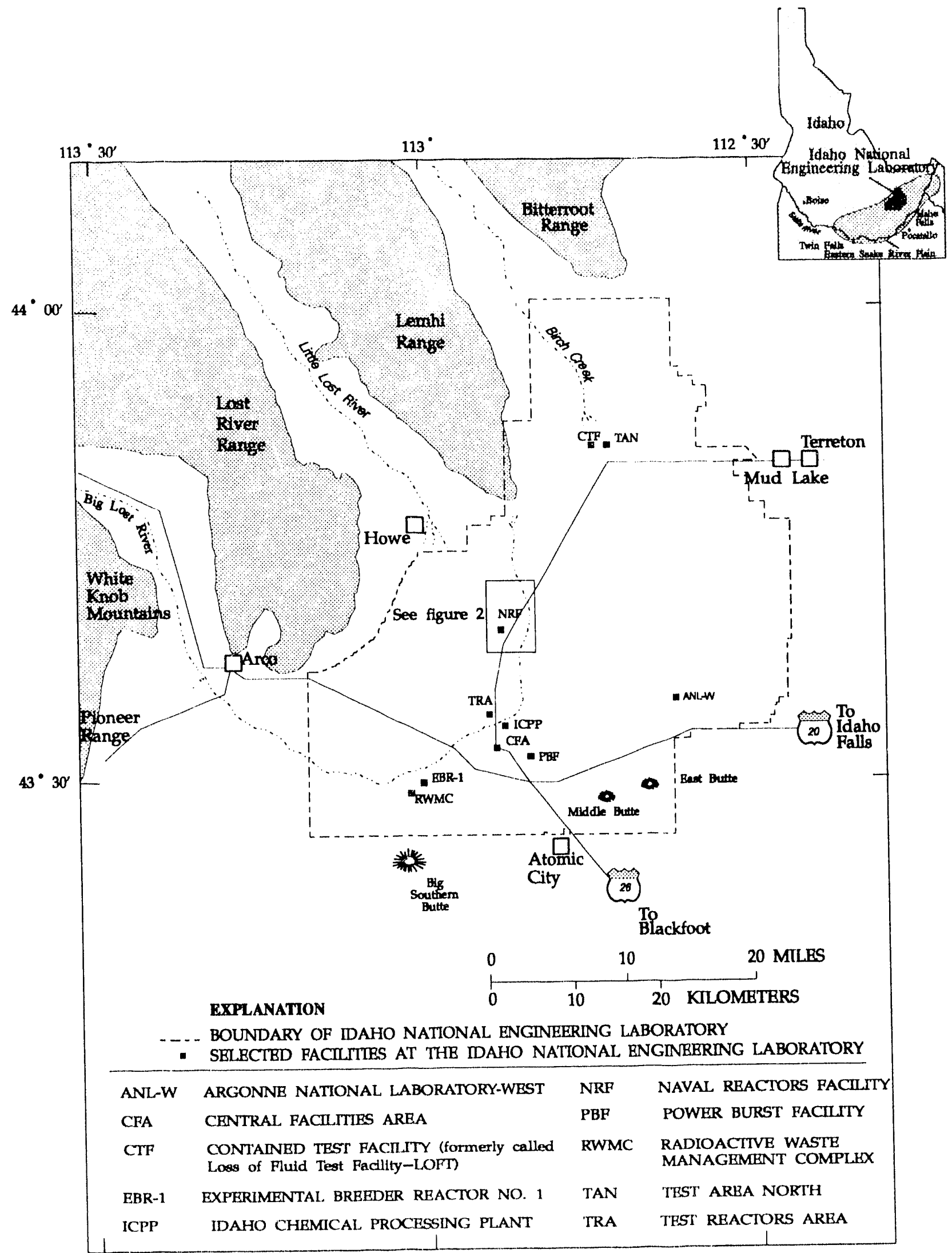

Figure 1.- Location of the Idaho National Engineering Laboratory, Naval Reactors Facility, and other selected facilities. 
The U.S. Department of Energy requires information about the mobility of liquid radionuclideand chemical-waste constituents in the Snake River Plain aquifer. Waste-constituent mobility is, in part, determined by (1) the rate and direction of ground-water flow; (2) the locations, quantities, and methods of waste disposal; (3) waste-constituent chemistry; and (4) the geochemical processes taking place in the aquifer (Orr and Cecil, 1991, p. 2). This study was conducted by the U.S. Geological Survey (USGS) in cooperation with the U.S. Department of Energy's Pittsburgh Naval Reactors Office, Idaho Branch Office.

\section{Purpose and Scope}

In 1989, the Idaho Branch Office of the Pittsburgh Naval Reactors Office, U.S. Department of Energy, requested that the USGS initiate a water-quality data-collection program in the vicinity of the Naval Reactors Facility (NRF) at the INEL (fig. 1). The purpose of the data-collection program is to provide the Idaho Branch Office with water-chemistry data to evaluate the impact of NRF activities on the water quality of the Snake River Plain aquifer.

The data-collection program consists of three rounds of sample collection and chemical analyses. Round one was a one-time sampling of each well and an analysis for a comprehensive suite of chemical constituents (Knobel and others, 1992) that approximates those contained in the U.S. Environmental Protection Agency's Ground-Water Monitoring List-Appendix IX (U.S. Environmental Protection Agency, 1989, p. 636-642). Round two consisted of collection of 60) samples and analyses for chemical constituents listed in Appendix III-EPA Interim Primary Drinking Water Standards, the constituents listed as parameters for establishing ground-water quality, and selected measurements used as indicators of ground-water contamination (U.S. Environmental Protection Agency, 1989, p. 66()-661, 730). Round-two samples also were analyzed for copper, nickel, zinc, and extractable acid and basc/neutral compounds. Round three is ongoing. Samples are collected quarterly from each well and analyzed for chloride, chromium, iron, lead, mercury, nickel, nitrate as nitrogen, silver, sodium, sulfate, and measurements of gross alpha- and gross betaradioactivity, $\mathrm{pH}$, specific conductance, and total organic carbon. As a result of expanded laboratory procedures, all three rounds of sampling include analyses for constituents in addition to those described above.

The purpose of this report is to present a compilation of round-two water-chemistry data collected during 199()-91. Round-two water-chemistry data from two additional wells will be presented in a subsequent report. 


\section{Hydrologic Conditions}

The Snake River Plain aquifer is one of the most productive aquifers in the United States (USGS, 1985, p. 193). The aquifer consists of a thick sequence of basalts and sedimentary interbeds filling a large, arcuate, structural basin in southeastern Idaho (fig. 1).

Surface Water.-The Big Lost River drains more than $1,4()() \mathrm{mi}^{2}$ of mountainous area that includes parts of the Lost River Range and the Pioneer Range west of the INEL (fig. 1). Flow in the Big Lost River infiltrates to the Snake River Plain aquifer along its channel and at sinks and playas at the river's terminus. Since 1958, excess runoff has been diverted to spreading areas in the southwestern part of the INEL where much of the water rapidly infiltrates to the aquifer. Other surface drainages that provide recharge to the Snake River Plain aquifer at the INEL include Birch Creek and the Little Lost River (fig. 1) (Orr and Cecil, 1991, p. 23).

Ground water.- Recharge to the Snake River Plain aquifer is principally from infiltration of applied irrigation water, infiltration of streamflow, and ground-water inflow from adjoining mountain drainage basins. Some recharge may be from direct infiltration of precipitation, although the small amount of annual precipitation on the plain ( 8 in. at the INEL), evapotranspiration, and the great depth to water (in places exceeding 90() $\mathrm{ft}$ ) probably minimize this source of recharge (Orr and Cecil, 1991 , p. 22-23).

Water in the Snake River Plain aquifer moves principally through fractures and interflow zones in the basalt. A large amount of the ground water in the aquifer moves through the upper 80() $\mathrm{ft}$ of saturated rocks (Mann, 1986, p. 21). Hydraulic conductivity of basalt in the upper 8()() $\mathrm{ft}$ of the aquifer generally is 1 to 10() $\mathrm{ft} /$ day. Hydraulic conductivity of underlying rocks is several orders of magnitude smaller. The base of the Snake River Plain aquifer at the INEL probably ranges from about 850 to $1,220 \mathrm{ft}$ below land surface (Orr and Cecii, 1991, p. 25).

Depth to water in wells completed in the Snake River Plain aquifer ranges from about $200 \mathrm{ft}$ in the northern part of the INEL to more than 9()() $\mathrm{ft}$ in the southeastern part; in the vicinity of the NRF, depth to water is about $375 \mathrm{ft}$. In July 1988 , the altitude of the water table was about 4,590 $\mathrm{ft}$ above sea level near the TAN (Test Area North), about 4,420 ft above sea level near the RWMC (Radioactive Waste Management Complex), and about 4,5()() ft above sea level near the NRF. Water moved southward and southwestward beneath the INEL at an average hydraulic gradient of about $4 \mathrm{ft} / \mathrm{mi}$. Water generally moved southward beneath the $1 \mathrm{NEL}$ at a hydraulic gradient that ranged from about 1 to $15 \mathrm{ft} / \mathrm{mi}$. From July 1985 to July 1988, water-level changes in INEL wells ranged from a 26.8-ft decline near the RWMC to a 4.3-ft rise north of the TAN; the water-level decline was about 1 to $3 \mathrm{ft}$ near the NRF. Water levels generally declined in the southern two-thirds of the INEL during that time and rose in the northern one-third (Orr and Cecil, 1991, p. 25-27). 
Ground water moves suuthwestward from the INEL and eventually discharges from springs along the Snake River downstream from Twin Falls, about 10() mi southwest of the INEL. Approximately 4.3 million acre-ft of ground water discharged from these springs in 1988 (Mann, 1989, p. 2).

\section{Acknowledgments}

The authors are grateful to Steven J. Price, Kelly D. Willie, and Kent R. Shelley of Westinghouse Electric Corporation for providing logistical support during sample collection and to Michael $\mathrm{v}$. Rupert of the USGS and Kelly D. Willie of Westinghouse Electric Corporation for technically reviewing the manuscript.

\section{METHODS AND QUALITY ASSURANCE}

The methods used for collecting samples for chemical analyses generally followed the guidelines established by the USGS (Goerlitz and Brown, 1972; Stevens and others, 1975; Wood, 1981; Claassen, 1982; W.L. Bradford, USGS, written commun., 1985; Wershaw and others, 1987; Fishman and Friedman, 1989; Hardy and others, 1989). The methods used in the field and the quality assurance practices are described in the following sections.

\section{Sample Containers and Preservatives}

Sample containers and preservatives differed depending on the constituent(s) for which analyses were requested. Samples analyzed by the USGS's National Water Quality Laboratory (NWQL) were placed in containers and preserved in accordance with laboratory requirements specified by Pritt and Jones (1989). Containers and preservatives were supplied by the NWQL and had undergone a rigorous quality-control procedure (Pritt, 1989, p. 75) to eliminate sample contamination. The containers and preservatives used for this study are listed in table 1 (all tables located at the end of this report).

\section{Well Locations and Sample Collection}

Sixty samples were collected from 12 wells (fig. 2): 8 USGS ground-water monitoring wells (12, 15, 17, 97-99, 102, and Water Supply INEL-1); and 4 production wells (NRF-1, -2, -3, and -4). The ground-water monitoring wells were equipped with dedicated submersible pumps. The production wells were equipped with line-shaft turbine pumps. The production wells are located within the NRF boundary; USGS 102 is located west of the boundary (fig. 2); USGS 12, 15, and 17 are upgradient of the facility; and the remaining monitoring wells are located downgradient (Orr and Cecil, 1991, p. 26). 


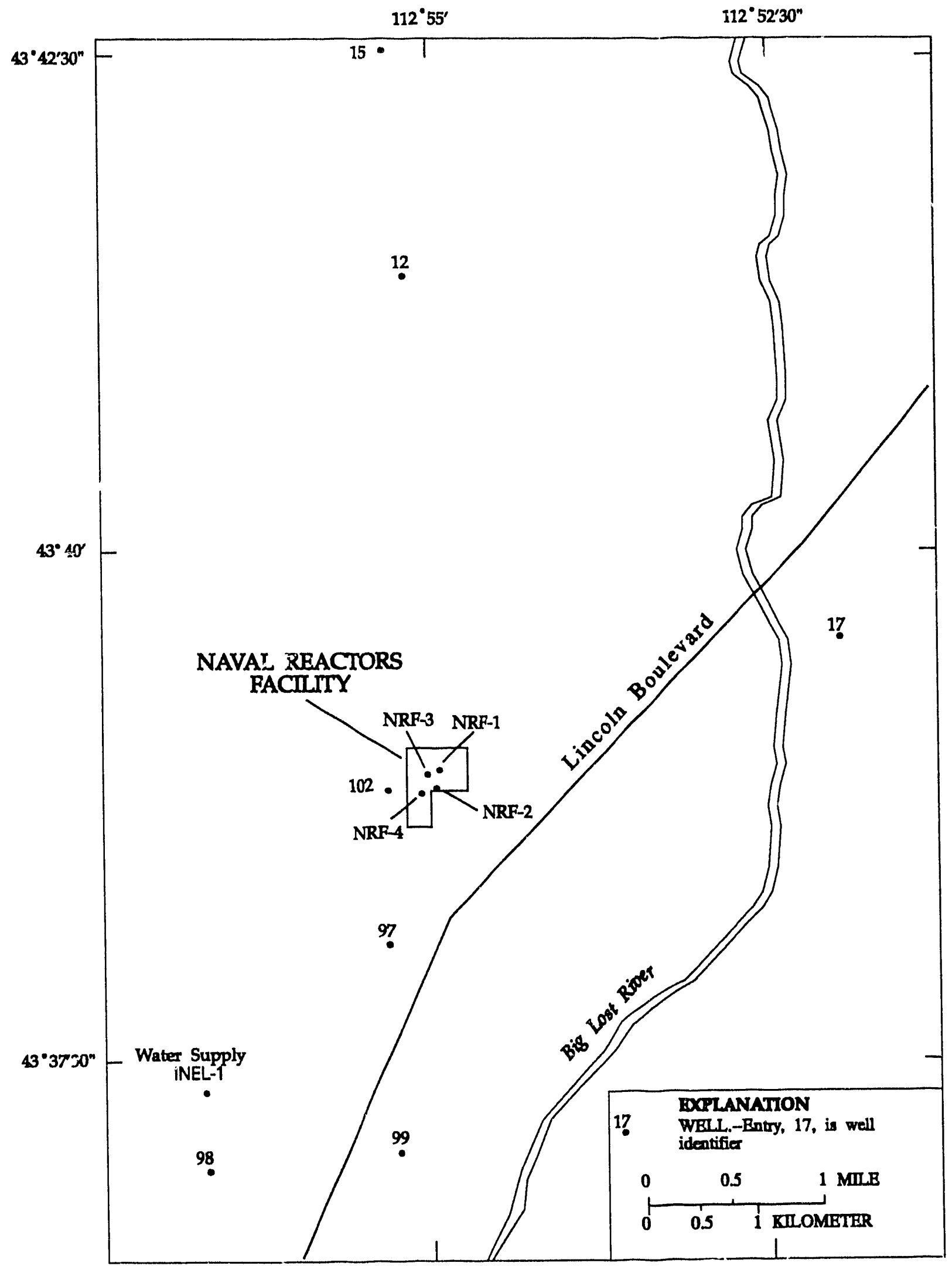

Figure 2. - Location of wells, Naval Reactors Facility and vicinity, Idaho National Engineering Laboratory. 
Samples from wells equipped with dedicated submersible pumps were collected from a portable sampling apparatus; samples from wells equipped with turbine pumps were obtained from a stainlesssteel port on the pump discharge line. All portable equipment was decontaminated after each sample was collected. After collection, sample containers were sealed with laboratory film, labeled, and stored under secured conditions. Sample containers later were placed in ice chests, sealed, and shipped by overnight-delivery mail to the NWQL.

Conditions at the wells during sample collection were recorded in a field logbook and a chain-ofcustody record was used to track samples from the time of collection until delivery to the NWQL. These records are available for inspection at the USGS Project Office at the INEL. The results of field measurements for $\mathrm{pH}$, specific conductance, and water temperature are listed in table 2.

\section{Quality Assurance}

A detailed description of internal quality control and the overall quality-assurance practices used by the NWQL is provided in reports by Friedman and Erdmann (1982) and Jones (1987). The water samples were collected in accordance with a quality-assurance plan for quality-of-water activities conducted by personnel at the INEL Project Office; the plan was finalized in June 1989 and is available for inspection at the USGS's Project Office at the INEL. A comparative study to determine agreement between analytical results for water-sample pairs by laboratories involved in the INEL Project Office's quality-assurance program was summarized by Wegner (1989).

Approximately 10 percent of the water samples collected during round-two sampling were qualityassurance samples. Samples QAS-2, 3, 5, 6, 7, 9, 10, 11, and 12 were replicates of samples from NRF-2, USGS 97, USGS 98, USGS 15, USGS 99, Water Supply INEL-1, USGS 97, USGS 102, and NRF-4, respectively. Sample QAS-8 was a blank of deionized water from the Radiological and Environmental Sciences Laboratory (RESL), and will not be included in the discussion of the various constituents measured.

\section{Guidelines for Interpreting Results of Radiochemical Analyses}

Concentrations of radionuclides are reported with an estimated sample standard deviation, $\mathbf{s}$, that is obtained by propagating sources of analytical uncertainty in measurements. The following guidelines for interpreting analytical results are based on an extension of a method proposed by Currie (1984).

In the analysis for a particular radionuclide, laboratory measurements are made on a target sample and a prepared blank. Instrument signals for the sample anci the blank vary randomly. Therefore, it is essential to distinguish between two key aspects of the problem of detection: (1) the instrument

signal for the sample must be larger than the signal observed for the blank before the decision can be made that the radionuclide was detected; and (2) an estimation must be made of the minimum radionuclide concentration that will yield a sufficiently large observed signal before the correct 
decision can be made for detection or nondetection of the radionuclide. The first aspect of the problem is a qualitative decision based on an observed signal and a definite criterion for detection. The second aspect of the problem is an estimation of the detection capabilities of a given measurement process.

In the laboratory, instrument signals must exceed a critical level before the qualitative decision can be made as to whether the radionuclide was detected. Radionuclide concentrations that equal 1.6s meet this criterion; at $1.6 \mathrm{~s}$, there is a 95-percent probability that the correct conclusion-not detectec - will be made. Given a large number of samples, as many as 5 percent of the samples with measured concentrations larger than or equal to $1.6 \mathrm{~s}$ which were concluded as being detected, might not contain the radionuclide. These measurements are referred to as false positives and are errors of the first kind in hypothesis testing.

Once the critical level of 1.6s has been defined, the ininimum detectable concentration may be determined. Radionuclide concentrations that equal $3 \mathrm{~s}$ represent a measurement at the minimum detectable concentration. For true concentrations of $3 \mathbf{s}$ or larger, there is a 95 -percent or larger probability that the radionuclide was detected in a sample. Given a large number of samples, the conclusion-not detected-will be made in 5 percent of the samples that contain true concentrations at the minimum detectable concentration of $3 \mathrm{~s}$. These measurements are referred to as false negatives and are errors of the second kind in hypothesis testing.

True radionuclide concentrations between 1.6s and $3 \mathrm{~s}$ have larger errors of the second kind. That is, there is a larger-than-5-percent probability of false negative results for samples with true concentrations between $1.6 \mathrm{~s}$ and $3 \mathrm{~s}$. Although the radionuclide might have been detected, such detection may not be considered reliable; at $1.6 \mathrm{~s}$, the probability of a false negative is about 50 percent.

The critical level and minimum detectable concentration are based on counting statistics alone and $\mathrm{d}$ not include systematic or random errors inherent in laboratory procedures. The values 1.6s and $3 \mathrm{~s}$ vary slightly with background or blank counts, with the number of gross counts for individual analyses, and for different radionuclides. In this report, radionuclide concentrations less than $3 \mathbf{s}$ are considered to be below a "reporting level." The critical level, minimum detectable concentration, and reporting level aid the reader in the interpretation of analytical results and do not represent absolute concentrations of radioactivity which may or may not have been detected.

\section{Calculation of Estimated Experimental Standard Errors}

The analytical results for radionucides are presented with calculated analytical uncertainties. There is about a 67 -percent probability that the true radionuclide concentration is in a range of the reported concentration plus or minus the uncertainty. The uncertaintics are expressed as one sample standard deviation. The associated uncertainties presented with mean concentrations are experimental 
standard errors and are an estimate of the uncertainty of the mean concentration. The estimated experimental standard errors (EESE) were calculated with the following equation (Iman and Conover, 1983, p. 158):

$$
\begin{aligned}
\text { EESE } & =\sigma /(n)^{0.5} \\
\text { where } \sigma & =\text { population standard deviation, and } \\
n & =\text { sample size. }
\end{aligned}
$$

The population standard deviation, $\sigma$, is customarily estimated by $\mathbf{s}$ (the sample standard deviation) (Iman and Conover, 1983, p. 106). The sample standard deviation is the square root of the sample variance (Iman and Conover, 1983, p. 100-101).

\section{DISSOLVED ANIONS AND TOTAL SODIUM}

Water samples were analyzed for concentrations of dissolved bromide, chloride, fluoride, ard sulfate, and concentrations of total sodium (table 3). Statistical parameters for the dissolved anions and total sodium by well ar given in table 4 . Concentrations of bromide in 69 samples ranged from less than the reporting level i 0.01 to $0.34 \mathrm{mg} / \mathrm{L}$. The median and mean concentrations of bromide in 67 samples were 0.06 and $0.08 \mathrm{mg} / \mathrm{L}$, respectively (table 4). Concentrations of chloride in 69 samples ranged from 4.8 to $140 \mathrm{mg} / \mathrm{L}$ and were distributed about median and mean concentrations of 32 and $36 \mathrm{mg} / \mathrm{L}$, respectively. Concentrations of fluoride in 69 samples ranged from less than the reporting level of 0.1 to $0.7 \mathrm{mg} / \mathrm{L}$. The median and mean concentrations of fluoride in 55 samples were 0.2 and $0.3 \mathrm{mg} / \mathrm{L}$, respectively. Concentrations of sulfate in 69 samples ranged from 15 to $160 \mathrm{mg} / \mathrm{L}$ and were distributed about median and mean concentrations of 34 and $37 \mathrm{mg} / \mathrm{L}$, respectively. Concentrations of sodium in 68 samples ranged from 5.7 to $20 \mathrm{mg} / \mathrm{L}$ and were distributed about median and mean concentrations of 13 and $13 \mathrm{mg} / \mathrm{L}$, respectively.

\section{SELECTED TOTAL RECOVERABLE TRACE ELEMENTS}

Water samples were analyzed for concentrations of total recoverable arsenic, barium, cadmium, chromium, copper, iron, lead, manganese, mercury, nickel, selenium, silver, and zinc (table 5). Statistical parameters for selected trace elements by well are given in table 6 . An additional water sample was collected from Water Supply INEL-1 (fig. 2) on July 30, 1990), and analyzed for concentrations of selected dissolved trace elements. The results of the analyses are given in table 7 and can be compared to concentrations of total trace elements given in table 5 .

Arsenic.-Concentrations of arsenic in 69 samples ranged from 1 to $12 \mu \mathrm{g} / \mathrm{L}$ and were distributed about median and mean concentrations of 2 and $2 \mu \mathrm{g} / \mathrm{L}$, respectively (table 6 ). 
Barium.-Concentrations of barium in 68 samples ranged from less than the reporting level of 100 to $200 \mu \mathrm{g} / \mathrm{L}$. The median and mean concentrations of 25 samples were 100 and $100 \mu \mathrm{g} / \mathrm{L}$, respectively (table 6).

Cadmium.-Concentrations of cadmium in 66 samples were less than the reporting level of $1 \mu \mathrm{g} / \mathrm{L}$. Two samples contained concentrations of $1 \mu \mathrm{g} / \mathrm{L}$, each (table 5 ).

Chromium.-Concentrations of chromium in 68 samples ranged from 2 to $48 \mu \mathrm{g} / \mathrm{L}$ and were distributed about median and mean concentrations of 8 and $9 \mu \mathrm{g} / \mathrm{L}$, respectively (table 6 ).

Copper-Concentrations of copper in 68 samples ranged from less than the reporting level of 1 to $16 \mu \mathrm{g} / \mathrm{L}$. The median and mean concentrations of 67 samples were 2 and $3 \mu \mathrm{g} / \mathrm{L}$, respectively (table 6).

Iron.- Concentrations of iron in 69 samples ranged from less than the reporting level of 10 to $9,700 \mu \mathrm{g} / \mathrm{L}$. The median and mean concentrations of 62 samples were 70 and $430 \mu \mathrm{g} / \mathrm{L}$, respectively (table 6).

Lead.-Concentrations of lead in 68 samples ranged from less than the reporting level of 1 to $8 \mu \mathrm{g} / \mathrm{L}$. The median and mean concentrations of 62 samples were 2 and $2 \mu \mathrm{g} / \mathrm{L}$, respectively (table 6 ).

Manganese.-Concentrations of manganese in 69 samples ranged from less than the reporting level of 10 to $200 \mu \mathrm{g} / \mathrm{L}$. The median and mean concentrations of 16 samples were 20 and $30 \mu \mathrm{g} / \mathrm{L}$, respectively (table 6).

Mercury.-Concentrations of mercury in 65 samples were less than the reporting level of 0.1 $\mu \mathrm{g} / \mathrm{L}$. The remaining four samples had concentrations of $0.1 \mu \mathrm{g} / \mathrm{L}$ (table 5).

Nickel-Concentrations of nickel in 68 samples ranged from less than the reporting level of 1 to $31 \mu \mathrm{g} / \mathrm{L}$. The median and mean concentrations of 52 samples were 2 and $3 \mu \mathrm{g} / \mathrm{L}$, respectively (table 6).

Selenium.-Concentrations of selenium in 69 samples ranged from less than the reporting level of 1 to $3 \mu \mathrm{g} / \mathrm{L}$. The median and mean concentrations of 59 samples were 1 and $1 \mu \mathrm{g} / \mathrm{L}$, respectively (table 6).

Silver-Concentrations of silver in 69 samples were less than the reporting level of $1 \mu \mathrm{g} / \mathrm{L}$ (table 5).

Zinc.-Concentrations of zinc in 69 samples ranged from less than the reporting level of 10 to 190 $\mu \mathrm{g} / \mathrm{L}$. The median and mean concentrations of 41 samples were $9(0$ and $80 \mu \mathrm{g} / \mathrm{L}$, respectively (table 6). 


\section{NUTRIENTS, ORGANIC CARBON, PHENOLS, AND TURBIDITY}

Water samples were analyzed for concentrations of dissolved ammonia as nitrogen, ammonia plus organic nitrogen as nitrogen, nitrite as nitrogen, nitrite plus nitrate as nitrogen, and orthophosphate as phosphorus (table 8). Samples were also analyzed for concentrations of total organic carbon and total phenols and measured for turbidity (table 9). Statistical parameters for dissolved nutrients, total organic carbon, total phenols, anci turbidity by well are given in table 10 .

Ammonia-Concentrations of ammonia as nitrogen in 33 samples ranged from less than the reporting level of 0.01 to $0.03 \mathrm{mg} / \mathrm{L}$. The median and mean concentrations of 12 samples were 0.02 and $0.02 \mathrm{mg} / \mathrm{L}$, respectively (table 10 ).

Ammonia plus organic nitrogen.-Concentrations of ammonia plus organic nitrogen as nitrogen in 36 samples ranged from less than the reporting level of 0.2 to $1.2 \mathrm{mg} / \mathrm{L}$. The median and mean concentrations of 22 samples were 0.4 and $0.4 \mathrm{mg} / \mathrm{L}$, respectively (table 10$)$ ).

Nitrite-Concentrations of nitrite as nitrogen in 68 samples were less than the reporting level of $0.01 \mathrm{mg} / \mathrm{L}$. One sample from USGS 12 (2/7/91) contained a concentration of $0.02 \mathrm{mg} / \mathrm{L}$ (table 8).

Nitrite plus nitrate.-Concentrations of nitrite plus nitrate as nitrogen in 69 samples ranged from 0.30 to $16 \mathrm{mg} / \mathrm{L}$ and were clistributed about median and mean concentrations of 1.7 and $2.0 \mathrm{mg} / \mathrm{L}$, respectively (table 1() ).

Orthophosphate.-Concentrations of orthophosphate as phosphorous in 36 samples ranged from less than the reporting level of 0.01 to $0.04 \mathrm{mg} / \mathrm{L}$. The median and mean concentrations of 24 samples were 0.02 and $0.02 \mathrm{mg} / \mathrm{L}$, respectively (table 10$)$.

Organic carbon.-Concentrations of organic carbon in 69 samples ranged from less than the reporting level of 0.1 to $2.2 \mathrm{mg} / \mathrm{L}$. The median and mean concentrations of 67 samples were 0.3 and $0.4 \mathrm{mg} / \mathrm{L}$, respectively (table 10$)$.

Phenols.- Concentrations of phenols in 69 samples ranged from less than the reporting level of 1 to $8 \mu \mathrm{g} / \mathrm{L}$. The median and mean concentrations of 52 samples were 2 and $3 \mu \mathrm{g} / \mathrm{L}$, respectively (table $10)$.

Turbidity.-Measurements of turbidity in 69 samples ranged from 0.2 to 59 nephelometric turbidity units (NTU) and were distributed about median and mean measurements of 0.4 and 1.7 NTU, respectively (table 10 ). 


\section{EXTRACTABLE ACID AND BASE/NEUTRAL ORGANIC COMPOUNDS}

Water samples were analyzed by the NWQL for 54 extractable acid and base/neutral organic compounds (table 11). Concentrations of compounds that are larger than the reporting level (table 11) are listed in table 12. Compounds in table 12 that are not listed in table 11 are tentatively identified organic compounds (TIOC's 1 ).

\section{PESTICIDES}

Concentrations of 15 organochlorine insecticides, gross polychlorinated biphenyls, gross polychlorinated naphthalenes and 4 chlorophenoxy acid herbicides (table 13) were determined by the NWQL. Pesticides were not detected in any wells at concentrations larger than the reporting levels.

\section{GROSS ALPHA- AND GROSS BETA-PARTICLE RADIOACTIVITY}

Concentrations of both dissolved and suspended gross alpha- and gross beta-particle radioactivity were determined for the 69 samples using a residue procedure. Concentrations of gross alpha-particle radioactivity are listed in table 14; statistical parameters are given in table 15 . Concentrations of gross beta-particle radioactivity are listed in table 16; statistical parameters are given in table 17.

Gross alpha-particle radioactivity-Cross alpha-particle radioactivity is a measure of the total radioactivity given off as alpha particles during the radioactive decay process. For convenience, laboratories report the radioactivity as if it were all given off by one radionuclide. In this report, concentrations are reported two ways: as natural uranium in micrograms per liter and as thorium-230) in picocuries per liter.

Gross alpha-particle radioactivity was measured in both the dissolved and suspended fractions of the water samples from selected wells at the NRF and vicinity (table 14). All of the samples contained concentrations of gross alpha-particle radioactivity in the dissolved fraction larger than the reporting level of $3 \mathrm{~s}$. Concentrations of uranium ranged from $1.67 \pm() .424$ to $5.17 \pm(1.70 \mu \mathrm{g} / \mathrm{L}$, and were distributed about median and mean concentrations of 3.7()$\pm() .64$ and $3.65 \pm(1.09 \mu \mathrm{g} / \mathrm{L}$, respectively (table 15). Concentrations of thorium-230) ranged from $1 .() 4 \pm() .27()$ to $3.72 \pm() .5()) \mathrm{pCi} / \mathrm{L}$, and were distributed about median and mean concentrations of $2.55 \pm 0.438$ and 2.5()$\pm 0.065 \mathrm{pCi} / \mathrm{L}$, respectively.

Two of the samples contained concentrations of gross alpha-particle radioactivity in the suspended fraction-reported as uranium-larger than the reporting level. A sample from USGS 15, collected

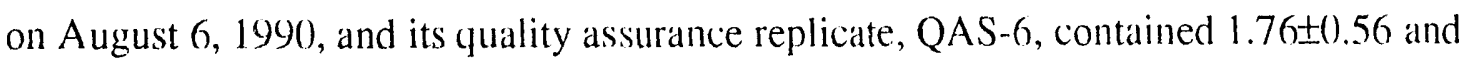
$9.10 \pm 3.0() \mu \mathrm{g} / \mathrm{L}$, respectively (table 14$)$. The reason for the discrepancy is unknown. Concentrations

\footnotetext{
'Data for TIOC's in this report are based on comparison of sample spectra with library spectra followed by visual examination by gas chromatography and mass spectrometry analysts. TIOC data have not been confirmed by direct comparison with reference standards. Therefore, TIOC identification is tentative, and reported concentrations are semiquantitative.
} 
of uranium (suspended) were distributed about median and mean concentrations of $-(0.018 \pm() .084$ and $0.141 \pm 0.135 \mu \mathrm{g} / \mathrm{L}$, respectively. One of the samples contained a concentration of gross alpha-particle radioactivity in the suspended fraction-reported as thorium-230-larger than the reporting level. A sample from USGS 15, collected on August 6, 1990), contained 2.20 $\pm 0.71 \mathrm{pCi} / \mathrm{L}$ (table 14). The reason for the discrepancy is unknown. Concentrations of thorium-230 (suspended) were distributed about median and mean concentrations of $-(0.01 \pm(0.046$ and $0.128 \pm(0.110 \mathrm{pCi} / \mathrm{L}$, respectively (table $15)$.

Gross beta-particle radioactivity - Gross beta-particle radioactivity is a measure of the total radioactivity given off as beta particles during the radioactive decay process. For convenience, laboratories report the radioactivity as if it wei $i$ all given off by one radionuclide or a chemically similar pair of radionuclides in equilibrium. In this report, concentrations are reported two ways: as strontium-90 in equilibrium with yttrium- $90\left(\mathrm{Sr}^{90} / \mathrm{Y}^{90}\right)$ in picocuries per liter, and as cesium-137 in picocuries per liter.

Gross beta-particle radioactivity was measured in both the dissolved and suspended fractions of the water samples from selected wells at the NRF and vicinity (table 16). All of the water samples contained concentrations of gross beta-particle radioactivity in the dissolved fraction larger than the reporting level. Concentrations of $\mathrm{Sr}^{90} / \mathrm{Y}^{90}$ ranged from $1.42 \pm() .282$ to $4.32 \pm() .56 \mathrm{pCi} / \mathrm{L}$, and were distributed about median and mean concentrations of $2.79 \pm 0.62$ and $2.82 \pm 0.08 \mathrm{pCi} / \mathrm{L}$, respectively (table 17). Concentrations of cesium-137 ranged from $1.95 \pm 0.411$ to $5.76 \pm 0.75 \mathrm{pCi} / \mathrm{L}$ and were distributed about median and mean concentrations of $3.78 \pm 0.73$ and $3.77 \pm 0.10 \mathrm{pCi} / \mathrm{L}$, respectively.

Three of the samples contained concentrations of gross beta-particle radioactivity in the suspended fraction-reported as $\mathrm{Sr}^{9(0)} / \mathrm{Y}^{90}$ - larger than the reporting level. A sample from USGS 12 collected on April 11, 1991 and a sample from USGS 15 collected on August 6,199() and its quality assurance replicate, QAS-6, contained concentrations of $(0.621 \pm(1) .200), 1.68 \pm(0.330$, and $5.74 \pm(0.80 \mathrm{pCi} / \mathrm{L}$, respectively. The reason for the discrepancy is unknown. The concentrations of $\mathrm{Sr}^{90} / \mathrm{Y}^{90}$ (suspended) in the samples were distributed about median and mean concentrations of $0.193 \pm() .228$ and $0.312 \pm 0.086 \mathrm{pCi} / \mathrm{L}$, respectively. Three of the samples contained concentrations of gross beta-particle radioactivity in the suspended fraction-reported as cesium-137-larger than the reporting level. A sample from USGS 12 collected on April 11, 1991 and a sample from USGS 15 collected on August 6, 1990 and its quality assurance replicate, QAS-6, contained concentrations of $0.639 \pm 0.205$, $2.12 \pm 0.414$, and $7.4(1) \pm 1.02 \mathrm{pCi} / \mathrm{L}$, respectively. The reason for the discrepancy is unknown. The concentrations of cesium-137 (suspended) in the samples were distributed about median and mean concentrations of $0.211 \pm 0.268$ and $(0.359 \pm() .118 \mathrm{pCi} / \mathrm{L}$, respectively. 


\section{SELECTED RADIUM ISOTOPES}

Radium-226 and radium-228 are naturally occurring decay products of uranium-238 and thorium232, respectively. Concentrations of radium-226 for 68 samples (table 18 ) were determined by using a radon emanation procedure; concentrations of radium-228 for the samples (table 18) were determined by using a separation and beta counting procedure. Statistical parameters by well for radium-226 and radium-228 are given in table 19.

Concentrations of radium-226 in 63 of the 68 water samples from the wells at the NRF and vicinity were larger than the reporting level. Concentrations ranged from $-(0.0(1) 2 \pm(0.0() 4$ to $(0.975 \pm(0.0)(08 \mathrm{pCi} / \mathrm{L}$ and were distributed about median and mean concentrations of $0.079 \pm 0.008$ and $0.084 \pm(0.015 \mathrm{pCi} / \mathrm{L}$, respectively (table 19). Concentrations of radium-228 in 5 of the 69 samples were larger than the reporting level. Concentrations ranged from -() $.133 \pm() .2()()$ to () $.545 \pm() .176 \mathrm{pCi} / \mathrm{L}$ and were distributed about median and mean concentrations of $(0.157 \pm() .(20)$ and $(0.212 \pm() .019 \mathrm{pCi} / \mathrm{L}$, respectively (table 19).

\section{MISCELLANEOUS DATA}

As part of a special request, concentrations of 36 purgeable organic compounds (table 20) in 4 samples from 4 wells were determined by the NWQL using a method that conforms to U.S. Environmental Protection Agency method 524.2 (Pritt and Jones, 1989; M.P. Schroeder, USGS, written commun., 1991). Samples were collected from NRF-1 (December 6, 199()), NRF-2 (December 5, 199()), NRF-3 (December 6, 199()), and NRF-4 (December 5, 199()). No purgeable organic compounds were present in any sample at concentrations larger than the reporting level of ().2 g/L. TIOC's were not identified in any of the samples.

Uranium is a widely distributed element that has three naturally occurring radioactive isotopes: uranium-238, uranium-235, and uranium-234. These isotopes undergo a complex series of radioactive decaly that ultimately results in their conversion to stable isotopes of lead (Haglund, 1972, p. 1216). Total uranium is a measurement of the combined concentrations of these three isotopes. One sample from NRF-3 (March 21, 199()) was analyzed for dissolved total uranium and contained a concentration of $2.51 \pm(1) .4() 6 \mu \mathrm{g} / \mathrm{L}$.

Water samples were collected from the Central Facilities Area (CFA) water supply and the NRF water supply for comparison. The samples were analyzed for 54 extractable acid and base/neutral organic compounds (table 11), 36 purgeable organic compounds (table 2()), and 12 total recoverable trace elements (table 21). No extractable acid and base/neutral organic compounds were present in either sample at concentrations larger than reporting levels. The CFA water supply contained 2.8 $\mu \mathrm{g} / \mathrm{L}$ of bromoform, $0.7 \mu \mathrm{g} / \mathrm{L}$ of dibromochloromethane, and $(1.3 \mu \mathrm{g} / \mathrm{L}$ of trichloroethylene. The NRF water supply contained $(0.4 \mu \mathrm{g} / \mathrm{L}$ of bromoform. A trip blank contained $0.2 \mu \mathrm{g} / \mathrm{L}$ of ethylbenzene, 1.0 $\mu \mathrm{g} / \mathrm{L}$ of dichloromethane, $1.2 \mu \mathrm{g} / \mathrm{L}$ of total xylenes, $0.2 \mu \mathrm{g} / \mathrm{L}$ of $1,3,5$-trimethylbenzene, and 
0.8 $\mu \mathrm{g} / \mathrm{L}$ of 1,2,4-irimethylbenzene. Concentrations of arsenic, barium, cadmium, chromium, copper, iron, lead, manganese, nickel, selenium, silver, and zinc in the CFA water supply and the NRF water supply are given in table 21 .

\section{SUMMARY}

The USGS, in response to a request from the U.S. Department of Energy's Pittsburgh Naval Reactors Office, Idaho Branch Office, sampled 12 wells as part of a long-term project to monitor water quality of the Snake River Plain aquifer in the vicinity of the NRF, INEL, Idaho. Water samples were collected and analyzed for manmade contaminants and naturally occurring constituents. Sixty samples were collected from eight ground-water monitoring wells and four production wells. Ten quality assurance samples also were collected and analyzed. The ranges of concentrations of dissolved anions and total sodium follow: bromide, from less than the reporting level to $0.34 \mathrm{mg} / \mathrm{L}$; chloricle, 4.8 to $140 \mathrm{mg} / \mathrm{L}$; fluoride, from less than the reporting level to $0.7 \mathrm{mg} / \mathrm{L}$; sodium, 5.7 to 20 $\mathrm{mg} / \mathrm{L}$, and sulfate, 15 to $160 \mathrm{mg} / \mathrm{L}$.

Samples were analyzed for 13 trace elements. Concentrations of cadmium, mercury, and silver were either less than or equal to the laboratory reporting levels. Concentrations of barium, copper, iron, lead, manganese, nickel, selenium, and zinc ranged from less than the laboratory reporting levels to 20()$, 16,9,70(), 8,200,31,3$, and 19()$\mu \mathrm{g} / \mathrm{L}$, respectively. The respective ranges of concentrations for arsenic and chromium were 1 to $12 \mu \mathrm{g} / \mathrm{L}$ and 2 to $48 \mu \mathrm{g} / \mathrm{L}$. The predominant category of nitrogenbearing compounds in these samples was nitrite plus nitrate, which ranged in concentration from ().30 to $16 \mathrm{mg} / \mathrm{L}$, expressed as nitrogen.

Concentrations of total organic carbon ranged from less than $(0.1$ to $2.2 \mathrm{mg} / \mathrm{L}$. Total phenols in 52 of 69 samples ranged from 1 to $8 \mu \mathrm{g} / \mathrm{L}$. Turbidity measurements ranged from 0.2 to $59 \mathrm{NTU}$. One or more extractable acid and base/neutral organic compounds were present in water from 16 of 69 samples. Pesticides were not detected in any wells at concentrations larger than the reporting level.

Concentrations of dissolved gross alpha- and gross beta-particle radioactivity in all samples exceeded the reporting level. Most of the samples contained concentrations of suspended gross alphaand gross beta-particle radioactivity less than the reporting level. Radium-226 concentrations were larger than the reporting level in 63 of 68 samples; radium-228 concentrations were larger than the reporting level in 5 of the 69 samples.

\section{SELECTED REFERENCES}

Claassen, H.C., 1982, Guidelines and techniques for obtaining water samples that accurately represent the water chemistry of an ayuifer: U.S. Geological Survey Open-File Report 82-1024, 49 p. 
Currie, L.A., 1984, Lower limit of detection-Definition and elaboration of a proposed position for radiological effluent and environmental measurements: U.S. Nuclear Regulatory Commission NUREG/CR-4(1)77, 139 p.

Fishman, M.J., and Friedman, L.C., eds., 1989, Methods for determination of inorganic substances in water and fluvial sediments: U.S. Geological Survey Technigues of Watter-Resources Investigations, book 5 , chap. A1, 545 p.

Friedman, L.C., and Erdmann, D.E., 1982, Quality assurance practices for the chemical and biological analyses of water and fluvial sediments: U.S. Cieological Survey Techniques of Water-Resources Investigations, book 5, chap. A6, $181 \mathrm{p}$.

Goerlitz, D.F., and Brown, Eugene, 1972, Methods for analysis of organic substances in water: U.S. Geological Survey Techniques of Water-Resources Investigaltions, book 5, chap. A3, 4() p.

Haglund, D.S., 1972, Uranium--Element and geochemistry, in Fairbridge, R.W., ed., The encyclopedia of geochemistry and environmental sciences: Stroudsbery, Pa., Dowden, Hutchinson, and Ross, p. 1,215-1,222.

Hardy, M.A., Leahy, P.P., and Alky, W.M., 1989, Well installation and documentation, and groundwater sampling protocols for the pilot national water-quality assessment program: U.S. Geological Survey Open-File Report 89-396, 36 p.

Iman, R.L., and Conover, W.J., 1983, A modern approach to statistics: New York, John Wiley \& Sons, Inc., 497 p.

Jones, B.E., 1987, Quality control manual of the U.S. Geologsical Survey's National Water Quality Laboratory: U.S. Geological Survey Open-File Report 87-457, 17 p.

Knobel, L.L., Bartholomay, R.C., Wegner, S.J., and Edwards, D.D., 1992, Chemical constituents in water from wells in the vicinity of the Naval Reactors Facility, Idaho National Engineering Laboratory, Idaho, 1989-9): U.S. Geological Survey Open-File Report 92-156 (DOE/ID$221(1) 3), 38 \mathrm{p}$.

Mann, L.J., 1986, Hydraulic properties of rock units and chemical yuality of water for INEL-1--a 1(1,365-foot deep test hole drilled at the Idaho National Engineering Laboratory, Idaho: U.S. Geological Survey Water-Resources Investigations Report 8(7-4(12) (DOE/ID-22(17)), 23 p.

-..- 1989, Tritium concentrations in flow from selected springs that discharge to the Snake River, Twin Falls-Hagerman area, Idaho: U.S. Geological Survey Water-Resources Investigations Report 89-4156 (DOE/ID-22()84), 2() p.

Orr, B.R., and Cecil, L.D., 1991, Hydrologic conditions and distribution of selected chemical constituents in water, Snake River Plain aquifer, Idaho National Engineering Laboratory, Idaho, 1986 to 1988: U.S. Geological Survey Waller-Resources Investigations Report 91-4(147 (DOE/ID-22(19), $56 \mathrm{p}$. 
Pritt, J.W., 1989, Quality assurance of sample containers and preservatives at the U.S. Geological Survey National Water Quality Laboratory, in Pederson, G.L. and Smith, M.M. compilers, U.S. Geological Survey Second National Symposium on Water Quality-Abstracts of the Technical Sessions, Orlando, Fla., November 12-17, 1989: U.S. Geological Survey Open-File Report 89$4(0)$, p. 75.

Pritt, Jeffrey, and Jones, B.E., eds., 1989, 1990 National Water Quality Laboratory services catalog: U.S. Geological Survey Open-File Report 89-386, unnumbered.

Stevens, H.H., Jr., Ficke, J.F., and Smoot, G.F., 1975, Water temperature--influential factors, field measurement, and data presentation: U.S. Geological Survey Techniques of Water-Resources Investigations, book 5, chap. D1, 65 p.

Thatcher, L.L., Janzer, V.J., and Edwards, K.W., 1977, Methods for deţermination of radioactive substances in water and fluvial sediments: U.S. Geological Survey Techniques of WaterResources Investigations, book 5, chap. A5, 95 p.

U.S. Environmental Protection Agency, 1989, Protection of Environment, Code of Federal

Regulations 40: Office of the Federal Register, National Archives and Records Administration, pts. 190 to $299,1,(027 \mathrm{p}$.

U.S. Geological Survey, 1985, National water summary, 1984--Hydrologic events, selected waterquality trends, and ground-water resources: U.S. Geological Survey Water-Supply Paper 2275, $467 \mathrm{p}$.

Wegner, S.J., 1989, Selected water quality assurance data for water samples collected by the U.S. Geological Survey, Idaho National Engineering Laboratory, Idaho, 1980) to 1988: U.S. Geological Survey Water-Resources Investigations Report 89-4168 (DOE/ID-22()85), 91 p.

Wershaw, R.L., Fishman, M.J., Crabbe, R.R., and Lowe, L.E., 1987, Method for the determination of organic substances in water and fluvial sediments: U.S. Geological Survey Techniques of Water-Resources Investigations, book 5, chap. A3, 80 p.

Wood, W.W., 1981, Guidelines for collection and field analysis of ground-water samples for selected unstable constituents: U.S. Geological Survey Techniques of Water-Resources Investigations, book 1, chap. D2, 24 p. 
Table 1.-Containers and preservatives used for water samples, Naval Reactors Facility and vicinity

Analyses were performed by the U.S. Geological Survey's National Water Quality Laboratory. mL, milliliter; ${ }^{\circ} \mathrm{C}$, degrees Celsius; $\mathrm{L}$, liter: $\mathrm{HNO}_{3}$, nitric acid; $\mathrm{K}_{2} \mathrm{Cr}_{2} \mathrm{O}_{7}$, potarsium dichromate; $\mathrm{HgCl}_{2}$, mercuric chloride; $\mathrm{NaCl}$, sodium chloride; $\mathrm{H}_{3} \mathrm{PO}_{4}$, phosphoric acid; $\mathrm{CuSO}_{4}$, copper sulfate; $\mathrm{HCl}$, hydrochloric acid. Samples were shipped by overnight-delivery mail]

\begin{tabular}{|c|c|c|c|c|c|}
\hline \multirow{2}{*}{$\begin{array}{l}\text { Type of } \\
\text { constituent }\end{array}$} & \multicolumn{2}{|c|}{ Container } & \multicolumn{2}{|c|}{ Preservative } & \multirow{2}{*}{$\begin{array}{l}\text { Other } \\
\text { treatment }\end{array}$} \\
\hline & Type & Size & Type & Quantity & \\
\hline Anions & Polyethylene & $250) \mathrm{mL}$ & None & None & Filter \\
\hline Sodium & $\begin{array}{l}\text { Polyethylene, } \\
\text { acid-rinsed }\end{array}$ & 25() $\mathrm{mL}$ & $\mathrm{HNO}_{3}$ & $1 \mathrm{~mL}$ & None \\
\hline \multirow{2}{*}{$\begin{array}{l}\text { Trace elements, } \\
\text { total recoverable }\end{array}$} & Polyethylene, & $50)(1 \mathrm{~mL}$ & $\mathrm{HNO}_{3}$ & $2 \mathrm{~mL}$ & None \\
\hline & $\begin{array}{l}\text { Polyethylene, } \\
\text { acid-rinsed }\end{array}$ & $250 \mathrm{~mL}$ & $\mathrm{HNO}_{3}$ & $1 \mathrm{~mL}$ & None \\
\hline Mercury, total & $\begin{array}{l}\text { Giass, } \\
\text { acid-rinsed }\end{array}$ & $250 \mathrm{~mL}$ & $\begin{array}{c}\mathrm{K}_{2} \mathrm{Cr}_{2} \mathrm{O}_{7} / \\
\mathrm{HNO}_{3}\end{array}$ & $10 \mathrm{~mL}$ & None \\
\hline Nutrients, total & $\begin{array}{l}\text { Polyethylene, } \\
\text { brown }\end{array}$ & 25() $\mathrm{mL}$ & $\begin{array}{l}\mathrm{HgCl}_{2} / \\
\mathrm{NaCl}\end{array}$ & $1 \mathrm{~mL}$ & Chill $4^{\circ} \mathrm{C}$ \\
\hline $\begin{array}{l}\text { Total organic } \\
\text { carbon }\end{array}$ & Glass, baked & $125 \mathrm{~mL}$ & None & None & Chill $4^{\circ} \mathrm{C}$ \\
\hline Phenols, total & Gilass, biked & $1 \mathrm{~L}$ & $\begin{array}{r}\mathrm{H}_{3} \mathrm{PO}_{4} / \\
\mathrm{CuSO}_{4}\end{array}$ & $10 \mathrm{~mL}$ & Chill $4^{\circ} \mathrm{C}$ \\
\hline Turbidity & Polyethylene & $125 \mathrm{~mL}$ & None & None & None \\
\hline $\begin{array}{l}\text { Extractable acid } \\
\text { and base/neutral } \\
\text { organic compounds }\end{array}$ & Glisss, baked & $1 \mathrm{~L}$ & None & None & Chill 45 \\
\hline Pesticides & Glass, baked & 11. & None & None & Chill $4^{\circ} \mathrm{C}$ \\
\hline $\begin{array}{l}\text { Gross alpha } \\
\text { and beta }\end{array}$ & $\begin{array}{l}\text { Polyethylene, } \\
\text { acid-rinsed }\end{array}$ & $1 \mathrm{~L}$ & None & None & None \\
\hline
\end{tabular}


Table 1.-Containers and preservatives used for water samples, Naval Reactors Facility and vicinity-Continued

\begin{tabular}{|c|c|c|c|c|c|}
\hline \multirow{2}{*}{$\begin{array}{l}\text { Type of } \\
\text { constituent }\end{array}$} & \multicolumn{2}{|c|}{ Container } & \multicolumn{2}{|c|}{ Preservative } & \multirow{2}{*}{$\begin{array}{c}\text { Other } \\
\text { treatment }\end{array}$} \\
\hline & Type & Size & Type & Quantity & \\
\hline Radium-226 & $\begin{array}{l}\text { Polyethylene, } \\
\text { acid-rinsed }\end{array}$ & $1 \mathrm{~L}$ & $\mathrm{HCl}$ & $5 \mathrm{~mL}$ & Filter \\
\hline Radium-228 & $\begin{array}{l}\text { Polyethylene, } \\
\text { acid-rinsed }\end{array}$ & $1 \mathrm{~L}$ & $\mathrm{HCl}$ & $5 \mathrm{~mL}$ & Filter \\
\hline $\begin{array}{l}\text { Purgeable organic } \\
\text { compounds }\end{array}$ & Glass, baked & $40 \mathrm{~mL}$ & None & None & Chill $4^{\circ} \mathrm{C}$ \\
\hline
\end{tabular}


Tiable 2.-Results of field measurements for $\mathrm{pH}$, specific conductance, and temperature of water, Naval Reactors Fac "' $"$ and vicinity

IUnits: $\mathrm{pH}$, negative base-10 logarithm of hydrogen ion activity in moles per litei; specific conductance, microsiemens per centimeter at $25^{\circ} \mathrm{C}$ (degrees Celsius); temperature, ${ }^{\circ} \mathrm{C}$. See figure 2 for lncation of wells. QAS, quality assuranc sample (see Quality Assurance section in text for explanation), RESL, Radiological and Environmental Sciences Laboratory. Values for field measurements for each pair of primary and replicate samples are the same]

\begin{tabular}{|c|c|c|c|c|c|c|}
\hline $\begin{array}{l}\text { Well } \\
\text { identifier }\end{array}$ & $\begin{array}{c}\text { Date } \\
\text { sampled } \\
(\mathrm{m} / \mathrm{d} / \mathrm{y})\end{array}$ & Time & $\mathrm{pH}$ & $\begin{array}{l}\text { Specific } \\
\text { conduct- } \\
\text { ance }\end{array}$ & $\begin{array}{l}\text { Temper- } \\
\text { ature }\end{array}$ & Remarks \\
\hline QAS-8 & $11 / 2 / 90$ & 1100 & 6.2 & 18.2 & $24 .()$ & $\begin{array}{l}\text { blank, deionized } \\
\text { water from RESL }\end{array}$ \\
\hline \multirow[t]{5}{*}{ NRF-1 } & $3 / 21 / 90$ & 1235 & 8.0 & 555 & 12.5 & \\
\hline & $6 / 19 / 90$ & 1345 & 8.0 & 580 & 12.0 & \\
\hline & $8 / 7 / 90$ & 1245 & 7.7 & 555 & 12.5 & \\
\hline & $1(1) / 2 / 90$ & 1405 & 7.8 & 550 & 12.5 & \\
\hline & $12 / 6 / 90$ & 1030 & 8.0 & 560 & 11.0 & \\
\hline \multirow[t]{6}{*}{ NRF-2 } & $3 / 21 / 90$ & 1130 & 7.9 & 610 & 13.0 & \\
\hline & $3 / 21 / 90$ & 1000 & 7.9 & 610 & $13 .()$ & QAS-2, replicate \\
\hline & $6 / 19 / 90$ & 1115 & 7.9 & 650 & 12.0 & \\
\hline & $8 / 7 / 90$ & 1110 & 7.8 & 625 & 12.5 & \\
\hline & $10 / 2 / 90$ & 1255 & 7.8 & 685 & 13.0 & \\
\hline & $12 / 5 / 90$ & 1010 & 8.2 & 670 & 11.5 & \\
\hline \multirow[t]{5}{*}{ NRF-3 } & $3 / 21 / 90$ & 1410 & 7.9 & 550 & 11.5 & \\
\hline & $6 / 19 / 90$ & 1325 & 8.0 & 570 & 12.0 & \\
\hline & $8 / 7 / 90$ & 1315 & 7.8 & 570 & 12.0 & \\
\hline & $10 / 2 / 90$ & 1330 & 7.7 & 550 & 12.0 & \\
\hline & $12 / 6 / 90$ & 1150 & 8.2 & 550 & 10.5 & \\
\hline \multirow[t]{6}{*}{ NRF-4 } & $6 / 19 / 90$ & 0940 & 7.9 & 610 & 12.0 & \\
\hline & $8 / 7 / 90$ & 1000 & 7.8 & 595 & 13.0 & \\
\hline & $10 / 2 / 90$ & 1125 & 7.7 & 580 & 12.5 & \\
\hline & $12 / 5 / 90$ & 1145 & 8.0 & 600 & 12.0 & \\
\hline & $2 / 7 / 91$ & 1045 & 7.8 & $6(15$ & 11.5 & \\
\hline & $2 / 7.91$ & 1400 & 7.8 & 605 & 11.5 & QAS-12, replicate \\
\hline \multirow[t]{5}{*}{ USGS 12} & $8 / 1.90$ & 1515 & 7.9 & 595 & 12.5 & \\
\hline & $10110 / 90$ & 1150 & 7.8 & 545 & 12.0 & \\
\hline & $1211 / 90$ & 1245 & 7.9 & 552 & 12.0 & \\
\hline & $2 / 91$ & 1425 & 7.8 & 600 & 13.0 & \\
\hline & $4 / 11 / 91$ & 1125 & 7.8 & 560 & $14 .()$ & \\
\hline
\end{tabular}


Table 2.- Results of fỉeli measurements for $\mathrm{pH}$, specific conductance, and temperature of water, Naval Reactors Facility and vicinity-Continued

\begin{tabular}{|c|c|c|c|c|c|c|}
\hline $\begin{array}{c}\text { Well } \\
\text { identifier }\end{array}$ & $\begin{array}{l}\text { Date } \\
\text { sampled } \\
(\mathrm{m} / \mathrm{d} / \mathrm{y})\end{array}$ & Time & $\mathrm{pH}$ & $\begin{array}{l}\text { Specific } \\
\text { conduct- } \\
\text { ance }\end{array}$ & $\begin{array}{l}\text { Temper- } \\
\text { ature }\end{array}$ & Remarks \\
\hline \multirow[t]{6}{*}{ USGS 15} & $8 / 6 / 90$ & 1145 & 7.8 & 590 & 11.5 & \multirow{6}{*}{ QAS-6, replicate } \\
\hline & $8 / 6 / 90$ & 1200 & 7.8 & 590 & 11.5 & \\
\hline & $10 / 9 / 90$ & 1440 & 7.8 & 450 & 11.5 & \\
\hline & $12 / 13 / 90$ & 1450 & 8.2 & 327 & 12.0 & \\
\hline & $2 / 11 / 91$ & 1450 & 8.0 & 328 & 12.0 & \\
\hline & $4 / 12 / 91$ & 1745 & 8.1 & 301 & 11.5 & \\
\hline \multirow[t]{5}{*}{ USGS 17} & $3 / 20 / 90$ & 1130 & 8.2 & 291 & 14.0 & \\
\hline & $6 / 7 / 90$ & 0,940 & 8.2 & 298 & 13.0 & \\
\hline & $8 / 2 / 90$ & 1055 & 8.2 & 305 & 13.5 & \\
\hline & $10 / 10 / 90$ & $1+50$ & 8.2 & 292 & 13.5 & \\
\hline & $12 / 10 / 90$ & 1140 & 8.2 & 295 & 13.0 & \\
\hline \multirow[t]{7}{*}{ USGS 97} & $3 / 19 / 90$ & 1320 & 8.0 & 570 & 12.0 & \\
\hline & $6 / 7 / 90$ & 1150 & 7.8 & 585 & 12.0 & \\
\hline & $6 / 7 / 90$ & 1200 & 7.8 & 585 & 12.0 & \multirow[t]{4}{*}{ QAS-3, replicate } \\
\hline & $8 / 1 / 90$ & 1245 & 7.9 & 585 & 12.0 & \\
\hline & $10 / 4 / 90$ & 1055 & 7.4 & 560 & 12.0 & \\
\hline & $12 / 7 / 90$ & 1330 & 7.9 & 595 & 11.5 & \\
\hline & $12 / 7 / 90$ & 1300 & 7.9 & 595 & 11.5 & QAS-10, replicate \\
\hline \multirow[t]{6}{*}{ USGS 98} & $3 / 19 / 90$ & 1000 & 8.0 & 406 & 12.5 & \multirow{6}{*}{ QAS-5, replicate } \\
\hline & $6 / 5 / 90$ & 1000 & 8.0 & 425 & 12.0 & \\
\hline & $7 / 30 / 90$ & 1055 & 8.0 & 420 & 12.5 & \\
\hline & $7 / 30 / 90$ & 1200 & 8.0 & 420 & 12.5 & \\
\hline & $10 / 3 / 90$ & 1015 & 7.8 & 392 & 12.0 & \\
\hline & $12 / 7 / 90$ & 1005 & 8.1 & 405 & 12.0 & \\
\hline \multirow[t]{6}{*}{ USGS 99} & $3 / 20 / 90$ & 0925 & 7.9 & 511 & 12.5 & \multirow{6}{*}{ QAS-7, replicate } \\
\hline & $6 / 5 / 90$ & 1350 & 7.9 & 520 & 12.0 & \\
\hline & $8 / 1 / 90$ & 1010 & 8.0 & 530 & 12.0 & \\
\hline & $10 / 3 / 90$ & 1335 & 7.8 & 495 & 12.0 & \\
\hline & $10 / 3 / 90$ & 1330 & 7.8 & 495 & 12.0 & \\
\hline & $12 / 10 / 90$ & 1015 & 8.0 & 508 & 11.5 & \\
\hline
\end{tabular}


Table 2.- Results of field measurements for $\mathrm{pH}$, specific conductance, and temperature of water, Naval Reactors Facility and vicinity-Continued

\begin{tabular}{lllllll}
\hline $\begin{array}{l}\text { Well } \\
\text { identifier }\end{array}$ & $\begin{array}{l}\text { Date } \\
\text { sampled } \\
(\mathrm{m} / \mathrm{d} / \mathrm{y})\end{array}$ & Time & $\mathrm{pH}$ & $\begin{array}{c}\text { Specific } \\
\text { conduct- } \\
\text { ance }\end{array}$ & $\begin{array}{c}\text { Temper- } \\
\text { ature }\end{array}$ & Remarks \\
\hline \multirow{2}{*}{ USGS 102 } & $8 / 1 / 90$ & 1415 & 8.0 & 570 & 12.0 & \\
& $10 / 4 / 90$ & 1245 & 7.8 & 538 & 12.0 & \\
& $12 / 10 / 90$ & 1315 & 8.0 & 555 & 11.5 & QAS-11, replicate \\
& $12 / 10 / 90$ & 1230 & 8.0 & 555 & 11.5 & \\
& $2 / 7 / 91$ & 1035 & 8.0 & 550 & 11.5 & \\
Water Supply & $4 / 11 / 91$ & 1245 & 7.9 & 544 & 13.0 & \\
INEL-1 & & & & & & \\
& $3 / 19 / 90$ & 1210 & 7.9 & 772 & 12.0 & \\
& $6 / 5 / 90$ & 1215 & 7.9 & 795 & 12.0 & \\
& $7 / 30 / 90$ & 1315 & 7.9 & 800 & 12.5 & \\
& $10 / 3 / 90$ & 1210 & 7.7 & 765 & 12.0 & \\
& $12 / 7 / 90$ & 1145 & 7.9 & 760 & 12.0 & \\
& $12 / 7 / 90$ & 1100 & 7.9 & 760 & 12.0 & QAS-9, replicate \\
\hline
\end{tabular}


Table 3.-Concentrations of dissolved anions and total sodium in water, Naval Reactors Facility and vicinity

[Analyses were performed by the U.S. Geological Survey's National Water Quality Laboratory. Analytical results are in milligrams per liter. See figure 2 for location of wells. QAS, quality assurance sample (see Quality Assurance section in text for explanation); <, concentration is less than the indicated reporting level; SR, sample ruined]

\begin{tabular}{|c|c|c|c|c|c|c|}
\hline $\begin{array}{c}\text { Well } \\
\text { identifier }\end{array}$ & $\begin{array}{c}\text { Date } \\
\text { sampled } \\
(\mathrm{m} / \mathrm{d} / \mathrm{y})\end{array}$ & Bromide & Chloride & Fluoride & Sulfate & Sodium \\
\hline QAS-8 & $11 / 2 / 90$ & $<(0.01$ & $<0.1$ & $<0.1$ & $<1.0$ & 0.3 \\
\hline \multirow[t]{5}{*}{ NRF-1 } & $3 / 21 / 90$ & .06 & 33 & $<.1$ & 43 & 13 \\
\hline & $6 / 19 / 90$ & .07 & 33 & .3 & 36 & 13 \\
\hline & $8 / 7 / 90$ & .07 & 33 & .5 & 36 & 13 \\
\hline & $10 / 2 / 90$ & .07 & 34 & $<.1$ & 35 & 13 \\
\hline & $12 / 6 / 90$ & .06 & 33 & .2 & 37 & 13 \\
\hline NRF-2 & $3 / 21 / 90$ & .07 & 45 & $<.1$ & 52 & 17 \\
\hline \multirow[t]{5}{*}{ QAS-2 } & $3 / 21 / 90$ & .06 & 45 & $<.1$ & 51 & 17 \\
\hline & $6 / 19 / 90$ & .08 & 43 & .3 & 44 & 20 \\
\hline & $8 / 7 / 90$ & .08 & 46 & .5 & 44 & 18 \\
\hline & $10 / 2 / 90$ & .07 & 39 & $<.1$ & 39 & 17 \\
\hline & $12 / 5 / 90$ & .06 & 50 & .3 & 49 & 19 \\
\hline \multirow[t]{5}{*}{ NRF-3 } & $3 / 21 / 90$ & .06 & 30 & .1 & 35 & 13 \\
\hline & $6 / 19 / 90$ & .07 & 34 & .4 & 38 & 13 \\
\hline & $8 / 7 / 90$ & .07 & 32 & .6 & 35 & 14 \\
\hline & $10 / 2 / 90$ & .07 & 31 & $<.1$ & 34 & 12 \\
\hline & $12 / 6 / 90$ & .06 & 31 & .1 & 37 & 13 \\
\hline \multirow[t]{5}{*}{ NRF-4 } & $6 / 19 / 90$ & .05 & 42 & .3 & 43 & 18 \\
\hline & $8 / 7 / 90$ & .07 & 37 & .6 & 39 & 15 \\
\hline & $10 / 2 / 90$ & .08 & 41 & $<.1$ & 41 & 16 \\
\hline & $12 / 5 / 90$ & .06 & 42 & .2 & 47 & 16 \\
\hline & $2 / 7 / 91$ & .06 & 41 & .1 & 45 & 14 \\
\hline QAS-12 & $2 / 7 / 91$ & .07 & 40 & .2 & 38 & 16 \\
\hline \multirow[t]{5}{*}{ USGS 12} & $8 / 6 / 90$ & .08 & 32 & .4 & 32 & 10 \\
\hline & $10 / 10 / 90$ & .97 & 32 & .1 & 33 & 12 \\
\hline & $12 / 11 / 90$ & .06 & 35 & .2 & 35 & 12 \\
\hline & $2 / 7 / 91$ & .07 & 34 & .1 & 33 & 12 \\
\hline & $4 / 11 / 91$ & .06 & 33 & .2 & 32 & SR \\
\hline
\end{tabular}


Table 3.-Concentrations of dissolved anions and total sodium in water, Naval Reactors Facility and vicinity-Continued

\begin{tabular}{|c|c|c|c|c|c|c|}
\hline $\begin{array}{c}\text { Well } \\
\text { identifier }\end{array}$ & $\begin{array}{c}\text { Date } \\
\text { sampled } \\
(\mathrm{m} / \mathrm{d} / \mathrm{y})\end{array}$ & Bromide & Chloride & Fluoride & Sulfate & Sodium \\
\hline USGS 15 & $8 / 6 / 90$ & .07 & 31 & .4 & 31 & 18 \\
\hline \multirow[t]{5}{*}{ QAS-6 } & $8 / 6 / 90$ & .07 & 31 & .4 & 30 & 19 \\
\hline & $10 / 9 / 90$ & .04 & 19 & .1 & 26 & 15 \\
\hline & $12 / 13 / 90$ & .02 & 9.9 & .6 & 22 & 7.6 \\
\hline & $2 / 11 / 91$ & .02 & 7.5 & .1 & 19 & 7.3 \\
\hline & $4 / 12 / 91$ & .02 & 4.8 & .1 & 15 & 7.8 \\
\hline \multirow[t]{5}{*}{ USGS 17} & $3 / 20 / 90$ & .02 & 7.9 & .3 & 19 & 6.0 \\
\hline & $6 / 7 / 90$ & $<.(0) 1$ & 7.4 & .1 & 18 & 7.0 \\
\hline & $8 / 2 / 90$ & .03 & 6.4 & .2 & 18 & 5.7 \\
\hline & $10 / 10 / 90$ & .02 & 5.2 & .3 & 20 & 6.5 \\
\hline & $12 / 10 / 90$ & $<.01$ & 6.6 & .2 & 19 & 6.3 \\
\hline \multirow[t]{2}{*}{ USGS 97} & $3 / 19 / 90$ & .06 & 30 & .2 & 32 & 13 \\
\hline & $6 / 7 / 90$ & .06 & 31 & $<.1$ & 34 & 15 \\
\hline \multirow[t]{4}{*}{ QAS-3 } & $6 / 7 / 90$ & .06 & 34 & .4 & 34 & 14 \\
\hline & $8 / 1 / 90$ & .08 & 33 & .1 & 33 & 12 \\
\hline & $10 / 4 / 90$ & .07 & 33 & $<.1$ & 36 & 15 \\
\hline & $12 / 7 / 90$ & .06 & 32 & .1 & 36 & 13 \\
\hline QAS-10 & $12 / 7 / 90$ & .06 & 33 & .1 & 37 & 14 \\
\hline \multirow[t]{3}{*}{ USGS 98} & $3 / 19 / 90$ & .04 & 13 & .2 & 20 & 9.6 \\
\hline & $6 / 5 / 90$ & .04 & 28 & .3 & 37 & 8.8 \\
\hline & $7 / 30 / 90$ & .04 & 18 & .4 & 22 & 8.1 \\
\hline \multirow[t]{3}{*}{ QAS-5 } & $7 / 30 / 90$ &.$(1) 4$ & 18 & .7 & 23 & 8.0 \\
\hline & $10 / 3 / 90$ & .04 & 14 & $<.1$ & 19 & 9.1 \\
\hline & $12 / 7 / 90$ & .03 & 14 & .2 & 25 & 9.4 \\
\hline \multirow[t]{4}{*}{ USGS 99} & $3 / 20 / 90$ & .05 & 16 & .2 & 26 & 11 \\
\hline & $6 / 5 / 90$ & .05 & 40 & .3 & 47 & 13 \\
\hline & $8 / 1 / 90$ & .05 & 22 & .2 & 25 & 10 \\
\hline & $10 / 3 / 90$ & .05 & 19 & $<.1$ & 23 & 12 \\
\hline \multirow[t]{2}{*}{ QAS-7 } & $10 / 3 / 90$ & .05 & 19 & $<.1$ & 23 & 11 \\
\hline & $12 / 10 / 90$ & .014 & 20 & .1 & 27 & 13 \\
\hline
\end{tabular}


Table 3.-Concentrations of dissolved anions and total sodium in water, Naval Reactors Facility and vicinity-Continued

\begin{tabular}{llccccc}
\hline $\begin{array}{c}\text { Well } \\
\text { identifier }\end{array}$ & $\begin{array}{c}\text { Date } \\
\text { sampled } \\
(\mathrm{m} / \mathrm{d} / \mathrm{y})\end{array}$ & Bromide & Chloride & Fluoride & Sulfate & Sodium \\
\hline \multirow{2}{*}{ USGS 102 } & $8 / 1 / 90$ & .07 & 28 & .2 & 28 & 11 \\
& $10 / 4 / 90$ & .07 & 30 & $<.1$ & 34 & 12 \\
& $12 / 10 / 90$ & .05 & 28 & .2 & 160 & 13 \\
QAS-11 & $12 / 10 / 90$ & .06 & 30 & .1 & 33 & 14 \\
& $2 / 7 / 91$ & .07 & 30 & .2 & 31 & 12 \\
& $4 / 11 / 91$ & .07 & 31 & .2 & 32 & 11 \\
Water Supply & & & & & & \\
INEL-1 & $3 / 19 / 90$ & .32 & 110 & .2 & 52 & 18 \\
& $6 / 5 / 90$ & .33 & 140 & .3 & 84 & 20 \\
& $7 / 30 / 90$ & .33 & 110 & .5 & 60 & 17 \\
& $10 / 3 / 90$ & .34 & 110 & $<.1$ & 54 & 19 \\
& $12 / 7 / 90$ & .29 & 110 & .1 & 53 & 18 \\
QAS-9 & $12 / 7 / 90$ & .29 & 110 & .1 & 53 & 18 \\
\hline
\end{tabular}


Table 4.-Statistical parameters for dissolved anions and total sodium, by well

IUnits are milligrams per liter. Values are derived from table 3. See figure 2 for location of wells. Quality assurance replicates are included in the statistical parameters. Mean and median sample size: includes all samples with concentrations greater than laboratory reporting level]

\begin{tabular}{|c|c|c|c|c|c|c|}
\hline \multirow[b]{2}{*}{ Constituent } & \multicolumn{5}{|c|}{ Statistical parameter } & \multirow[b]{2}{*}{$\begin{array}{l}\text { Mean and } \\
\text { median } \\
\text { sample size }\end{array}$} \\
\hline & Minimum & Maximum & Median & Mean & $\begin{array}{l}\text { Sample } \\
\text { size }\end{array}$ & \\
\hline \multicolumn{7}{|c|}{ NRF-1 } \\
\hline Bromide & 0.06 & 0.07 & 0.07 & 0.07 & 5 & 5 \\
\hline Chloride & 33 & 34 & 33 & 33 & 5 & 5 \\
\hline Fluoride & $<.1$ & .5 & .3 & .3 & 5 & 3 \\
\hline Sulfate & 35 & 43 & 36 & 37 & 5 & 5 \\
\hline Sodium & 13 & 13 & 13 & 13 & 5 & 5 \\
\hline \multicolumn{7}{|c|}{ NRF-2 } \\
\hline Bromide & .06 & .08 & .07 & .07 & 6 & 6 \\
\hline Chloride & 39 & 50 & 45 & 45 & 6 & 6 \\
\hline Fluoride & $<.1$ & .5 & .3 & .4 & 6 & 3 \\
\hline Sulfate & 39 & 52 & 46.5 & 46 & 6 & 6 \\
\hline Sodium & 17 & 20 & 17.5 & 18 & 6 & 6 \\
\hline \multicolumn{7}{|c|}{ NRF-3 } \\
\hline Bromide & .06 & .07 & .07 & .07 & 5 & 5 \\
\hline Chloride & 30 & 34 & 31 & 32 & 5 & 5 \\
\hline Fluoride & $<.1$ & .6 & .25 & .3 & 5 & 4 \\
\hline Sulfate & 34 & 38 & 35 & 36 & 5 & 5 \\
\hline Sodium & 12 & 14 & 13 & 13 & 5 & 5 \\
\hline \multicolumn{7}{|c|}{ NRF-4 } \\
\hline Bromide & .05 & .08 & .065 & .06 & 6 & 6 \\
\hline Chloride & 37 & 42 & 41 & 40) & 6 & 6 \\
\hline Fluoride & $<.1$ & .6 & .2 & .3 & 6 & 5 \\
\hline Sulfate & 38 & 47 & 42 & 42 & 6 & 6 \\
\hline Sodium & 14 & 18 & 16 & 16 & 6 & 6 \\
\hline \multicolumn{7}{|c|}{ USGS 12} \\
\hline Bromide & .06 & .08 & .07 & .07 & 5 & 5 \\
\hline Chloride & 32 & 35 & 33 & 33 & 5 & 5 \\
\hline Fluoride & .1 & .4 & .2 & .2 & 5 & 5 \\
\hline Sulfate & 32 & 35 & 33 & 3.3 & 5 & 5 \\
\hline Sodium & 10 & 12 & 12 & 12 & 4 & 4 \\
\hline
\end{tabular}


Table 4.- Statistical parameters for dissolved anions and total sodium, by well-Continued

\begin{tabular}{|c|c|c|c|c|c|c|}
\hline \multirow[b]{2}{*}{ Constituent } & \multicolumn{6}{|c|}{ Statistical parameter } \\
\hline & Minimum & Maximum & Median & Mean & $\begin{array}{c}\text { Sample } \\
\text { size }\end{array}$ & $\begin{array}{c}\text { Mean and } \\
\text { median } \\
\text { sample size }\end{array}$ \\
\hline
\end{tabular}

\begin{tabular}{|c|c|c|c|c|c|c|}
\hline \multicolumn{7}{|c|}{ USGS 15} \\
\hline Bromide & .02 & .07 & .03 & .04 & 6 & 6 \\
\hline Chloride & 4.8 & 31 & 14.45 & 17 & 6 & 6 \\
\hline Fluoride & .1 & .6 & .25 & .3 & 6 & 6 \\
\hline Sulfate & 15 & 31 & 24 & 24 & 6 & 6 \\
\hline Sodium & 7.3 & 19 & 11.4 & 12 & 6 & 6 \\
\hline \multicolumn{7}{|c|}{ USGS 17} \\
\hline Bromide & $<.01$ & .03 & .02 & .02 & 5 & 3 \\
\hline Chloride & 5.2 & 7.9 & 6.6 & 6.7 & 5 & 5 \\
\hline Fluoride & .1 & .3 & .2 & .2 & 5 & 5 \\
\hline Sulfate & 18 & 20 & 19 & 19 & 5 & 5 \\
\hline Sodium & 5.7 & 7.0 & 6.3 & 6.3 & 5 & 5 \\
\hline \multicolumn{7}{|c|}{ USGS 97} \\
\hline Bromide & .06 & .08 & .06 & .06 & 7 & 7 \\
\hline Chloride & 30 & 34 & 33 & 32 & 7 & 7 \\
\hline Fluoride & $<.1$ & .4 & .1 & .2 & 7 & 5 \\
\hline Sulfate & 32 & 37 & 34 & 35 & 7 & 7 \\
\hline Sodium & 12 & 15 & 14 & 14 & 7 & 7 \\
\hline \multicolumn{7}{|c|}{ USGS 98} \\
\hline Bromide & .03 & .04 & .04 & .04 & 6 & 6 \\
\hline Chloride & 13 & 28 & 16 & 18 & 6 & 6 \\
\hline Fluoride & $<.1$ & .7 & .3 & .4 & 6 & 5 \\
\hline Sulfate & 19 & 37 & 22.5 & 24 & 6 & 6 \\
\hline Sodium & 8.0 & 9.6 & 8.95 & 8.8 & 6 & 6 \\
\hline \multicolumn{7}{|c|}{ USGS 99} \\
\hline Bromide & .04 & .05 & .05 & .05 & 6 & 6 \\
\hline Chloride & 16 & 40 & 19.5 & 23 & 6 & 6 \\
\hline Fluoride & $<.1$ & .3 & .2 & .2 & 6 & 4 \\
\hline Sulfate & 23 & 47 & 25.5 & 28 & 6 & 6 \\
\hline Sodium & 10 & 13 & 11.5 & 12 & 6 & 6 \\
\hline
\end{tabular}


Table 4.-Statistical parameters for dissolved anions and total sodium, by well-Continued

\begin{tabular}{|c|c|c|c|c|c|c|}
\hline \multirow[b]{2}{*}{ Constituent } & \multicolumn{6}{|c|}{ Statistical parameter } \\
\hline & Minimum & Maximum & Median & Mean & $\begin{array}{c}\text { Sample } \\
\text { size }\end{array}$ & $\begin{array}{l}\text { Mean and } \\
\text { median } \\
\text { sample size }\end{array}$ \\
\hline \multicolumn{7}{|c|}{ USGS 102} \\
\hline Bromide & .05 & .07 & .07 & .06 & 6 & 6 \\
\hline Chloride & 28 & 31 & 30 & 30) & 6 & 6 \\
\hline Fluoride & $<.1$ & .2 & .2 & .2 & 6 & 5 \\
\hline Sulfate & 28 & 160 & 32.5 & 53 & 6 & 6 \\
\hline Sodium & 11 & 14 & 12 & 12 & 6 & 6 \\
\hline \multicolumn{7}{|c|}{ Water Supply INEL-1 } \\
\hline Bromide & .29 & .34 & .325 & .32 & 6 & 6 \\
\hline Chloride & 110 & 140 & 110 & 12 & 6 & 6 \\
\hline Fluoride & $<.1$ & .5 & .2 & .2 & 6 & 5 \\
\hline Sulfate & 52 & 84 & 53.5 & 59 & 6 & 6 \\
\hline Sodium & 17 & 20 & 18 & 18 & 6 & 6 \\
\hline \multicolumn{7}{|c|}{ All wells } \\
\hline Bromide & $<.01$ & .34 & .06 & .08 & 69 & 67 \\
\hline Chloride & 4.8 & 140 & 32 & 36 & 69 & 69 \\
\hline Fluoride & $<.1$ & .7 & .2 & .3 & 69 & 55 \\
\hline Sulfate & 15 & 160 & 34 & 37 & 69 & 69 \\
\hline Sodium & 5.7 & 20 & 13 & 13 & 68 & 68 \\
\hline
\end{tabular}




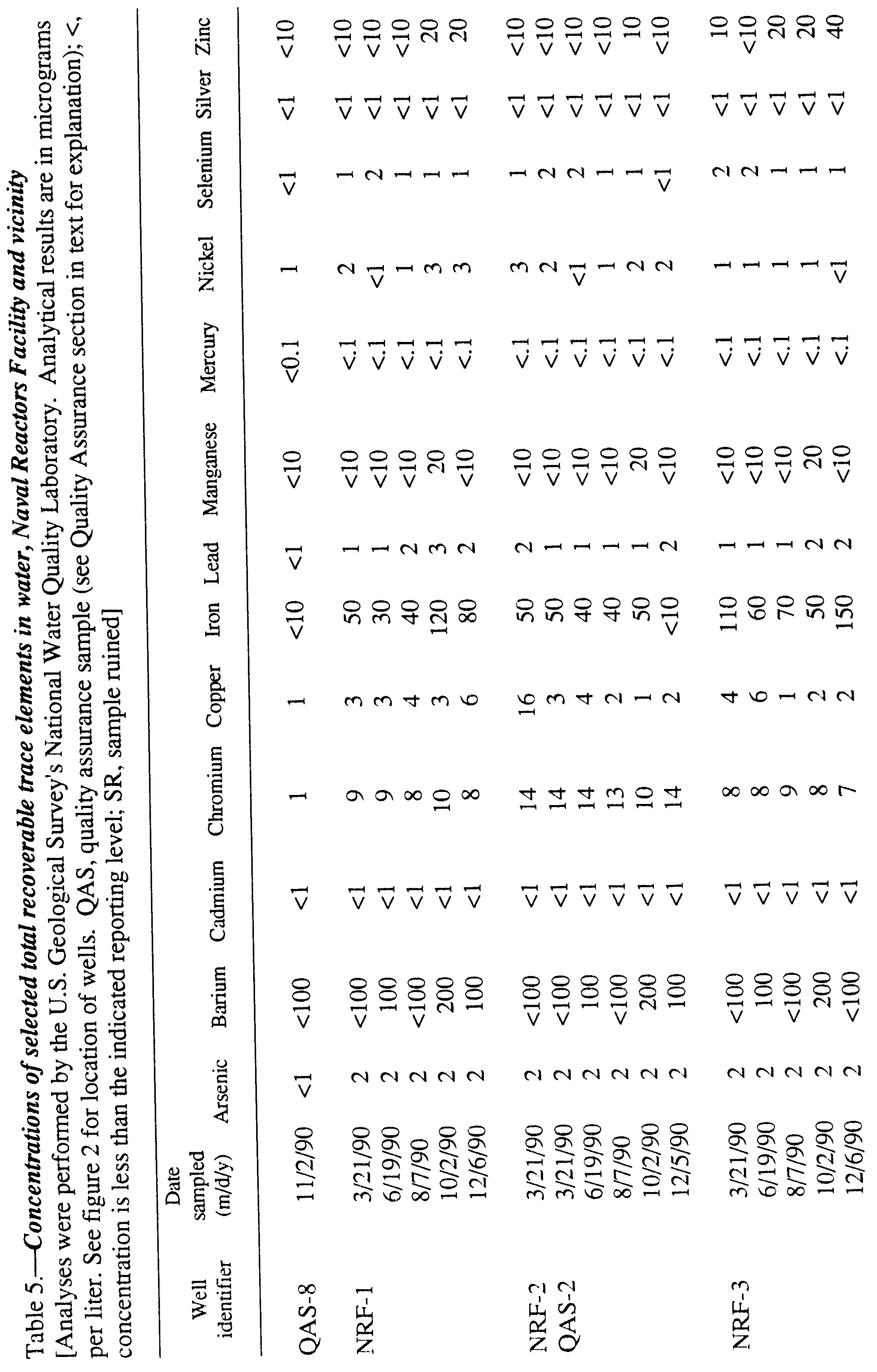




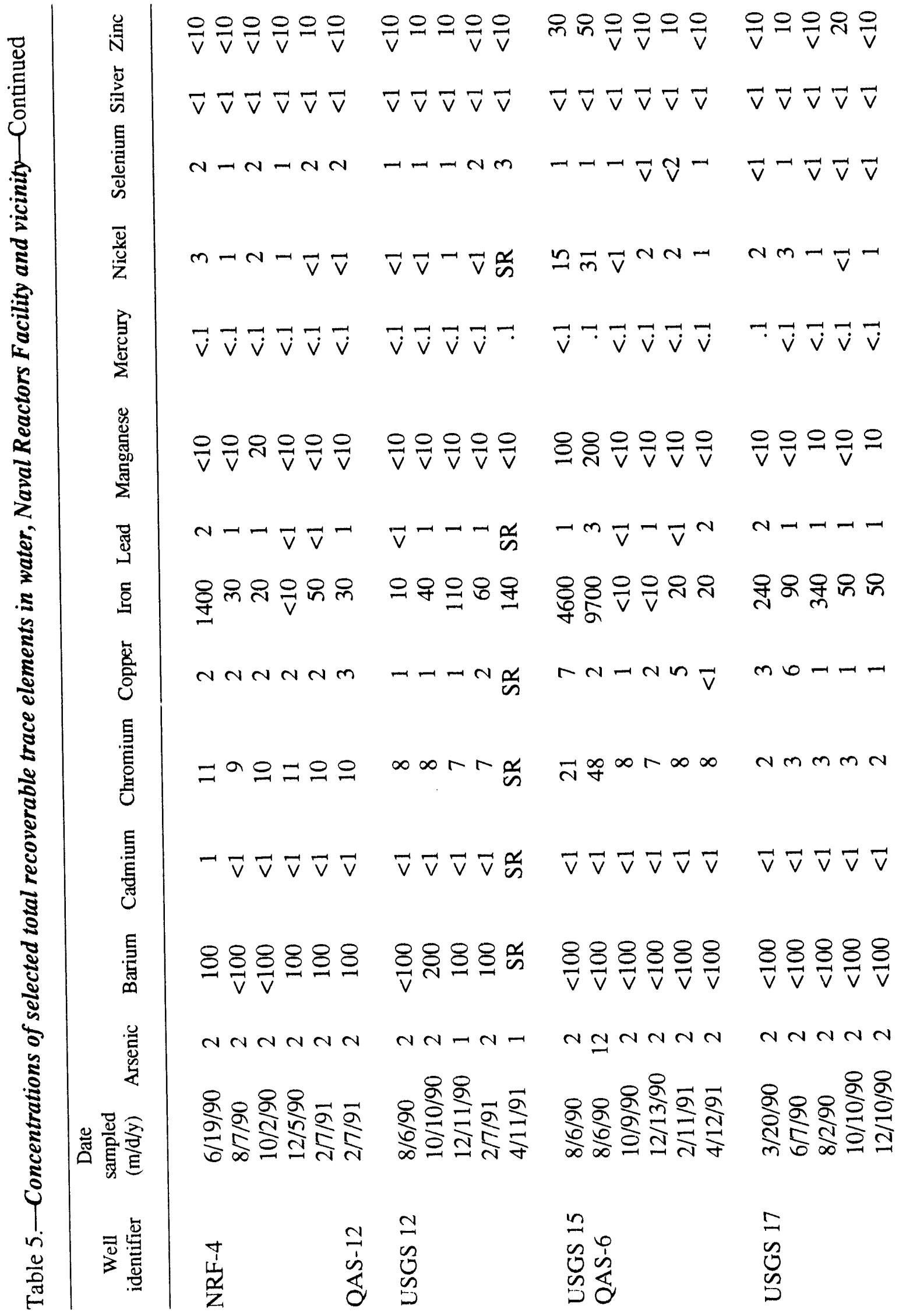




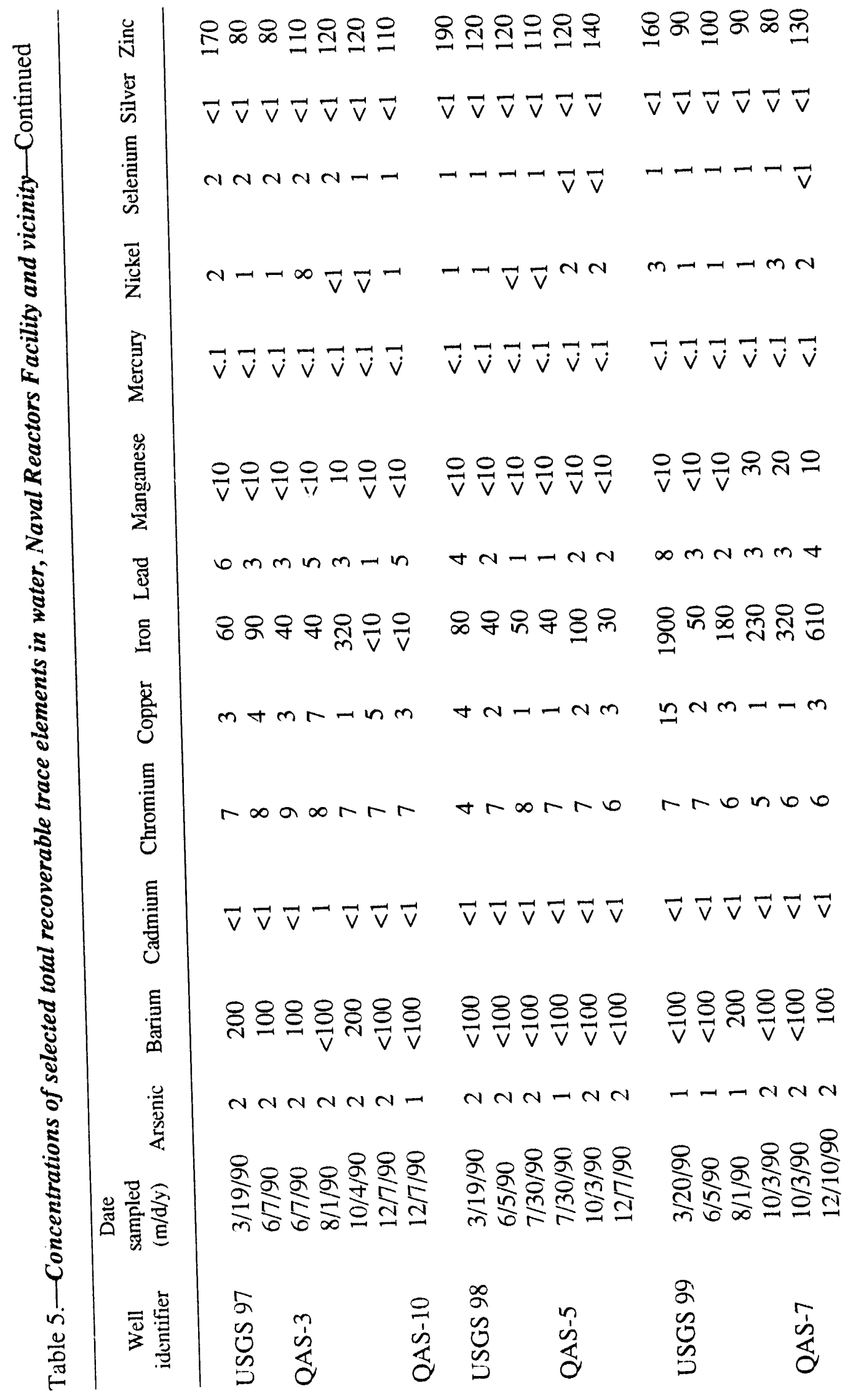




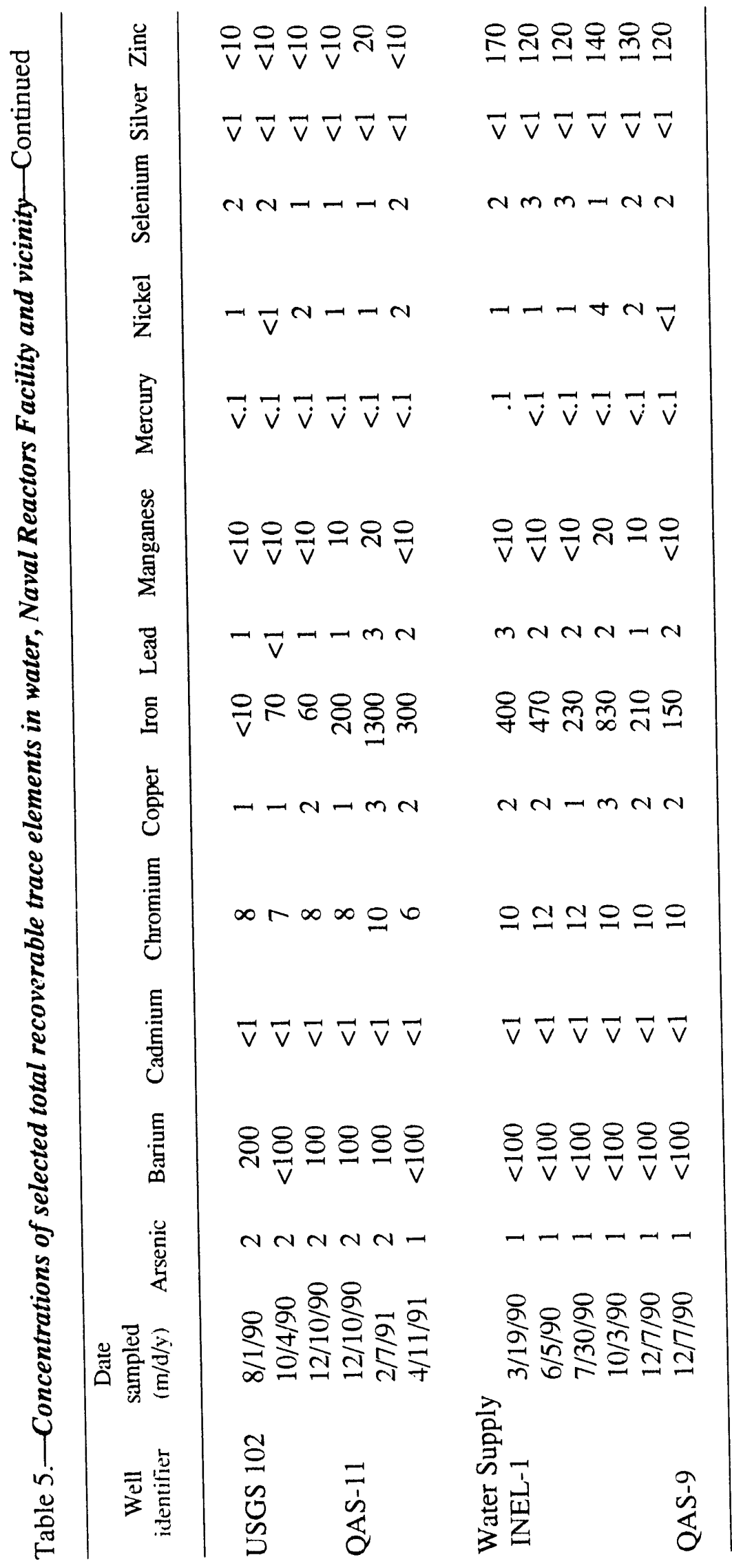


Table 6.-Statistical parameters for selected total recoverable trace elements, by well IUnits are milligrams per liter. Values are derived from table 5. See figure 2 for location of wells. Quality assurance replicates are included in the statistical parameters. Mean and median sample size: includes all samples with concentrations greater than laboratory reporting level]

\begin{tabular}{|c|c|c|c|c|c|c|}
\hline \multirow[b]{2}{*}{ Constituent } & \multicolumn{6}{|c|}{ Statistical parameter } \\
\hline & Minimum & Maximum & Median & Mean & $\begin{array}{c}\text { Sample } \\
\text { size }\end{array}$ & $\begin{array}{l}\text { Mean and } \\
\text { median } \\
\text { sample size }\end{array}$ \\
\hline
\end{tabular}

NRF-1

$\begin{array}{lrr}\text { Arsenic } & 2 & 2 \\ \text { Barium } & <100 & 200 \\ \text { Chromium } & 8 & 10 \\ \text { Copper } & 3 & 6 \\ \text { Iron } & 30 & 120 \\ \text { Lead } & 1 & 3 \\ \text { Nickel } & <1 & 3 \\ \text { Selenium } & 1 & 2\end{array}$

Selenium

2

10

6

120

3

2

Arsenic

Barium

Chromium

Copper

Iron

Lead

Nickel

Selenium

Arsenic

Chromium

Copper

Iron

Lead

Nickel

Selenium

Zinc

2
$<100$
10
1
$<10$
1
$<1$
$<1$

2

2

200

14

16

50

2

3

2

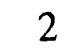

9

6

150)

2

1

2

40)

$$
\begin{array}{r}
1 \\
<1 \\
1 \\
<10
\end{array}
$$

Arsenic

Barium

Chromium

$\begin{array}{rr}2 & 2 \\ 100 & 100 \\ 9 & 9 \\ 3 & 4 \\ 5() & 60 \\ 2 & 2 \\ 2.5 & 2 \\ 1 & 1\end{array}$

NRF-2

$\begin{array}{crrr}2 & 2 & 6 & 6 \\ 100 & 100 & 5 & 3 \\ 14 & 13 & 6 & 6 \\ 2.5 & 5 & 6 & 6 \\ 50 & 50 & 6 & 5 \\ 1 & 1 & 6 & 6 \\ 2 & 2 & 6 & 5 \\ 1 & 1 & 6 & 5\end{array}$

NRF-3

$\begin{array}{rrrr}2 & 2 & 5 & 5 \\ 8 & 8 & 5 & 5 \\ 2 & 3 & 5 & 5 \\ 70 & 90 & 5 & 5 \\ 1 & 1 & 5 & 5 \\ 1 & 1 & 5 & 4 \\ 1 & 1 & 5 & 5 \\ 20 & 20 & 5 & 4\end{array}$

NRF-4

$\begin{array}{rrrr}2 & 2 & 6 & 6 \\ 10() & 10() & 6 & 4 \\ 10 & 10 & 6 & 6\end{array}$


Table 6.- Statistical parameters for selected total recoverable trace elements, by well-Continued

\begin{tabular}{|c|c|c|c|c|c|c|}
\hline \multirow[b]{2}{*}{ Constituent } & \multicolumn{6}{|c|}{ Statistical parameter } \\
\hline & Minimum & Maximum & Median & Mean & $\begin{array}{c}\text { Sample } \\
\text { size }\end{array}$ & $\begin{array}{l}\text { Mean and } \\
\text { median } \\
\text { sample size }\end{array}$ \\
\hline
\end{tabular}

\begin{tabular}{lrrrrrr}
\hline & \multicolumn{7}{c}{ NRF-4 (continued) } \\
Copper & 2 & 3 & 2 & 2 & 6 & 6 \\
Iron & $<10$ & 1400 & 30 & 310 & 6 & 5 \\
Lead & $<1$ & 2 & 1 & 1 & 6 & 4 \\
Nickel & $<1$ & 3 & 1.5 & 2 & 6 & 4 \\
Selenium & 1 & 2 & 2 & 2 & 6 & 6
\end{tabular}

$\begin{array}{lrrrrrr}\text { Arsenic } & 1 & 2 & 2 & 2 & 5 & 5 \\ \text { Barium } & <100 & 200 & 100 & 100 & 4 & 3 \\ \text { Chromium } & 7 & 8 & 7.5 & 8 & 4 & 4 \\ \text { Copper } & 1 & 2 & 1 & 1 & 4 & 4 \\ \text { Iron } & 10 & 140 & 60 & 70 & 5 & 5 \\ \text { Lead } & <1 & 1 & 1 & 1 & 4 & 3 \\ \text { Selenium } & 1 & 3 & 1 & 2 & 5 & 5\end{array}$

USGS 15

Arsenic

Chromium

12

Copper

Iron

Lead

Nickel

Selenium

Zinc

$\quad 2$
$\quad<1$
$<10$
$<1$
$<1$
$<1$
$<10$

48

7

97() 0

3

31

1

50

$\begin{array}{cr}2 & 4 \\ 8 & 17 \\ 2 & 3 \\ 2310 & 3600 \\ 1.5 & 2 \\ 2 & 10 \\ 1 & 1 \\ 30 & 30\end{array}$

USGS 17

Arsenic

Chromium

Copper

Iron

Lead

Nickel

2
2
1
50
1
$<1$

2

3

6

340

2

3

$\begin{array}{rr}2 & 2 \\ 3 & 3 \\ 1 & 2 \\ 90 & 150 \\ 1 & 1 \\ 1.5 & 2\end{array}$

$6 \quad 6$

$6 \quad 6$

65

64

64

65

64

63


Table 6.-Statistical parameters for selected total recoverable trace elements, by well-Continued

\begin{tabular}{|c|c|c|c|c|c|c|}
\hline \multirow[b]{2}{*}{ Constituent } & \multicolumn{6}{|c|}{ Statistical parameter } \\
\hline & Minimum & Maximum & Median & Mean & $\begin{array}{l}\text { Sample } \\
\text { size }\end{array}$ & $\begin{array}{c}\text { Mean anc } \\
\text { median } \\
\text { sample siz }\end{array}$ \\
\hline & & & USGS 97 & & & \\
\hline Arsenic & 1 & 2 & 2 & 2 & 7 & 7 \\
\hline Barium & $<100$ & 200 & 150 & 200 & 7 & 4 \\
\hline Chromium & 7 & 9 & 7 & 8 & 7 & 7 \\
\hline Copper & 1 & 7 & 3 & 4 & 7 & 7 \\
\hline Iron & $<10$ & 320 & 60 & 110 & 7 & 5 \\
\hline Lead & 1 & 6 & 3 & 4 & 7 & 7 \\
\hline Nickel & $<1$ & 8 & 1 & 3 & 7 & 5 \\
\hline Selenium & 1 & 2 & 2 & 2 & 7 & 7 \\
\hline \multirow[t]{2}{*}{ Zinc } & 80 & 170 & 110 & 110 & 7 & 7 \\
\hline & & & USGS 98 & & & \\
\hline Arsenic & 1 & 2 & 2 & 2 & 6 & 6 \\
\hline Chromium & 4 & 8 & 7 & 6 & 6 & 6 \\
\hline Copper & 1 & 4 & 2 & 2 & 6 & 6 \\
\hline Iron & 30 & 100 & 45 & 60 & 6 & 6 \\
\hline Lead & 1 & 4 & 2 & 2 & 6 & 6 \\
\hline Nickel & $<1$ & 2 & 1.5 & 2 & 6 & 4 \\
\hline Selenium & $<1$ & 1 & 1 & 1 & 6 & 4 \\
\hline Zinc & 110 & 190 & 120 & 130 & 6 & 6 \\
\hline
\end{tabular}

$\begin{array}{lrrrrrr}\text { Arsenic } & 1 & 2 & 1.5 & 2 & 6 & 6 \\ \text { Chromium } & 5 & 7 & 6 & 6 & 6 & 6 \\ \text { Copper } & 1 & 15 & 2.5 & 4 & 6 & 6 \\ \text { Iron } & 50 & 1900 & 275 & 550 & 6 & 5 \\ \text { Lead } & 2 & 8 & 3 & 4 & 6 & 6 \\ \text { Manganese } & <10 & 30 & 20 & 20 & 6 & 3 \\ \text { Nickel } & 1 & 3 & 1.5 & 2 & 6 & 6 \\ \text { Selenium } & <1 & 1 & 1 & 1 & 6 & 5 \\ \text { Zinc } & 80 & 160 & 95 & 110 & 6 & 6 \\ & & & & & & \\ \text { Arsenic } & 1 & 2 & \text { USGS 102 } & & & \\ \text { Barium } & <100 & 200 & 100 & 100 & 6 & 6 \\ \text { Chromium } & 6 & 10 & 8 & 8 & 6 & 6 \\ \text { Copper } & 1 & 3 & 1.5 & 2 & 6 & 6\end{array}$


Table 6.- Statistical parameters for selected total recoverable trace elements, by well-Continued

\begin{tabular}{|c|c|c|c|c|c|c|}
\hline \multirow[b]{2}{*}{ Constituent } & \multicolumn{6}{|c|}{ Statistical parameter } \\
\hline & Minimum & Maximum & Median & Mean & $\begin{array}{c}\text { Sample } \\
\text { size }\end{array}$ & $\begin{array}{l}\text { Mean and } \\
\text { median } \\
\text { sample size }\end{array}$ \\
\hline \multicolumn{7}{|c|}{ USGS 102 (continued) } \\
\hline Iron & $<10$ & 1300 & 200 & 390 & 6 & 5 \\
\hline Lead & $<1$ & 3 & 1 & 2 & 6 & 5 \\
\hline Nickel & $<1$ & 2 & 1 & 1 & 6 & 5 \\
\hline Selenium & 1 & 2 & 1.5 & 2 & 6 & 6 \\
\hline \multicolumn{7}{|c|}{ Water Supply INEL-1 } \\
\hline Arsenic & 1 & 1 & 1 & 1 & 6 & 6 \\
\hline Chromium & 10 & 12 & 10 & 11 & 6 & 6 \\
\hline Copper & 1 & 3 & 2 & 2 & 6 & 6 \\
\hline Iron & 150 & 830 & 315 & 380 & 6 & 6 \\
\hline Lead & 1 & 3 & 2 & 2 & 6 & 6 \\
\hline Nickel & $<1$ & 4 & 1 & 2 & 6 & 5 \\
\hline Selenium & 1 & 3 & 2 & 2 & 6 & 6 \\
\hline Zinc & 120 & 170 & 125 & 130 & 6 & 6 \\
\hline \multicolumn{7}{|c|}{ All wells } \\
\hline Arsenic & 1 & 12 & 2 & 2 & 69 & 69 \\
\hline Barium & $<100$ & 200 & 100 & 100 & 68 & 25 \\
\hline Chromium & 2 & 48 & 8 & 9 & 68 & 68 \\
\hline Copper & $<1$ & 16 & 2 & 3 & 68 & 67 \\
\hline Iron & $<10$ & 9700 & 70 & 430 & 69 & 62 \\
\hline Lead & $<1$ & 8 & 2 & 2 & 68 & 62 \\
\hline Manganese & $<10$ & 200 & 20 & 30 & 69 & 16 \\
\hline Nickel & $<1$ & 31 & 2 & 3 & 68 & 52 \\
\hline Selenium & $<1$ & 3 & 1 & 1 & 69 & 59 \\
\hline Zinc & $<10$ & 190 & 90 & 80 & 69 & 41 \\
\hline
\end{tabular}


Table 7.-Concentrations of selected dissolvea trace elements in water from Water Supply INEL-1, in the vicinity of the Naval Reactors Facility

[Analyses were performed by the U.S. Geological Survey's National Water Quality Laboratory. Analytical results are in micrograms per liter. Water sample was collected on July 30, 1990, as part of a special request. <, concentration is less thai indicated reporting level]

Trace element

Concentration

Arsenic

1

Barium

74

Cadmium

$<1$

Chromium

10

Iron

29

Lead

$<1$

Mercury

Selenium

3

Silver

$<1$ 
Table 8.-Concentrations of dissolved nutrients in water, Naval Reactors Facility and vicinity [Analyses were performed by the U.S. Geological Survey's National Water Quality Laboratory. Analytical results are in milligrams per liter. See figure 2 for location of wells. QAS, quality assurance sample (see Quality Assurance section in text for explanation); <, concentration is less than the indicated reporting level; NR, analysis not requested]

\begin{tabular}{|c|c|c|c|c|c|c|}
\hline $\begin{array}{l}\text { Well } \\
\text { identifier }\end{array}$ & $\begin{array}{c}\text { Date } \\
\text { sampled } \\
(\mathrm{m} / \mathrm{d} / \mathrm{y})\end{array}$ & $\begin{array}{l}\text { Ammonia } \\
\quad \text { (as } \\
\text { nitrogen) }\end{array}$ & $\begin{array}{l}\text { Ammonia } \\
\text { plus organic } \\
\text { nitrogen (as } \\
\text { nitrogen) }\end{array}$ & $\begin{array}{l}\text { Nitrite } \\
\text { (as } \\
\text { nitrogen) }\end{array}$ & \begin{tabular}{l}
\multicolumn{1}{c}{ Nitrite } \\
plus \\
nitrate (as \\
nitrogen)
\end{tabular} & $\begin{array}{c}\text { Ortho } \\
\text { phosphate } \\
\text { (as phos- } \\
\text { phorus) }\end{array}$ \\
\hline QAS-8 & $11 / 2 / 90$ & 0.01 & $<0.2$ & $<0.01$ & $<0.1$ & $<0.1$ \\
\hline \multirow[t]{5}{*}{ NRF-1 } & $3 / 21 / 90$ & NR & NR & $<.01$ & 1.6 & NR \\
\hline & $6 / 19 / 90$ & NR & NR & $<.01$ & 1.6 & NR \\
\hline & $8 / 7 / 90$ & NR & NR & $<.01$ & 1.6 & NR \\
\hline & $10 / 2 / 90$ & $<.01$ & .5 & $<.01$ & 1.6 & $<.01$ \\
\hline & $12 / 6 / 90$ & .03 & $<.2$ & $<.01$ & 1.5 & .02 \\
\hline NRF-2 & $3 / 21 / 90$ & NR & NR & $<.01$ & 1.9 & NR \\
\hline \multirow[t]{5}{*}{ QAS-2 } & $3 / 21 / 90$ & NR & NR & $<.01$ & 1.8 & NR \\
\hline & $6 / 19 / 90$ & NR & NR & $<.01$ & 1.7 & NR \\
\hline & $8 / 7 / 90$ & NR & NR & $<.01$ & 1.8 & NR \\
\hline & $10 / 2 / 90$ & $<.01$ & .4 & $<.01$ & 1.7 & $<.01$ \\
\hline & $12 / 5 / 90$ & .03 & $<.2$ & $<.01$ & 1.7 & .02 \\
\hline \multirow[t]{5}{*}{ NRF-3 } & $3 / 21 / 90$ & NR & NR & $<.01$ & 1.6 & NR \\
\hline & $6 / 19 / 90$ & NR & NR & $<.01$ & 1.6 & NR \\
\hline & $8 / 7 / 90$ & NR & NR & $<.01$ & 1.7 & NR \\
\hline & $10 / 2 / 90$ & $<.01$ & .5 & $<.01$ & 1.6 & $<.01$ \\
\hline & $12 / 6 / 90$ & .02 & $<.2$ & $<.01$ & 1.6 & .02 \\
\hline \multirow[t]{5}{*}{ NRF-4 } & $6 / 19 / 90$ & NR & NR & $<.01$ & 1.9 & NR \\
\hline & $8 / 7 / 90$ & NR & NR & $<.01$ & 1.8 & NR \\
\hline & $10 / 2 / 90$ & $<.01$ & .5 & $<.01$ & 1.9 & .01 \\
\hline & $12 / 5 / 90$ & .03 & $<.2$ & $<.01$ & 1.8 & .02 \\
\hline & $2 / 7 / 91$ & .01 & .5 & $<.01$ & 1.8 & .02 \\
\hline QAS-12 & $2 / 7 / 91$ & .02 & 1.1 & $<.01$ & 1.8 & .04 \\
\hline \multirow[t]{5}{*}{ USGS 12} & $8 / 6 / 90$ & NR & NR & $<.01$ & 1.6 & NR \\
\hline & $10 / 10 / 90$ & $<.01$ & .3 & $<.01$ & 1.7 & .01 \\
\hline & $12 / 11 / 90$ & .02 & .2 & $<.01$ & 1.8 & .02 \\
\hline & $2 / 7 / 91$ & $<.01$ & .3 & .02 & 1.7 & .02 \\
\hline & $4 / 11 / 91$ & NR & $<.2$ & $<.01$ & 1.7 & $<.01$ \\
\hline
\end{tabular}


Table 8.-Concentrations of dissolved nutrients in water, Naval Reactors Facility and vicinity-Continued

\begin{tabular}{|c|c|c|c|c|c|c|}
\hline $\begin{array}{l}\text { Well } \\
\text { identifier }\end{array}$ & $\begin{array}{c}\text { Date } \\
\text { sampled } \\
(\mathrm{m} / \mathrm{d} / \mathrm{y})\end{array}$ & $\begin{array}{l}\text { Ammonia } \\
\quad \text { (as } \\
\text { nitrogen) }\end{array}$ & $\begin{array}{l}\text { Ammonia } \\
\text { plus organic } \\
\text { nitrogen (as } \\
\text { nitrogen) }\end{array}$ & $\begin{array}{l}\text { Nitrite } \\
\text { (as } \\
\text { nitrogen) }\end{array}$ & $\begin{array}{l}\text { Nitrite } \\
\text { plus } \\
\text { nitrate (as } \\
\text { nitrogen) }\end{array}$ & $\begin{array}{c}\text { Ortho } \\
\text { phosphate } \\
\text { (as phos- } \\
\text { phorus) }\end{array}$ \\
\hline USGS 15 & $8 / 6 / 90$ & NR & NR & $<.01$ & 1.8 & NR \\
\hline \multirow[t]{5}{*}{ QAS-6 } & $8 / 6 / 90$ & NR & NR & $<.01$ & 16 & NR \\
\hline & $10 / 9 / 90$ & $<.01$ & $<.2$ & $<.01$ & 1.2 & $<.01$ \\
\hline & $12 / 13 / 90$ & .01 & $<.2$ & $<.01$ & .40 & .02 \\
\hline & $2 / 11 / 91$ & $<.01$ & .3 & $<.01$ & .31 & $<.01$ \\
\hline & $4 / 12 / 91$ & NR & $<.2$ & $<.01$ & .31 & $<.01$ \\
\hline \multirow[t]{5}{*}{ USGS 17} & $3 / 20 / 90$ & NR & NR & $<.01$ & .30 & NR \\
\hline & $6 / 7 / 90$ & NR & NR & $<.01$ & .30 & NR \\
\hline & $8 / 2 / 90$ & NR & NR & $<.01$ & 1.6 & NR \\
\hline & $10 / 10 / 90$ & $<.01$ & .2 & $<.01$ & .30 & $<.01$ \\
\hline & $12 / 10 / 90$ & $<.01$ & .4 & $<.01$ & .30 & .02 \\
\hline \multirow[t]{2}{*}{ USGS 97} & $3 / 19 / 90$ & NR & NR & $<.01$ & 2.0 & NR \\
\hline & $6 / 7 / 90$ & NR & NR & $<.01$ & 1.8 & NR \\
\hline \multirow[t]{4}{*}{ QAS-3 } & $6 / 7 / 90$ & NR & NR & $<.01$ & 1.8 & NR \\
\hline & $8 / 1 / 90$ & NR & NR & $<.01$ & 1.8 & NR \\
\hline & $10 / 4 / 90$ & $<.01$ & $<.2$ & $<.01$ & 1.9 & .02 \\
\hline & $12 / 7 / 90$ & $<.01$ & $<.2$ & $<.01$ & 1.8 & .02 \\
\hline QAS-10 & $12 / 7 / 90$ & .01 & $<.2$ & $<.01$ & 1.8 & .03 \\
\hline \multirow[t]{3}{*}{ USGS 98} & $3 / 19 / 90$ & NR & NR & $<.01$ & 3.0 & NR \\
\hline & $6 / 5 / 90$ & NR & NR & $<.01$ & 1.1 & NR \\
\hline & $7 / 30 / 90$ & NR & NR & $<.01$ & 1.1 & NR \\
\hline \multirow[t]{3}{*}{ QAS-5 } & $7 / 30 / 90$ & NR & NR & $<.01$ & 1.1 & NR \\
\hline & $10 / 3 / 90$ & $<.01$ & .3 & $<.01$ & 1.0 & $<.01$ \\
\hline & $12 / 7 / 90$ & .01 & $<.2$ & $<.01$ & 1.1 & .01 \\
\hline \multirow[t]{4}{*}{ USGS 99} & $3 / 20 / 90$ & NR & NR & $<.01$ & 1.5 & NR \\
\hline & $6 / 5 / 90$ & NR & NR & $<.01$ & 1.6 & NR \\
\hline & $8 / 1 / 90$ & NR & NR & $<.01$ & 1.6 & NR \\
\hline & $10 / 3 / 90$ & $<.01$ & .5 & $<.01$ & 1.5 & .01 \\
\hline \multirow[t]{2}{*}{ QAS-7 } & $10 / 3 / 90$ & $<.01$ & .3 & $<.01$ & 1.5 & $<.01$ \\
\hline & $12 / 10 / 90$ & $<.01$ & .3 & $<.01$ & 1.5 & .02 \\
\hline
\end{tabular}


Table 8.-Concentrations of dissolved nutrients in water, Naval Reactors Facility and vicinity-Continued

\begin{tabular}{|c|c|c|c|c|c|c|}
\hline $\begin{array}{l}\text { Well } \\
\text { identifier }\end{array}$ & $\begin{array}{c}\text { Date } \\
\text { sampled } \\
(\mathrm{m} / \mathrm{d} / \mathrm{y})\end{array}$ & $\begin{array}{l}\text { Ammonia } \\
\quad \text { (as } \\
\text { nitrogen) }\end{array}$ & $\begin{array}{c}\text { Ammonia } \\
\text { plus organic } \\
\text { nitrogen (as } \\
\text { nitrogen) }\end{array}$ & $\begin{array}{l}\text { Nitrite } \\
\text { (as } \\
\text { nitrogen) }\end{array}$ & $\begin{array}{l}\text { Nitrite } \\
\text { plus } \\
\text { nitrate (as } \\
\text { nitrogen) }\end{array}$ & $\begin{array}{l}\text { Ortho } \\
\text { phosphate } \\
\text { (as phos- } \\
\text { phorus) }\end{array}$ \\
\hline \multirow[t]{3}{*}{ USGS 102} & $8 / 1 / 90$ & NR & NR & $<.01$ & .30 & NR \\
\hline & $10 / 4 / 90$ & $<.01$ & $<.2$ & $<.01$ & 1.7 & .01 \\
\hline & $12 / 10 / 90$ & $<.01$ & $<.2$ & $<.01$ & 1.7 & .02 \\
\hline \multirow[t]{3}{*}{ QAS-11 } & $12 / 10 / 90$ & $<.01$ & .2 & $<.01$ & 1.7 & .02 \\
\hline & $2 / 7 / 91$ & $<.01$ & .4 & $<.01$ & 1.6 & .02 \\
\hline & $4 / 11 / 91$ & NR & .5 & $<.01$ & 1.7 & .01 \\
\hline \multicolumn{7}{|c|}{ Water Supply } \\
\hline \multirow[t]{5}{*}{ INEL-1 } & $3 / 19 / 90$ & NR & NR & $<.(01$ & 5.6 & NR \\
\hline & $6 / 5 / 90$ & NR & NR & $<.(01$ & 5.4 & NR \\
\hline & $7 / 30 / 90$ & NR & NR & $<.01$ & 5.6 & NR \\
\hline & $10 / 3 / 90$ & $<.(01$ & 1.2 & $<.01$ & 5.5 & $<.01$ \\
\hline & $12 / 7 / 90$ & .02 & .4 & $<.01$ & 5.1 & .01 \\
\hline QAS-9 & $12 / 7 / 90$ & .02 & .3 & $<.01$ & 5.0 & $<.01$ \\
\hline
\end{tabular}


Table 9.-Concentrations of total organic carbon and total phenols in water, and turbidity, Naval Reactors Facility and vicinity

[Analyses were performed by the U.S. Geological Survey's National Water Quality Laboratory. Analytical results are in milligrams per liter for total organic carbon, micrograms per liter for total phenols, and nephelometric turbidity units for turbidity. See figure 2 for location of wells. QAS, quality assurance sample (see Quality Assurance section in text for explanation); <, concentration is less than the indicated reporting level]

\begin{tabular}{|c|c|c|c|c|}
\hline $\begin{array}{l}\text { Well } \\
\text { identifier }\end{array}$ & $\begin{array}{c}\text { Date } \\
\text { sampled } \\
(\mathrm{m} / \mathrm{d} / \mathrm{y})\end{array}$ & $\begin{array}{l}\text { Organic } \\
\text { carbon }\end{array}$ & Phenols & Turbidity \\
\hline QAS-8 & $11 / 2 / 90$ & 0.5 & 2 & 3.0 \\
\hline \multirow[t]{5}{*}{ NRF-1 } & $3 / 21 / 90$ & .2 & 4 & 3.2 \\
\hline & $6 / 19 / 90$ & .2 & 4 & .4 \\
\hline & $8 / 7 / 90$ & .5 & 3 & .3 \\
\hline & $10 / 2 / 90$ & .4 & $<1$ & .4 \\
\hline & $12 / 6 / 90$ & .5 & 1 & .4 \\
\hline NRF-2 & $3 / 21 / 90$ & .4 & $<1$ & .4 \\
\hline \multirow[t]{5}{*}{ QAS-2 } & $3 / 21 / 90$ & .3 & 3 & 1.1 \\
\hline & $6 / 19 / 90$ & .3 & 3 & .4 \\
\hline & $8 / 7 / 90$ & .4 & 2 & .3 \\
\hline & $10 / 2 / 90$ & .4 & $<1$ & .3 \\
\hline & $12 / 5 / 90$ & .6 & 6 & .6 \\
\hline \multirow[t]{5}{*}{ NRF-3 } & $3 / 21 / 90$ & .3 & 3 & .4 \\
\hline & $6 / 19 / 90$ & .2 & 3 & .3 \\
\hline & $8 / 7 / 90$ & .4 & 7 & .6 \\
\hline & $10 / 2 / 90$ & .5 & $<1$ & .3 \\
\hline & $12 / 6 / 90$ & .6 & $<1$ & .4 \\
\hline \multirow[t]{5}{*}{ NRF-4 } & $6 / 19 / 90$ & .3 & 4 & .2 \\
\hline & $8 / 7 / 90$ & .4 & 4 & .3 \\
\hline & $10 / 2 / 90$ & .5 & 1 & .5 \\
\hline & $12 / 5 / 90$ & .4 & 8 & .6 \\
\hline & $2 / 7 / 91$ & .3 & 4 & .5 \\
\hline QAS-12 & $2 / 7 / 91$ & .3 & 2 & .4 \\
\hline \multirow[t]{5}{*}{ USGS 12} & $8 / 6 / 90$ & .3 & $<1$ & .4 \\
\hline & $10 / 10 / 90$ & .4 & 1 & .7 \\
\hline & $12 / 11 / 90$ & .7 & $<1$ & .3 \\
\hline & $2 / 7 / 91$ & .3 & 2 & .4 \\
\hline & $4 / 11 / 91$ & .6 & $<1$ & .6 \\
\hline
\end{tabular}


Table 9.-Concentrations of total organic carbon and total phenols in water, and turbidity, Naval Reactors Facility and vicinity-Continued

\begin{tabular}{|c|c|c|c|c|}
\hline $\begin{array}{l}\text { Well } \\
\text { identifier }\end{array}$ & $\begin{array}{c}\text { Date } \\
\text { sampled } \\
(\mathrm{m} / \mathrm{d} / \mathrm{y})\end{array}$ & $\begin{array}{l}\text { Organic } \\
\text { carbon }\end{array}$ & Phenols & Turbidity \\
\hline USGS 15 & $8 / 6 / 90$ & 1.5 & 7 & 22 \\
\hline \multirow[t]{5}{*}{ QAS-6 } & $8 / 6 / 90$ & 2.2 & 5 & 59 \\
\hline & $10 / 9 / 90$ & .3 & 1 & .3 \\
\hline & $12 / 13 / 90$ & .2 & $<1$ & .3 \\
\hline & $2 / 11 / 91$ & $<.1$ & 2 & .3 \\
\hline & $4 / 12 / 91$ & $<.1$ & $<1$ & .3 \\
\hline \multirow[t]{5}{*}{ USGS 17} & $3 / 20 / 90$ & .1 & $<1$ & 1.0 \\
\hline & $6 / 7 / 90$ & .1 & 3 & .4 \\
\hline & $8 / 2 / 90$ & .1 & 1 & .3 \\
\hline & $10 / 10 / 90$ & .1 & 3 & 1.0 \\
\hline & $12 / 10 / 90$ & .2 & 1 & .7 \\
\hline \multirow[t]{2}{*}{ USGS 97} & $3 / 19 / 90$ & .4 & 1 & .4 \\
\hline & $6 / 7 / 90$ & .2 & 3 & .4 \\
\hline \multirow[t]{4}{*}{ QAS-3 } & $6 / 7 / 90$ & .2 & 3 & .3 \\
\hline & $8 / 1 / 90$ & .3 & 2 & .5 \\
\hline & $10 / 4 / 90$ & .5 & 1 & .3 \\
\hline & $12 / 7 / 90$ & .3 & 2 & .4 \\
\hline QAS-10 & $12 / 7 / 90$ & .4 & 1 & .2 \\
\hline \multirow[t]{3}{*}{ USGS 98} & $3 / 19 / 90$ & .1 & 1 & .2 \\
\hline & $6 / 5 / 90$ & .3 & 4 & .9 \\
\hline & $7 / 30 / 90$ & .2 & 2 & .5 \\
\hline \multirow[t]{3}{*}{ QAS-5 } & $7 / 30 / 90$ & .3 & 1 & .3 \\
\hline & $10 / 3 / 90$ & .2 & 2 & .3 \\
\hline & $12 / 7 / 90$ & .1 & 2 & .5 \\
\hline \multirow[t]{4}{*}{ USGS 99} & $3 / 20 / 90$ & .2 & $<1$ & .7 \\
\hline & $6 / 5 / 90$ & .3 & 4 & .6 \\
\hline & $8 / 1 / 90$ & .3 & 3 & .2 \\
\hline & $10 / 3 / 90$ & .4 & $<1$ & .4 \\
\hline \multirow[t]{2}{*}{ QAS-7 } & $10 / 3 / 90$ & .4 & $<1$ & .4 \\
\hline & $12 / 10 / 90$ & .3 & 2 & .3 \\
\hline
\end{tabular}


Table 9.-Concentrations of total organic carbon and total phenols in water, and turbidity, Naval Reactors Facility and vicinity-Continued

\begin{tabular}{llcrr}
\hline $\begin{array}{l}\text { Well } \\
\text { identifier }\end{array}$ & $\begin{array}{c}\text { Date } \\
\text { sampled } \\
(\mathrm{m} / \mathrm{d} / \mathrm{y})\end{array}$ & $\begin{array}{c}\text { Organic } \\
\text { carbon }\end{array}$ & Phenols & Turbidity \\
\hline \multirow{2}{*}{ USGS 102 } & $8 / 1 / 90$ & .3 & 2 & .8 \\
& $10 / 4 / 90$ & .4 & 1 & 1.1 \\
QAS-11 & $12 / 10 / 90$ & .4 & 1 & .6 \\
& $12 / 10 / 90$ & .3 & 1 & .7 \\
& $2 / 7 / 91$ & .4 & $<1$ & .3 \\
Water Supply & $4 / 11 / 91$ & .4 & & .3 \\
INEL-1 & & & $<1$ & .4 \\
& $3 / 19 / 90$ & .6 & 5 & 1.0 \\
& $6 / 5 / 90$ & .7 & 1 & .5 \\
& $7 / 30 / 90$ & .9 & 2 & 1.0 \\
QAS-9 & $10 / 3 / 90$ & .9 & 2 & .6 \\
& $12 / 7 / 90$ & 1.0 & 1 & .5 \\
\hline
\end{tabular}


Table 10.-Statistical parameters for dissolved nutrients, total organic carbon, total phenols, and turbidity, by well

IUnits are milligrams per liter for dissolved nutrients and total organic carbon, micrograms per liter for total phenols, and nephelometric turbidity units for turbidity. Values are derived from tables $8-9$. See figure 2 for location of wells. Quality assurance replicates were included in the statistical parameters. Mean and median sample size: includes all samples with concentrations greater than laboratory reporting level]

\begin{tabular}{lccc}
\hline & \multicolumn{3}{c}{ Statistical parameter } \\
\cline { 2 - 4 } & & & Mean and \\
Constituent & Minimum & Sample & median \\
size sample size
\end{tabular}

Nitrite plus nitrate

Organic carbon

Phenols

Turbidity

Nitrite plus nitrate

Organic carbon

Phenols

Turbidity

Nitrite plus nitrate

Organic carbon

Phenols

Turbidity

Ammonia

Ammonia plus organic nitrogen

Nitrite plus nitrate

Orthophosphate

Organic carbon

Phenols

Turbidity

$\begin{array}{rr}1.5 & \text { NRF-1 } \\ .2 & .6 \\ <1 & 4.5 \\ .3 & 3.2\end{array}$

NRF-1

\section{NRF-2}

$\begin{array}{rl}1.7 & 1.9 \\ .3 & .6 \\ <1 & 6 \\ .3 & 1.1\end{array}$

1.75
.4
3
.4

$\begin{array}{ll}1.8 & 6 \\ .4 & 6 \\ 4 & 6 \\ .5 & 6\end{array}$

6

6

4

NRF-3

$\begin{array}{rr}1.6 & 1.7 \\ .2 & .6 \\ <1 & 7 \\ .3 & .6\end{array}$

$\begin{array}{ccc}1.6 & 1.6 & 5 \\ .4 & .4 & 5 \\ 3 & 4 & 5 \\ .4 & .4 & 5\end{array}$

NRF-4

$<.(01$

$<.2$

1.8

.01

.3

1

.2

.03
1.1
1.9
.04
.5
8.6

.12
.5
1.8
.02
.35
4
.45

$\begin{array}{cc}.02 & 4 \\ .7 & 4 \\ 1.8 & 6 \\ .12 & 4 \\ .4 & 6 \\ 4 & 6 \\ .4 & 6\end{array}$

3
3
6
4
6
6
6

USGS 12

Ammonia plus organic nitrogen $<.2$

Nitrite plus nitrate

1.6

Orthophosphate
$<.(1) 1$
.3

1.8

.$(12$
.3
1.7
.12

$\begin{array}{cc}.3 & 4 \\ 1.7 & 5 \\ .(12 & 4\end{array}$

5

5

4

5 
Table 1().-Statistical parameters for dissolved nutrients, total organic carbon, total phenols, and turbidity, by well-Continued

\begin{tabular}{|c|c|c|c|c|c|c|}
\hline \multirow[b]{2}{*}{ Constituent } & \multicolumn{6}{|c|}{ Statistical parameter } \\
\hline & Minimum & Maximum & Median & Mean & $\begin{array}{l}\text { Sample } \\
\text { size }\end{array}$ & $\begin{array}{l}\text { Mean and } \\
\text { median } \\
\text { sample size }\end{array}$ \\
\hline \multicolumn{7}{|c|}{ USGS 12 (continued) } \\
\hline Organic carbon & .3 & .7 & .4 & .5 & 5 & 5 \\
\hline Turbidity & .3 & .7 & .4 & .5 & 5 & 5 \\
\hline \multicolumn{7}{|c|}{ USGS 15} \\
\hline Nitrite plus nitrate & .31 & 16 & .8 & 3.3 & 6 & 6 \\
\hline Organic carbon & $<.1$ & 2.2 & .9 & 1.0 & 6 & 4 \\
\hline Phenols & $<1$ & 7 & 3.5 & 4 & 6 & 4 \\
\hline Turbidity & .3 & 59 & .3 & 14 & 6 & 6 \\
\hline \multicolumn{7}{|c|}{ USGS 17} \\
\hline Nitrite plus nitrate & .30 & 1.6 & .30 & .56 & 5 & 5 \\
\hline Organic carbon & .1 & .2 & .1 & .1 & 5 & 5 \\
\hline Phenols & $<1$ & 3 & 2 & 2 & 5 & 4 \\
\hline Turbidity & .3 & 1.0 & .7 & .7 & 5 & 5 \\
\hline \multicolumn{7}{|c|}{ USGS 97} \\
\hline Nitrite plus nitrate & 1.8 & 2.0 & 1.8 & 1.8 & 7 & 7 \\
\hline Orthophosphate & .02 & .03 & .02 & .02 & 3 & 3 \\
\hline Organic carbon & .2 & .5 & .3 & .3 & 7 & 7 \\
\hline Phenols & 1 & 3 & 2 & 2 & 7 & 7 \\
\hline Turbidity & .2 & .5 & .4 & .4 & 7 & 7 \\
\hline \multicolumn{7}{|c|}{ USGS 98} \\
\hline Nitrite plus nitrate & 1.0 & 3.0 & 1.1 & 1.4 & 6 & 6 \\
\hline Organic carbon & .1 & .3 & .2 & .2 & 6 & 6 \\
\hline Phenols & 1 & 4 & 2 & 2 & 6 & 6 \\
\hline Turbidity & .2 & .9 & .4 & .4 & 6 & 6 \\
\hline \multicolumn{7}{|c|}{ USGS 99} \\
\hline Ammonia plus organic nitrogen & .3 & .5 & .3 & .4 & 3 & 3 \\
\hline Nitrite plus nitrate & 1.5 & 1.6 & 1.5 & 1.5 & 6 & 6 \\
\hline Organic carbon & .2 & .4 & .3 & .3 & 6 & 6 \\
\hline Phenols & $<1$ & 4 & 3 & 3 & 6 & 3 \\
\hline Turbidity & .2 & .7 & .4 & .4 & 6 & 6 \\
\hline
\end{tabular}


Table 10.-Statistical parameters for dissolved nutrients, total organic carbon, total phenols, and turbidity, by well - Continued

Statistical parameter

\begin{tabular}{|c|c|c|c|c|c|c|}
\hline Constituent & Minimum & Maximum & Median & Mean & $\begin{array}{c}\text { Sample } \\
\text { size }\end{array}$ & $\begin{array}{l}\text { Mean and } \\
\text { median } \\
\text { sample size }\end{array}$ \\
\hline
\end{tabular}

Ammonia plus organic nitrogen $<.2$

Nitrite plus nitrate

USGS $1(2$

Orthophosphate

Organic carbon

Phenols

.5

.30)

.01

Turbidity

$<1.3$

1.7

.12

.4

.3

2

1.1

$\begin{array}{ccc}.4 & .4 & 5 \\ 1.7 & 1.4 & 6 \\ .12 & .02 & 5 \\ .4 & .4 & 6 \\ 1 & 1 & 6 \\ .65 & .6 & 6\end{array}$

3

6

5

6

4

6

Water Supply INEL-1

Ammonia plus organic nitrogen

Nitrite plus nitrate

$\begin{array}{rl}.3 & 1.2 \\ 5.0 & 5.6 \\ .6 & 1.6 \\ <1 & 5 \\ .4 & 1.0\end{array}$

.4

5.45

$.6 \quad 3$

$5.4 \quad 6$

3

Organic carbon

Phenols

Turbidity

1.0

$\begin{array}{lll}.9 & 1.0 & 6\end{array}$

6

6

$\begin{array}{llll}2 & 2 & 6 & 5\end{array}$

$\begin{array}{lll}.55 & .7 & 6\end{array}$

6

Ammonia $<.(0) 1$

Ammonia plus organic nitrogen $<.2$

Nitrite plus nitrate

.30

Orthophosphate

$<.01$

Organic carbon

Phenols

$<.1$

$<1$

Turbidity

.2

All wells

.03

1.2

16

.04

2.2

8

59$$
.02
$$

.4

.02

33

12

$.4 \quad 36$

22

$\begin{array}{lll}1.7 & 2.0 & 69\end{array}$

69

$\begin{array}{lll}.12 & .12 & 36\end{array}$

24

$\begin{array}{lll}.3 & .4 & 69\end{array}$

67

2

3

69

52

$\begin{array}{lll}.4 & 1.7 & 69\end{array}$

69 
Table 11.-Extractable acid and base/neutral organic compounds for which water samples were analyzed

IAnalyses were performed by the U.S. Geological Survey's National Water Quality Laboratory using gas chromatography to separate the compounds and mass spectrometry and flame ionization for identification and quantification. Initial extraction was with methylene chloride. Reporting levels are in micrograms per liter (Pritt and Jones, 1989)|

\begin{tabular}{|c|c|c|c|}
\hline Compound & $\begin{array}{l}\text { Reporting } \\
\text { level }\end{array}$ & Compound & $\begin{array}{c}\text { Reporting } \\
\text { level }\end{array}$ \\
\hline Acenaphthene & $5 .()$ & 2,4-Dinitrophenol & 20.0 \\
\hline Acenaphthylene & $5 .()$ & 2,4-Dinitrotoluene & 5.0 \\
\hline Anthracene & 5.0 & 2,6-Dinitrotoluene & 5.0 \\
\hline Benzo (a) anthracene & 10.0 & Di-n-octylphthalate & 10.0 \\
\hline Benzo (b) fluoranthene & $10 .()$ & bis (2-Ethylhexyl) phthalate & 5.0 \\
\hline Benzo (k) fluoranthene & $10 .(0$ & Fluoranthene & 5.0 \\
\hline Benzo $(g, h, i)$ perylene & 10.0 & Fluorene & 5.0 \\
\hline Benzo (a) pyrene & 10.0 & Hexachlorobenzene & 5.0 \\
\hline 4-Bromophenyl phenyl ether & 5.0 & Hexachlorobutadiene & $5 .()$ \\
\hline Butyl benzyl phthalate & $5 .()$ & Hexachlorocyclopentadiene & 5.0 \\
\hline bis (2-Chloroethoxy) methane & 5.0 & Hexachloroethane & $5.1)$ \\
\hline bis (2-Chloroethyl) ether & $5 .()$ & Indeno $(1,2,3-c d)$ pyrene & 10.0 \\
\hline bis (2-Chloroisopropyl) ether & 5.0 & Isophorone & 5.0 \\
\hline 4-Chloro-3-methylphenol & 30.0 & 2-Methyl-4,6-dinitrophenol & 30.0 \\
\hline 2-Chloronaphthalene & $5 .()$ & Naphthalene & 5.0 \\
\hline 2-Chlorophenol & $5 .()$ & Nitrobenzene & 5.0 \\
\hline 4-Chlorophenyl phenyl ether & $5 .()$ & 2-Nitrophenol & 5.0 \\
\hline Chrysene & 10.0 & 4-Nitrophenol & $3(0.0$ \\
\hline Dibenzo $(\mathrm{a}, \mathrm{h})$ anthracene & 10.0 & n-Nitrosodimethylamine & 5.0 \\
\hline 1,2-Dichlorobenzene & 5.0 & n-Nitrosodi-n-propylamine & 5.0 \\
\hline 1,3-Dichlorobenzene & 5.0 & n-Nitrosodiphenylamine & $5 .()$ \\
\hline 1,4-Dichlorobenzene & $5 .()$ & Pentachlorophenol & 30.0 \\
\hline 2,4-Dichlorophenol & 5.0 & Phenanthrene & 5.0 \\
\hline Diethyl phthalate & 5.0 & Phenol & 5.0 \\
\hline Dimethyl phthalate & 5.0 & Pyrene & 5.0 \\
\hline 2,4-Dimethylphenol & 5.0 & 1,2,4-Trichlorobenzene & 5.0 \\
\hline Di-n-butyl phthalate & 5.0 & 2,4,6-Trichlorophenol & 20.0 \\
\hline
\end{tabular}



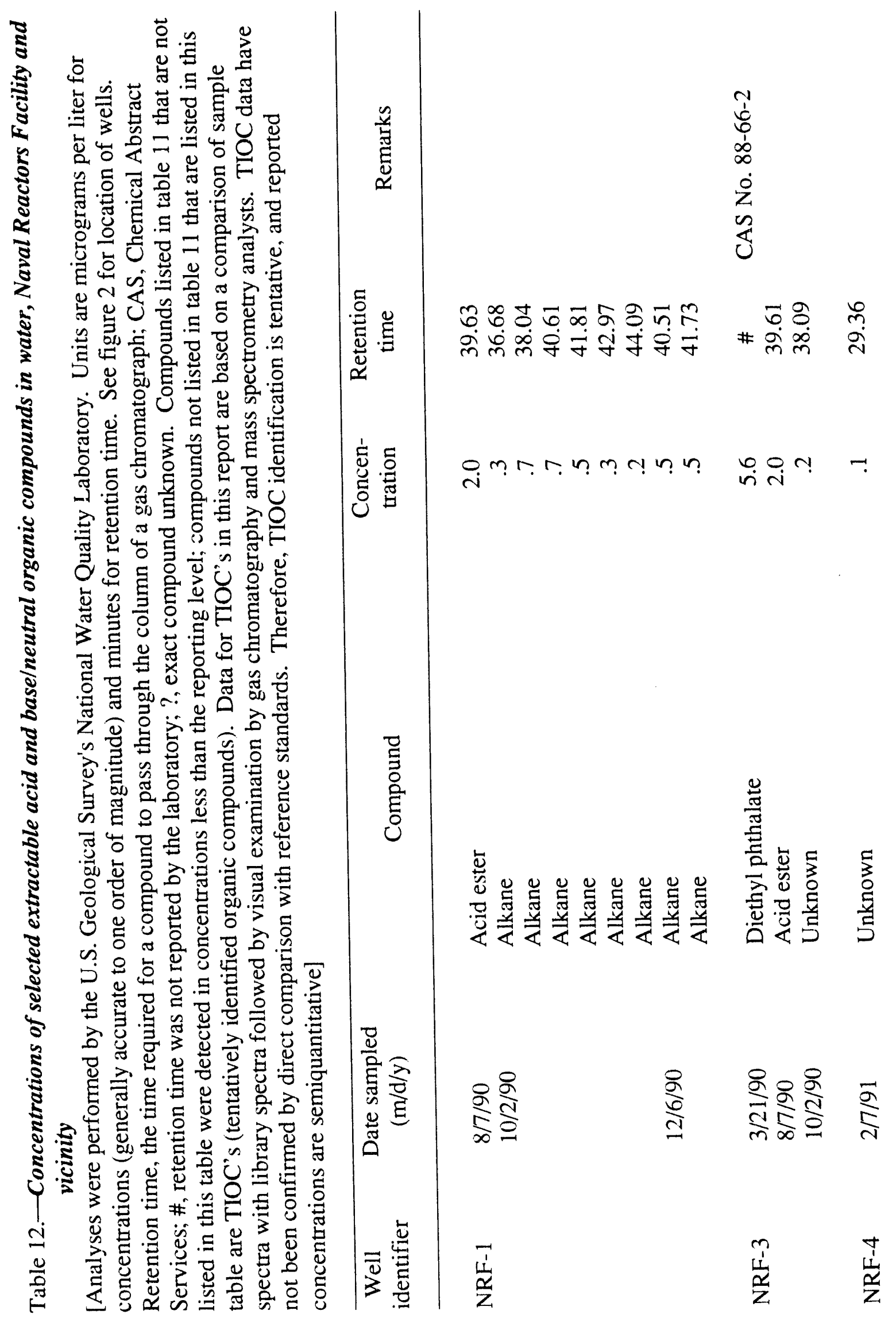


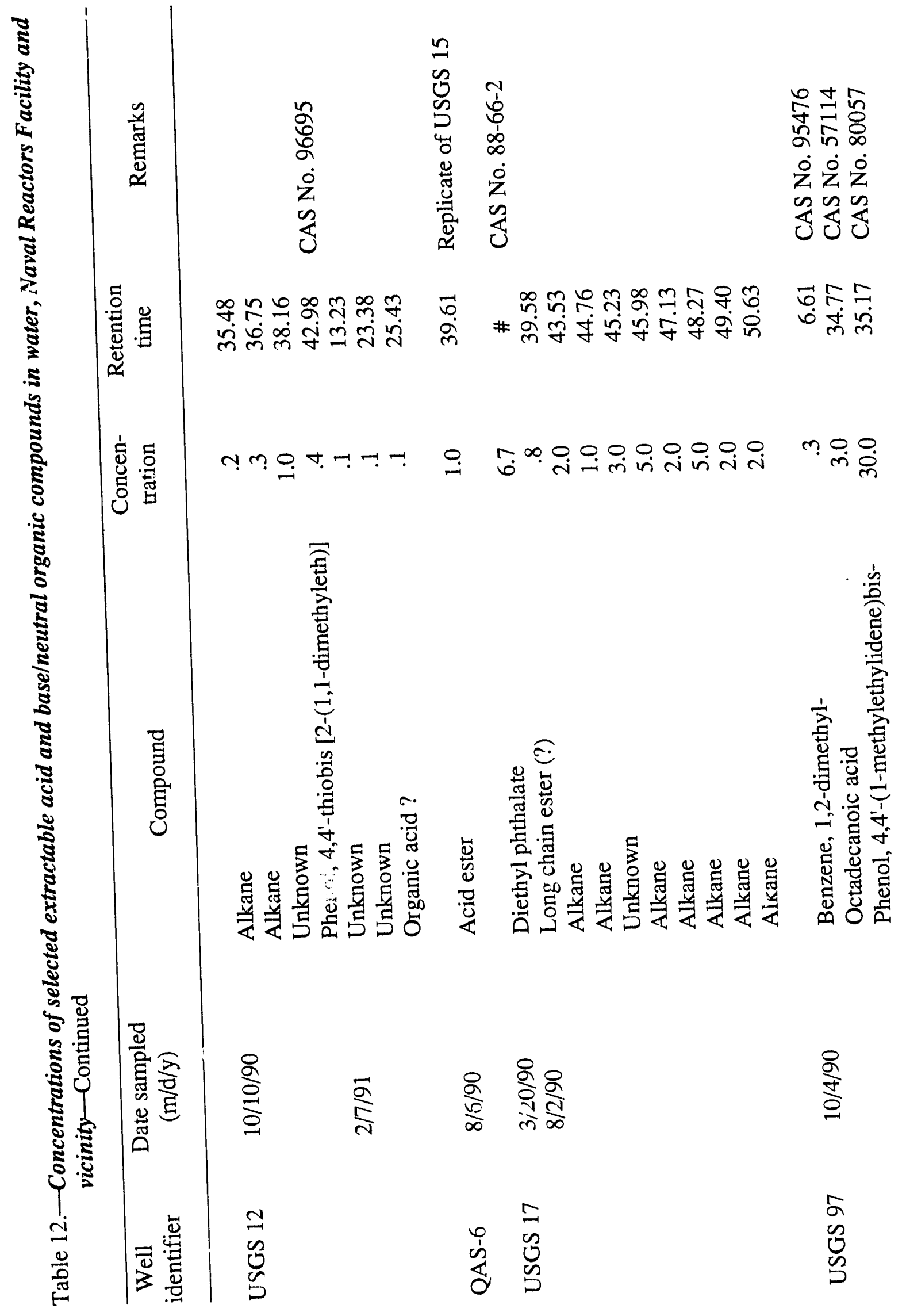




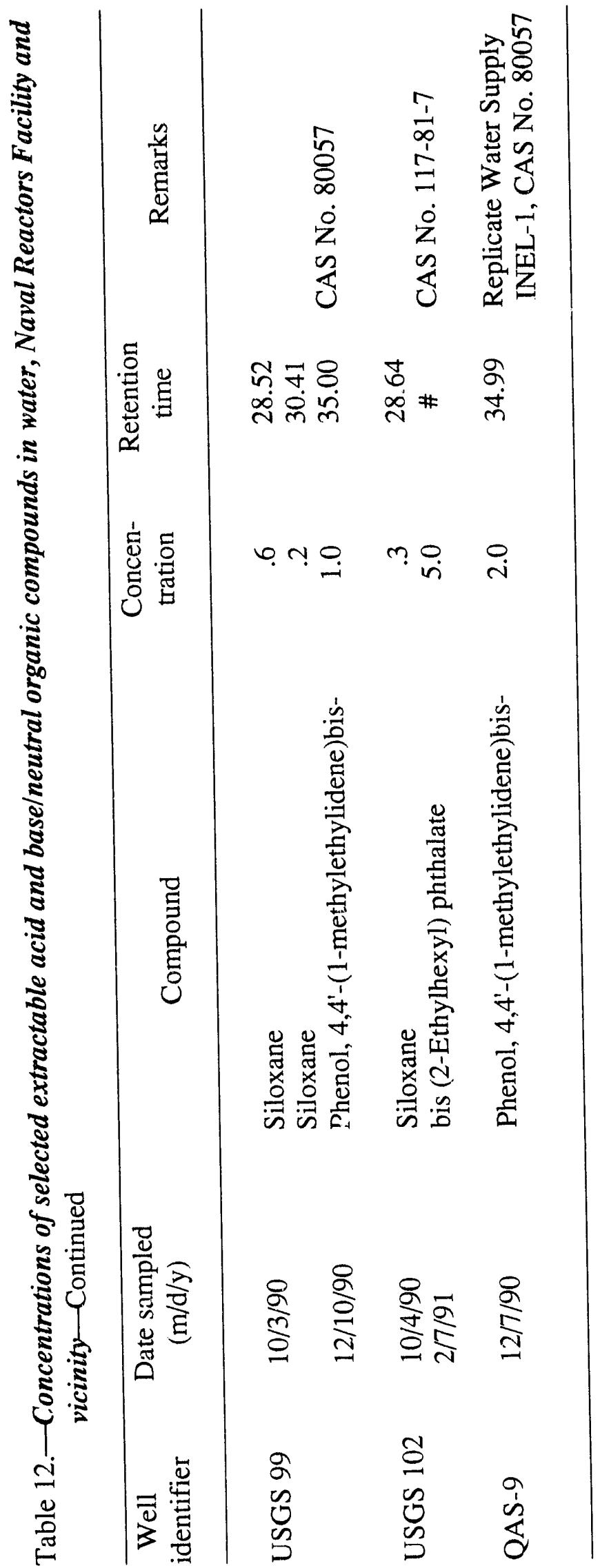


Table 13.-Pesticides for which water samples were analyzed

[Reporting levels are from Pritt and Jones (1989). Units are in micrograms per liter]

\begin{tabular}{|c|c|c|c|}
\hline \multicolumn{4}{|c|}{ Organochlorine insecticides } \\
\hline Insecticide & $\begin{array}{c}\text { Reporting } \\
\text { level }\end{array}$ & Insecticide & $\begin{array}{c}\text { Reporting } \\
\text { level }\end{array}$ \\
\hline Aldrin & 0.01 & Heptachlor & 0.01 \\
\hline Chlordane & 1.0 & Heptachlor epoxide & .01 \\
\hline DDD & .01 & Lindane & .01 \\
\hline DDE & .01 & Methoxychlor & .01 \\
\hline DDT & .01 & Mirex & .01 \\
\hline Dieldrin & .01 & Perthane & .1 \\
\hline Endosulfan & .01 & Toxaphene & 1.0 \\
\hline Endrin & .01 & & \\
\hline
\end{tabular}

\begin{tabular}{|c|c|c|c|}
\hline \multicolumn{4}{|c|}{ Gross polychlorinated compounds } \\
\hline \multicolumn{3}{|l|}{ Compound } & level \\
\hline \multirow{2}{*}{\multicolumn{3}{|c|}{$\begin{array}{l}\text { Gross polychlorinated biphenyls (PCB) } \\
\text { Gross polychlorinated naphthalenes (PCN) }\end{array}$}} & 0.1 \\
\hline & & & .1 \\
\hline \multicolumn{4}{|c|}{ Chlorophenoxy acid herbicides } \\
\hline \multicolumn{3}{|c|}{ Reporting } & $\begin{array}{l}\text { Reporting } \\
\text { level }\end{array}$ \\
\hline 2,4-D & 0.01 & Silvex & 0.01 \\
\hline 2,4-DP & .01 & $2,4,5-\mathrm{T}$ & .01 \\
\hline
\end{tabular}


Table 14.-Concentrations of gross alpha-particle radioactivity in water, Naval Reactors Facility and vicinity

[Analyses were performed by the U.S. Geological Survey's National Water Quality Laboratory using a residue procedure. Analytical results and uncertainties-for example, 4.38 \pm 0.66 - in indicated units. Analytical uncertainties are reported as $1 \mathbf{s}$. Concentrations that exceed the reporting level of 3 times the $1 \mathrm{~s}$ value are shown in boldface type. See figure 2 for location of wells. QAS, quality assurance sample (see Quality Assurance section in text for explanation); $\mu \mathrm{g} / \mathrm{L}$, microgram per liter; $\mathrm{pCi} / \mathrm{L}$, picocurie per liter. Raw field samples were processed in laboratory prior to analyses]

\begin{tabular}{|c|c|c|c|c|c|}
\hline \multirow[b]{2}{*}{$\begin{array}{c}\text { Well } \\
\text { identifier }\end{array}$} & \multirow{2}{*}{$\begin{array}{c}\text { Date } \\
\text { sampled } \\
(\mathrm{m} / \mathrm{d} / \mathrm{y})\end{array}$} & \multicolumn{2}{|c|}{ Dissolved } & \multicolumn{2}{|c|}{ Suspended } \\
\hline & & $\begin{array}{l}\text { as uranium } \\
(\mu \mathrm{g} / \mathrm{L})\end{array}$ & $\begin{array}{l}\text { as thorium-230 } \\
(\mathrm{pCi} / \mathrm{L})\end{array}$ & $\begin{array}{l}\text { as uranium } \\
(\mu \mathrm{g} / \mathrm{L})\end{array}$ & $\begin{array}{l}\text { as thorium-230 } \\
(\mathrm{pCi} / \mathrm{L})\end{array}$ \\
\hline QAS-8 & $11 / 2 / 90$ & $0.084 \pm 0.150$ & $0.057 \pm 0.102$ & $-0.236 \pm 0.144$ & $-(0.126 \pm 0.080$ \\
\hline \multirow[t]{5}{*}{ NRF-1 } & $3 / 21 / 90$ & $4.38 \pm 0.66$ & $2.97 \pm 0.457$ & $-.076 \pm 0.104$ & $-.04(0 \pm 0.056$ \\
\hline & $6 / 19 / 90$ & $3.92 \pm 0.62$ & $2.79 \pm 0.448$ & $.103 \pm 0.208$ & $.060 \pm 0.122$ \\
\hline & $8 / 7 / 90$ & $4.47 \pm 0.66$ & $3.11 \pm 0.456$ & $-.038 \pm 0.178$ & $-.020 \pm 0.095$ \\
\hline & $10 / 2 / 90$ & $3.62 \pm 0.60$ & $2.52 \pm 0.422$ & $.157 \pm 0.198$ & $.088 \pm 0.112$ \\
\hline & $12 / 6 / 90$ & $4.94 \pm 0.68$ & $3.42 \pm 0.476$ & $.094 \pm 0.228$ & .05()$\pm 0.122$ \\
\hline NRF-2 & $3 / 21 / 90$ & $4.25 \pm() .66$ & $2.86 \pm 0.450$ & $.273 \pm(0.230)$ & $.143 \pm 0.121$ \\
\hline \multirow[t]{5}{*}{ QAS-2 } & $3 / 21 / 90$ & $4.47 \pm 0.72$ & $2.75 \pm 0.471$ & $.038 \pm 0.156$ & 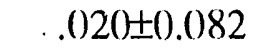 \\
\hline & $6 / 19 / 90$ & $2.76 \pm 0.54$ & $1.92 \pm 0.378$ & $-.009 \pm(0) .220$ & $-.005 \pm 0.128$ \\
\hline & $8 / 7 / 90$ & $5.05 \pm 0.70$ & $3.57 \pm 0.50$ & $-.243 \pm 0.167$ & $-.132 \pm(0.094$ \\
\hline & $10 / 2 / 90$ & $5.17 \pm 0.70$ & $3.72 \pm 0.500$ & $.048 \pm(0.220)$ & $.026 \pm(0.120)$ \\
\hline & $12 / 5 / 90$ & $4.26 \pm 0.64$ & $3.05 \pm 0.457$ & $-.018 \pm(0.121$ & $-.010 \pm(0.064$ \\
\hline \multirow[t]{5}{*}{ NRF-3 } & $3 / 21 / 90$ & $3.82 \pm(0.60$ & $2.51 \pm 0.406$ & $.129 \pm() .154$ & $.068 \pm 0.082$ \\
\hline & $6 / 19 / 90$ & $3.51 \pm(0.60$ & $2.55 \pm 0.438$ & $-.037 \pm(0.170$ & $-.021 \pm(0.100$ \\
\hline & $8 / 7 / 90$ & $2.99 \pm 0.53$ & $2.09 \pm 0.372$ & $-.218 \pm(0.148$ & $-.118 \pm(0.082$ \\
\hline & $10 / 2 / 90$ & $4.65 \pm 0.68$ & $3.27 \pm 0.478$ & $-.1(04 \pm(0.204$ & $-.057 \pm 0.112$ \\
\hline & $12 / 6 / 90$ & $4.00 \pm 0.61$ & $2.78 \pm 0.428$ & $-.048 \pm 0.198$ & $-.025 \pm 0.106$ \\
\hline \multirow[t]{5}{*}{ NRF-4 } & $6 / 19 / 90$ & $4.40 \pm 0.68$ & $3.19 \pm 0.492$ & $.281 \pm(0.239$ & $.167 \pm 0.146$ \\
\hline & $8 / 7 / 90$ & $4.23 \pm 0.64$ & $2.93 \pm 0.447$ & $0 \pm 0.214$ & $(0 \pm 0.112$ \\
\hline & $10 / 2 / 90$ & $3.27 \pm 0.54$ & $2.31 \pm 0.385$ & -.(088土(0.172 & $-.056 \pm 0.110$ \\
\hline & $12 / 5 / 90$ & $3.63 \pm(0.59$ & $2.24 \pm 0.388$ &.$-(076 \pm(0) .136$ &.$-(04() \pm() .073$ \\
\hline & $2 / 7 / 91$ & $3.95 \pm(0.60$ & $2.72 \pm 0.409$ & $.037 \pm(0.108$ & $.021 \pm 0.063$ \\
\hline QAS-12 & $2 / 7 / 91$ & $4.40 \pm 0.64$ & $3.15 \pm 0.458$ & .2() $9 \pm 0.187$ & $.122 \pm 0.112$ \\
\hline
\end{tabular}


Table 14.-Concentrations of gross alpha-particle radioactivity in water, Naval Reactors Facility and vicinity-Continued

\begin{tabular}{|c|c|c|c|c|c|}
\hline \multirow[b]{2}{*}{$\begin{array}{l}\text { Well } \\
\text { identifier }\end{array}$} & \multirow{2}{*}{$\begin{array}{c}\text { Date } \\
\text { sampled } \\
(\mathrm{m} / \mathrm{d} / \mathrm{y})\end{array}$} & \multicolumn{2}{|c|}{ Dissolved } & \multicolumn{2}{|c|}{ Suspended } \\
\hline & & $\begin{array}{l}\text { as uranium } \\
(\mu \mathrm{g} / \mathrm{L})\end{array}$ & $\begin{array}{l}\text { as thorium-230 } \\
(\mathrm{pCi} / \mathrm{L})\end{array}$ & $\begin{array}{l}\text { as uranium } \\
(\mu \mathrm{g} / \mathrm{L})\end{array}$ & $\begin{array}{l}\text { as thorium-230 } \\
\qquad(\mathrm{pCi} / \mathrm{L})\end{array}$ \\
\hline \multirow[t]{5}{*}{ USGS 12} & $8 / 6 / 90$ & $4.27 \pm 0.65$ & $3.07 \pm 0.467$ & $-.305 \pm 0.148$ & $-.166 \pm 0.086$ \\
\hline & $10 / 10 / 90$ & $4.45 \pm 10.66$ & $3.09 \pm 0.459$ & $.084 \pm 0) .128$ & $.046 \pm 0.070$ \\
\hline & $12 / 11 / 90$ & $4.45 \pm 0.64$ & $3.07 \pm 0.451$ & $-.142 \pm 1) .172$ & $-.075 \pm 0.092$ \\
\hline & $2 / 7 / 91$ & $2.54 \pm 0.416$ & $2.55 \pm 0.419$ & $.035 \pm(0.102$ & $.022 \pm 0.066$ \\
\hline & $4 / 11 / 91$ & $3.59 \pm 0.57$ & $2.48 \pm 0.390$ & $-.063 \pm 0.100$ & $-.038 \pm 0.060$ \\
\hline USGS 15 & $8 / 6 / 90$ & $3.48 \pm 0.58$ & $2.44 \pm 0.407$ & $1.76 \pm 0.56$ & $2.20 \pm 0.71$ \\
\hline \multirow[t]{5}{*}{ QAS-6 } & $8 / 6 / 90$ & $2.41 \pm 0.52$ & $1.51 \pm 0.336$ & $9.10 \pm 3.00$ & $7.28 \pm 2.62$ \\
\hline & $10 / 9 / 90$ & $3.10 \pm 0.56$ & $1.93 \pm 0.364$ & .36()$\pm 0.250$ & $.189 \pm 0.132$ \\
\hline & $12 / 13 / 90$ & $2.55 \pm 0.49(1)$ & $1.79 \pm 0.345$ & $-.009 \pm 0.087$ & $-.005 \pm 0.047$ \\
\hline & $2 / 11 / 91$ & $2.26 \pm 0.477$ & $1.40 \pm 0.306$ & $.280 \pm 0.238$ & $.156 \pm 0.134$ \\
\hline & $4 / 12 / 91$ & $2.34 \pm 0.465$ & $1.61 \pm 0.323$ & $-.018 \pm() .122$ & $-.010 \pm 0.068$ \\
\hline \multirow[t]{5}{*}{ USGS 17} & $3 / 20 / 90$ & $2.97 \pm 0.56$ & $2.05 \pm 0.387$ & $-.037 \pm 0.122$ & $-.020 \pm 0.066$ \\
\hline & $6 / 7 / 90$ & $3.43 \pm 0.56$ & $2.34 \pm 0.391$ & $-.037 \pm 0.174$ & $-.022 \pm 0.101$ \\
\hline & $8 / 2 / 90$ & $1.67 \pm 0.424$ & $1.04 \pm 0.270$ & $-.030 \pm 0.190$ & $-.018 \pm 0.115$ \\
\hline & $10 / 10 / 90$ & $2.59 \pm 0.492$ & $1.85 \pm 0.352$ & $.134 \pm(0.256$ & $.071 \pm 0.136$ \\
\hline & $12 / 10 / 90$ & $2.97 \pm 0.54$ & $1.85 \pm 0.352$ & $.178 \pm 0.158$ & $.096 \pm 0.088$ \\
\hline \multirow[t]{2}{*}{ USGS 97} & $3 / 19 / 90$ & $4.54 \pm 0.69$ & $3.08 \pm 0.476$ & $-.018 \pm 0.084$ & $-.010 \pm 0.046$ \\
\hline & $6 / 7 / 90$ & $4.05 \pm 0.60$ & $2.80 \pm 0.424$ & $.036 \pm 0.224$ & $.022 \pm 0.137$ \\
\hline \multirow[t]{4}{*}{ QAS-3 } & $6 / 7 / 90$ & $4.22 \pm 0.64$ & $2.60 \pm 0.421$ & ()$\pm(1) .195$ & $0 \pm 0.121$ \\
\hline & $8 / 1 / 90$ & $3.38 \pm 0.56$ & $2.33 \pm 0.394$ & $-.082 \pm(1.229$ &.$-(144 \pm 0.125$ \\
\hline & $1(0 / 4 / 90$ & $3.21 \pm 0.54$ & $2.24 \pm 0.383$ & $-.122 \pm() .118$ & $-.066 \pm 0.064$ \\
\hline & $12 / 7 / 90$ & $2.64 \pm 0.493$ & $1.82 \pm 0.341$ & $-.082 \pm 0.157$ & $-.044 \pm 0.085$ \\
\hline QAS-10 & $12 / 7 / 90$ & $3.86 \pm 0.60$ & $2.76 \pm 0.434$ & $.084 \pm 0.126$ & $.046 \pm 0.071$ \\
\hline \multirow[t]{3}{*}{ USGS 98} & $3 / 19 / 90$ & $3.85 \pm 0.65$ & $2.69 \pm 0.458$ & $-(037 \pm 0.122$ & $-.020 \pm 0.066$ \\
\hline & $6 / 5 / 90$ & $3.48 \pm 0.57$ & $2.38 \pm 0.398$ &.$-(199 \pm 0.195$ & $-.059 \pm 0.117$ \\
\hline & $7 / 30 / 90$ & $3.44 \pm 0.62$ & $2.16 \pm(0.401$ & $.037 \pm 0.232$ & $.020 \pm 0.129$ \\
\hline \multirow[t]{3}{*}{ QAS-5 } & $7 / 30 / 90$ & $2.60 \pm 0.51$ & $1.81 \pm 0.359$ & ()$\pm() .214$ & $0 \pm 0.112$ \\
\hline & $10 / 3 / 90$ & $3.17 \pm 0.54$ & $2.26 \pm 0.386$ & $-.137 \pm(1) .166$ & $-.074 \pm 0.090$ \\
\hline & $12 / 7 / 90$ & $2.64 \pm 0.492$ & $1.81 \pm 0.342$ & $-.138 \pm 0.168$ & $-.078 \pm 0.096$ \\
\hline
\end{tabular}


Table 14.-Concentrations of gross alpha-particle radioactivity in water, Naval Reactors Facility and vicinity-Continued

\begin{tabular}{|c|c|c|c|c|c|}
\hline \multirow[b]{2}{*}{$\begin{array}{l}\text { Well } \\
\text { identifier }\end{array}$} & \multirow{2}{*}{$\begin{array}{c}\text { Date } \\
\text { sampled } \\
(\mathrm{m} / \mathrm{d} / \mathrm{y})\end{array}$} & \multicolumn{2}{|c|}{ Dissolved } & \multicolumn{2}{|c|}{ Suspended } \\
\hline & & $\begin{array}{l}\text { as uranium } \\
(\mu \mathrm{g} / \mathrm{L})\end{array}$ & $\begin{array}{l}\text { as thorium-230 } \\
(\mathrm{pCi} / \mathrm{L})\end{array}$ & $\begin{array}{l}\text { as uranium } \\
(\mu g / L)\end{array}$ & $\begin{array}{l}\text { as thorium-230 } \\
\qquad(\mathrm{pCi} / \mathrm{L})\end{array}$ \\
\hline \multirow[t]{4}{*}{ USGS 99} & $3 / 20 / 90$ & $3.70 \pm 0.64$ & $2.26 \pm 0.41$ & $.115 \pm 0.182$ & $.060 \pm 0.096$ \\
\hline & $6 / 5 / 90$ & $3.72 \pm 0.58$ & $2.57 \pm 0.404$ & $.028 \pm 0.137$ & $.016 \pm 0.082$ \\
\hline & $8 / 1 / 90$ & $4.16 \pm 0.62$ & $2.87 \pm 0.438$ & $-.176 \pm(0.208$ & $-.094 \pm 0.112$ \\
\hline & $10 / 3 / 90$ & $3.31 \pm 0.56$ & $2.30 \pm 0.390$ & $-.0(1) 9 \pm 0.224$ & $-.005 \pm 0.124$ \\
\hline \multirow[t]{2}{*}{ QAS-7 } & $10 / 3 / 90$ & $3.91 \pm 0.61$ & $2.71 \pm 0.425$ & $.081 \pm 0.232$ & $.049 \pm 0.141$ \\
\hline & $12 / 10 / 90$ & $2.87 \pm 10.54$ & $2.08 \pm 0.388$ & $.115 \pm 0.194$ & $.062 \pm 0.106$ \\
\hline \multirow[t]{3}{*}{ USGS 102} & $8 / 1 / 90$ & $3.32 \pm 0.58$ & $2.40 \pm 0.416$ & $-.118 \pm 0.198$ & $-.064 \pm 0.109$ \\
\hline & $10 / 4 / 90$ & $4.24 \pm 10.63$ & $2.92 \pm 0.442$ & $-.243 \pm(1) .167$ & $-.132 \pm 0.094$ \\
\hline & $12 / 10 / 90$ & $3.8 .3 \pm 0.60$ & $2.63 \pm 0.415$ & $.009 \pm 0.178$ & $.005 \pm 0.102$ \\
\hline \multirow[t]{3}{*}{ QAS-11 } & $12 / 10 / 90$ & $4.27 \pm 0.64$ & $2.97 \pm 0.444$ & $-.245 \pm 0.183$ & $-.144 \pm 0.110$ \\
\hline & $2 / 7 / 91$ & $4.07 \pm 0.62$ & $2.84 \pm 0.437$ & $-.084 \pm 0.160$ & $-.050 \pm 0.094$ \\
\hline & $4 / 11 / 91$ & $3.56 \pm 0.59$ & $2.49 \pm 0.414$ & $-.181 \pm 0.134$ & $-.100 \pm 0.074$ \\
\hline \multicolumn{6}{|c|}{ Water Supply } \\
\hline \multirow[t]{5}{*}{ INEL-1 } & $3 / 19 / 90$ & $3.51 \pm 0.63$ & $2.16 \pm 0.408$ & $-.281 \pm 0.187$ & $-.151 \pm 0.104$ \\
\hline & $6 / 5 / 90$ & $4.16 \pm 0.62$ & $2.96 \pm 0.437$ & $.153 \pm 0.192$ & $.093 \pm 0.118$ \\
\hline & $7 / 30 / 90$ & $4.76 \pm 0.72$ & $2.98 \pm 10.474$ & $-.185 \pm 0.188$ & $-.098 \pm 0.100$ \\
\hline & $10 / 3 / 90$ & $2.47 \pm 0.489$ & $1.53 \pm 0.314$ & $-.139 \pm 1) .168$ & $-.078 \pm 0.096$ \\
\hline & $12 / 7 / 90$ & $3.58 \pm 0.60$ & $2.23 \pm 0.389$ & $-.293 \pm 0.172$ & $-.168 \pm 0.103$ \\
\hline QAS-9 & $12 / 7 / 90$ & $3.86 \pm 0.60$ & $2.67 \pm 0.414$ & $.048 \pm 0.220$ & $.025 \pm 0.116$ \\
\hline
\end{tabular}


Table 15.-Statistical parameters for gross alpha-particle radioactivity expressed as uranium and thorium-230, by well

[Units are micrograms per liter for uranium and picocuries per liter for thorium-230. Values are derived from table 14. See figure 2 for location of wells. Quality assurance replicates are included in the statistical parameters]

\begin{tabular}{lllclc}
\hline & \multicolumn{3}{c}{ Statistical parameter } & & Sample \\
\cline { 2 - 4 } Constituent & Minimum & Maximum & Median & Mean & size
\end{tabular}

Uranium (dissolved)
Thorium-230 (dissolved)
Uranium (suspended)
Thorium-230 (suspended)

Uranium (dissolved)

Thorium-230 (dissolved)

Uranium (suspended)

Thorium-230 (suspended)

Uranium (dissolved)

Thorium-230 (dissolved)

Uranium (suspended)

Thorium-230 (suspended)

Uranium (dissolved)

Thorium-230 (dissolved)

Uranium (suspended)

Thorium-230 (suspended)

Uranium (dissolved)

Thorium-230 (dissolved)

Uranium (suspended)

Thorium-230 (suspended)

Uranium (dissolved)

Thorium-230 (dissolved)

Uranium (susperided)

Thorium-230 (suspended)
NRF-1

$\begin{array}{lllll}3.62 \pm 0.60 & 4.94 \pm 0.68 & 4.38 \pm 0.66 & 4.27 \pm 0.23 & 5 \\ 2.52 \pm 0.422 & 3.42 \pm 0.476 & 2.97 \pm 0.457 & 2.96 \pm 0.151 & 5 \\ -.076 \pm 0.104 & .157 \pm 0.198 & .094 \pm 0.228 & .048 \pm 0.045 & 5 \\ -.040 \pm 0.056 & .088 \pm 0.112 & .050 \pm 0.122 & .028 \pm 0.025 & 5\end{array}$

NRF-2

$\begin{array}{lllll}2.76 \pm 0.54 & 5.17 \pm 0.70 & 4.365 \pm 0.482 & 4.33 \pm 0.35 & 6 \\ 1.92 \pm 0.378 & 3.72 \pm 0.5(00 & 2.955 \pm 0.321 & 2.98 \pm 0.264 & 6 \\ -.243 \pm 0.167 & .273 \pm 0.230 & .0145 \pm 0.135 & .015 \pm 0.067 & 6 \\ -.132 \pm 0.094 & .143 \pm 0.121 & .0075 \pm 0.076 & .007 \pm 0.036 & 6\end{array}$

NRF-3

$\begin{array}{lllll}2.99 \pm 0.53 & 4.65 \pm 0.68 & 3.82 \pm 0.60 & 3.79 \pm 0.27 & 5 \\ 2.09 \pm 0.372 & 3.27 \pm 0.478 & 2.55 \pm 0.438 & 2.64 \pm 0.193 & 5 \\ -.218 \pm 0.148 & .129 \pm(0.154 & -.048 \pm 0.198 & -.056 \pm 0.056 & 5 \\ -.118 \pm 0.082 & .068 \pm(0.082 & -.025 \pm 0.106 & -.031 \pm 0.030 & 5\end{array}$

\section{NRF-4}

$3.27 \pm 0.54$

$2.24 \pm 0.388$

4.4()$\pm 0.64$

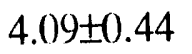

$3.98 \pm 0.19 \quad 6$

$3.19 \pm() .492 \quad 2.825 \pm(0.303$

$2.76 \pm 0.167 \quad 6$

$-.088 \pm 0.172$

$.281 \pm(0.239$

$.0185 \pm 0.120$

$.060 \pm 0.062 \quad 6$

$-.056 \pm 0.110$

$.167 \pm 0.146$

$.0105 \pm 0.064$

USGS 12

$\begin{array}{ccccc}2.54 \pm 0.416 & 4.45 \pm 0.64 & 4.27 \pm 0.65 & 3.86 \pm 0.366 & 5 \\ 2.48 \pm 0.390 & 3.09 \pm 0.459 & 3.07 \pm 0.467 & 2.85 \pm 0.175 & 5 \\ -.305 \pm 0.148 & .084 \pm 0.128 & -.063 \pm 0.100 & -.078 \pm 0.069 & 5 \\ -.166 \pm 0.086 & .046 \pm 0.070 & -.038 \pm 0.060 & -.042 \pm 0.038 & 5\end{array}$

USGS 15

$\begin{array}{lllll}2.26 \pm 0.477 & 3.48 \pm 0.58 & 2.48 \pm 0.36 & 2.69 \pm 0.20 & 5 \\ 1.4( \pm \pm 0.306 & 2.44 \pm 0.4(07 & 1.70 \pm 0.236 & 1.78 \pm 0.153 & 5 \\ -.018 \pm(0.122 & 9.10 \pm 3 .(0) & .32(1) \pm 0.173 & 1.91 \pm 1.46 & 5 \\ -.010 \pm 0.068 & 7.28 \pm 2.62 & .1725 \pm 0.094 & 1.64 \pm 1.18 & 5\end{array}$


Table 15.-Statistical parameters for gross alpha-particle radioactivity expressed as uranium and thorium-230, by well-Continued

\begin{tabular}{|c|c|c|c|c|c|}
\hline \multirow[b]{2}{*}{ Constituent } & \multicolumn{4}{|c|}{ Statistical parameter } & \multirow[b]{2}{*}{$\begin{array}{r}\text { Sampl } \\
\text { size }\end{array}$} \\
\hline & Minimum & Maximum & Median & Mean & \\
\hline \multicolumn{6}{|c|}{ USGS 17} \\
\hline Uranium (dissolved) & $1.67 \pm 0.424$ & $3.43 \pm(1.56$ & $2.97 \pm 1) .56$ & $2.73 \pm(1.30$ & 5 \\
\hline Thorium-230 (dissolved) & $1 .(1) 4 \pm(1) .270$ & $2.34 \pm(1.391$ & $1.85 \pm(1) .352$ & $1.83 \pm 0.216$ & 5 \\
\hline Uranium (suspended) & $-(037 \pm() .174$ & $.178 \pm 0.158$ &.$-(13() \pm 1) .19()$ &.$(142 \pm(1) .(147$ & 5 \\
\hline Thorium-230 (suspended) &.$-(122 \pm(1) .101$ & $.096 \pm 0.088$ & $-.(1) 18 \pm() .115$ &.$(121 \pm(1) .(126$ & 5 \\
\hline \multicolumn{6}{|c|}{ USGS 97} \\
\hline Uranium (dissolved) & $2.64 \pm 1) .49 .3$ & $4.54 \pm(1.69$ & $3.86 \pm 0.601$ & 3.7()$\pm(1.25$ & 7 \\
\hline Thorium-230) (dissolved) & $1.82 \pm 1) .341$ & $3.08 \pm 11.476$ & $2.6(1 \pm() .421$ & $2.52 \pm 1) .1 .59$ & 7 \\
\hline Uranium (suspended) & $-.122 \pm 0.118$ & $.084 \pm(1.126$ & $-.018 \pm(1) .084$ &.$-(126 \pm 1) .028$ & 7 \\
\hline Thorium-230 (suspended) &.$-(166 \pm 0.064$ & $.(1) 46 \pm 0 .(1) 71$ &.$-(01() \pm(1) .(146$ &.$-(144 \pm(1) .(015$ & 7 \\
\hline \multicolumn{6}{|c|}{ USGS 98} \\
\hline Uranium (dissolved) & 2.6()$\pm() .51$ & $3.85 \pm 1) .65$ & 3.3() $.5 \pm() .41$ & $3.2(1 \pm 1) .2(1)$ & 6 \\
\hline Thorium-230 (dissolved) & $1.81 \pm() .359$ & $2.69 \pm 1.458$ & $2.21 \pm 1) .278$ & $2.18 \pm 1) .139$ & 6 \\
\hline Uranium (suspended) & $-.138 \pm 1) .168$ & $.037 \pm 0.232$ &.$-(168 \pm \pm(1) .115$ & $-.062 \pm 1) .(1) 30$ & 6 \\
\hline Thorium-230 (suspended) & $-.078 \pm 0.096$ &.$(120 \pm(0.129$ &.$(1395 \pm(1) .(167$ &.$-(135 \pm(1) .017$ & 6 \\
\hline \multicolumn{6}{|c|}{ USGS 99} \\
\hline Uranium (dissolved) & $2.87 \pm 10.54$ & $4.16 \pm 1) .62$ & $3.71 \pm(1) .43$ & $3.61 \pm 0.19$ & 6 \\
\hline Thorium-230 (dissolved) & $2 .(18 \pm 0.388$ & $2.87 \pm 10.438$ & $2.435 \pm 11.28$ & $2.46 \pm() .12$ & 6 \\
\hline Uranium (suspended) & $-.176 \pm 10.208$ & $.115 \pm 1) .182$ & $.0545 \pm(1) .135$ & $.(1) 26 \pm 0 .(1) 45$ & 6 \\
\hline Thorium-230 (suspended) &.$-(094 \pm(1) .112$ & $.(1) 62 \pm 0.106$ & $.(1) 325 \pm(0.082$ & $.(1) 15 \pm(1) .(1) 23$ & 6 \\
\hline \multicolumn{6}{|c|}{ USGS 102} \\
\hline Uranium (dissolved) & $3.32 \pm 10.058$ & $4.27 \pm 1) .64$ & $3.95 \pm(1.43$ & $3.88 \pm 0.16$ & 6 \\
\hline Thorium-230 (dissolved) & 2.4()$\pm 1) .416$ & $2.97 \pm(1.444$ & $2.735 \pm 1) .3(1) 1$ & $2.71 \pm 0.096$ & 6 \\
\hline Uranium (suspended) & $-.245 \pm(1) .183$ & $.0(09 \pm(1) .178$ & $-.1495 \pm(0.120$ & $-.144 \pm(1) .(14()$ & 6 \\
\hline Thorium-230 (suspended) & $-.144 \pm(1.110$ & $.0(05 \pm() .102$ & $-.082 \pm 0.066$ & $-(1) 81 \pm(1) .(123$ & 6 \\
\hline \multicolumn{6}{|c|}{ Water Supply INEL-1 } \\
\hline Uranium (dissolved) & $2.47 \pm(1.489$ & $4.76 \pm(1) .72$ & $3.72 \pm(1.42$ & $3.72 \pm 0.32$ & 6 \\
\hline Thorium-230 (dissolved) & $1.53 \pm(1.314$ & $2.98 \pm(1.474$ & $2.4 .5 \pm() .284$ & $2.42 \pm 1) .228$ & 6 \\
\hline Uranium (suspended) & $-.293 \pm(0.172$ & $.153 \pm(1.192$ & $-.162 \pm 0.126$ & $-.116 \pm 0.074$ & 6 \\
\hline Thorium-230 (suspended) & $-.168 \pm(1.103$ & $.093 \pm(1) .118$ & $-.088 \pm(1) .069$ & $-.06 .3 \pm(1) .042$ & 6 \\
\hline
\end{tabular}


Table 15.-Statistical parameters for gross alpha-particle radioactivity expressed as uranium and thorium-230, by welt - Continued

\begin{tabular}{|c|c|c|c|c|c|}
\hline \multirow[b]{2}{*}{ Constituent } & \multicolumn{4}{|c|}{ Statistical parameter } & \multirow[b]{2}{*}{$\begin{array}{c}\text { Sample } \\
\text { size }\end{array}$} \\
\hline & Minimum & Maximum & Median & Mean & \\
\hline \multicolumn{6}{|c|}{ All wells } \\
\hline Uranium (dissolved) & $1.67 \pm(1.424$ & $5.17 \pm 0.70$ & 3.7()$\pm 0.64$ & $3.65 \pm 1) .(19$ & 69 \\
\hline Thorium-230 (dissolved) & $1 .(1) 4 \pm(1.270$ & $3.72 \pm(1.50)$ & $2.55 \pm 1) .438$ & $2.5(1) \pm(1) .065$ & 69 \\
\hline Uranium (suspended) & $-.3(15 \pm() .148$ & $9.10 \pm 3.00$ &.$-(018 \pm(1) .084$ & $.141 \pm() .135$ & 69 \\
\hline Thorium-230 (suspended) & $-.168 \pm(0.1(1) 3$ & $7.28 \pm 2.62$ & $-.(1) 1 \pm(1) .(146$ & $.128 \pm(1) .110$ & 69 \\
\hline
\end{tabular}


Table 16.-Concentrations of gross beta-particle radioactivity in water, Naval Reactors Facility and vicinity

|Analyses were performed by the U.S. Geological Survey's National Water Quality Laboratory using a residue procedure. Analytical results and uncertainties--for example, 3.34 \pm (0.51--are in picocuries per liter. Analytical uncertainties are reported as 1s. Concentrations that exceed the reporting level of 3 times the is value are shown in boldface type. See figure 2 for location of wells. Sr-9)(Y) $\mathrm{Y}-9()$, strontium 9() in equilibrium with yttrium- 9() ; QAS, quality assurance sample (see Quality Assurance section in text for explanation). Raw field samples were processed in laboratory prior to analyses!

\begin{tabular}{|c|c|c|c|c|c|}
\hline \multirow[b]{2}{*}{$\begin{array}{l}\text { Well } \\
\text { identifier }\end{array}$} & \multirow{2}{*}{$\begin{array}{c}\text { Date } \\
\text { Sampled } \\
(\mathrm{m} / \mathrm{d} / \mathrm{y})\end{array}$} & \multicolumn{2}{|c|}{ Dissolved } & \multicolumn{2}{|c|}{ Suspended } \\
\hline & & $\begin{array}{c}\text { as } \\
S r-\varphi(1) / Y-\varphi()\end{array}$ & $\begin{array}{c}\text { as } \\
\text { cesium- } 137\end{array}$ & $\stackrel{a s}{S r-9() / Y-9()}$ & $\begin{array}{c}\text { as } \\
\text { cesium-137 }\end{array}$ \\
\hline QAS-8 & $11 / 2 / 90$ & $(1.249 \pm() .178$ & $0.26(1) \pm(0.187$ & $-(1) .(148 \pm(1) .238$ & -()$.(1) 49 \pm(1.244$ \\
\hline \multirow[t]{5}{*}{ NRF-1 } & $3 / 21 / 0(1)$ & $3.34 \pm 0.51$ & $4.37 \pm 10.67$ & $.193 \pm 0.228$ & $.242 \pm(1.286$ \\
\hline & $6 / 19 / 9()$ & $2.75 \pm 1) .484$ & $3.84 \pm 0.72$ & $.317 \pm 11.236$ & $.394 \pm(1.293$ \\
\hline & $8 / 7 / 9(1$ & $2.71 \pm 0.478$ & $3.78 \pm 0.73$ & $.33(1) \pm(1) .235$ & $.345 \pm(0.246$ \\
\hline & $10 / 2 / 9(1$ & $2.28 \pm 0.412$ & $3.15 \pm 0.62$ & $.199 \pm(1.253$ & $.211 \pm 0.268$ \\
\hline & $12 / 6 / 9()$ & $2.3(1) \pm(1.388$ & $3 .(1) \pm(0.51$ & $.187 \pm(1) .23()$ & $.193 \pm 0.238$ \\
\hline NRF-2 & $3 / 21 / 90$ & $3.48 \pm 1.51$ & $4.69 \pm 11.68$ & $.298 \pm 11.242$ & $.311 \pm(1.252$ \\
\hline \multirow[t]{5}{*}{ QAS-2 } & $3 / 21 / 90$ & $2.85 \pm 0.490$ & $3.81 \pm 0.66$ & $-.114 \pm 11.218$ & $-.144 \pm 10.276$ \\
\hline & $6 / 19 / 90$ & $3.35 \pm 11.76$ & $4.6(1 \pm+1) .84$ & $.178 \pm(1) .238$ & $.226 \pm 0.3(1) 2$ \\
\hline & $8 / 7 / 9()$ & $2.98 \pm 0.465$ & $3.91 \pm 0.61$ & $-.126 \pm(1.258$ & $-.134 \pm 0.273$ \\
\hline & $10 / 2 / 90$ & $2.8 .3 \pm 0.478$ & $3.75 \pm 0.64$ & $.6(1) 2 \pm(1) .252$ & $.63(1+1) .264$ \\
\hline & $12 / 5 / 90$ & $4.32 \pm 0.56$ & $5.76 \pm 0.75$ &.$(177 \pm(1) .242$ & $.08(1 \pm 0.250$ \\
\hline \multirow[t]{5}{*}{$N R F-3$} & $3 / 21 / 90$ & $3.04 \pm 0.54$ & $3.96 \pm 0.70$ & $.121 \pm 0.244$ & $.143 \pm(0.288$ \\
\hline & $6 / 19 / 90$ & $1.86 \pm 0.435$ & $2.56 \pm 0.63$ & -.23()$\pm 1) .246$ & $-.289 \pm(1) .310$ \\
\hline & $8 / 7 / 9()$ & $3.20 \pm 0.50$ & $4.31 \pm 0.68$ & .28()$\pm(1) .218$ & $.355 \pm(0.276$ \\
\hline & $10 / 2 / 90$ & $2.25 \pm(1.41) 8$ & $3 .(1) \pm 0.54$ & $.566 \pm(1) .260$ & .6()$(1) \pm 0.276$ \\
\hline & $12 / 6 / 9()$ & $2.49 \pm 0.415$ & $3.26 \pm 10.54$ & .59()$\pm(1) .24()$ & $.616 \pm() .250$ \\
\hline \multirow[t]{5}{*}{$N R F-4$} & $(6 / 19 / 90)$ & $3.12 \pm 0.54$ & $4.39 \pm 0.81$ & $.242 \pm 0.246$ & $.286 \pm 0.29()$ \\
\hline & $8 / 7 / 90$ & $2.09 \pm 11.414$ & $2.91 \pm 1.61$ & $.264 \pm 0.267$ & $.271 \pm() .274$ \\
\hline & $10 / 2 / 9()$ & $2.94 \pm 0.472$ & $3.84 \pm 10.62$ & $.06(1) \pm(0.246$ & $.062 \pm 0.254$ \\
\hline & $12 / 5 / 90$ & $3.21 \pm 0.477$ & $4.28 \pm 10.64$ & .13()$\pm 0.227$ & $.136 \pm 0.237$ \\
\hline & $2 / 7 / 91$ & $2.55 \pm 0.436$ & $3.37 \pm 1.58$ & $.174 \pm(1) .242$ & $.182 \pm(1.254$ \\
\hline QAS-12 & $2 / 7 / 91$ & $3.43 \pm 0.52$ & $4.56 \pm 0.68$ & $.617 \pm 0.274$ & $.638 \pm 0.284$ \\
\hline
\end{tabular}


Table 16.-Concentrations of gross beta-particle radioactivity in water, Naval Reactors Facility and vicinity-Continued

\begin{tabular}{|c|c|c|c|c|c|}
\hline \multirow[b]{2}{*}{$\begin{array}{l}\text { Well } \\
\text { identifier }\end{array}$} & \multirow{2}{*}{$\begin{array}{c}\text { Date } \\
\text { Sampled } \\
(\mathrm{m} / \mathrm{d} / \mathrm{y})\end{array}$} & \multicolumn{2}{|c|}{ Dissolved } & \multicolumn{2}{|c|}{ Suspended } \\
\hline & & $\begin{array}{c}\text { ai } \\
\operatorname{Sr}-\varphi() / Y-\varphi()\end{array}$ & $\begin{array}{c}\text { as } \\
\text { cesium- } 1.37\end{array}$ & $\begin{array}{c}\text { as } \\
\operatorname{Sr}-9() / Y-90\end{array}$ & $\begin{array}{c}\text { as } \\
\text { cesium-137 }\end{array}$ \\
\hline \multirow[t]{5}{*}{ USGS 12} & $8 / 6 / 90$ & $3.96 \pm(1) .56$ & $5.27 \pm 0.76$ & $-.(1) 16 \pm 1) .241$ & $-.019 \pm(0.284$ \\
\hline & $10 / 10 / 90$ & $2.51 \pm 0.4(06$ & $3.29 \pm 1.54$ & $.199 \pm(1) .253$ & $.211 \pm 0.268$ \\
\hline & $12 / 11 / 90$ & $3.5 .3 \pm 0.492$ & $4.71 \pm 0.66$ & $.349 \pm 1) .242$ & $.36(1 \pm \pm(1) .250$ \\
\hline & $2 / 7 / 91$ & $2.41 \pm 11.448$ & $3.21 \pm 0.60$ & $.423 \pm 0.262$ & $.438 \pm(0.270$ \\
\hline & $4 / 11 / 91$ & $2.46 \pm(1.410$ & $3.26 \pm 0.54$ & $.621 \pm(0.200)$ & $.639 \pm 0.205$ \\
\hline USGiS 15 & $8 / 6 / 90)$ & $2.95 \pm 10.498$ & $3.91 \pm 0.66$ & $1.68 \pm 0.3310$ & $2.12 \pm 0.414$ \\
\hline \multirow[t]{5}{*}{ QAS-6 } & $8 / 6 / 9()$ & $3.20 \pm 0.60$ & $4.38 \pm 0.88$ & $5.74 \pm 0.8(0)$ & $7.40 \pm 1.02$ \\
\hline & $10 / 9 / 90$ & $2.03 \pm 0.362$ & $2.73 \pm 0.485$ & $.158 \pm 0.248$ & $.163 \pm 0.256$ \\
\hline & $12 / 13 / 90$ & $1.52 \pm 0.296$ & $2.04 \pm 0.431$ & $.171 \pm() .244$ & $.176 \pm 0.250$ \\
\hline & $2 / 11 / 91$ & $1.42 \pm(1.282$ & $1.95 \pm 0.411$ & $.444 \pm 0.260$ & $.464 \pm 0.272$ \\
\hline & $4 / 12 / 91$ & $1.74 \pm 0.398$ & $2.36 \pm 0.463$ & $.361 \pm() .248$ & $.378 \pm(0.259$ \\
\hline \multirow[t]{5}{*}{ USGS 17} & $3 / 2(1 / 90)$ & 2.8()$\pm 0.41$ & $3.56 \pm 0.52$ &.$(057 \pm 0.222$ & $.059 \pm(0.232$ \\
\hline & $6 / 7 / 90)$ & $3.00 \pm 10.322$ & $4 .(07 \pm 0.52$ & .33()$\pm() .234$ & $.414 \pm 0.293$ \\
\hline & $8 / 2 / 90$ & $2.27 \pm 10.340$ & $2.99 \pm 0.50$ & $.216 \pm 1) .229$ & $.226 \pm(0.24()$ \\
\hline & $10 / 10 / 90$ & $2.00 \pm 0.324$ & $2.69 \pm 0.478$ & $.3(03 \pm 1) .257$ & $.313 \pm 0.266$ \\
\hline & $12 / 10 / 90$ & $2.25 \pm 0.333$ & $3.04 \pm 0.50$ & $.257 \pm(0.214$ & $.268 \pm 0.224$ \\
\hline \multirow[t]{2}{*}{ USGS 97} & $3 / 19 / 90$ & $3.15 \pm 0.52$ & $4.09 \pm 10.68$ & $.210 \pm(1) .244$ & $.266 \pm 0.308$ \\
\hline & $6 / 7 / 90$ & $2.68 \pm 0.492$ & $3.58 \pm 11.66$ & $.(1) 9(1) \pm 0.234$ & $.114 \pm 0.296$ \\
\hline \multirow[t]{4}{*}{ QAS-3 } & $6 / 7 / 90$ & $2.52 \pm 0.482$ & $3.37 \pm 0.64$ & $.252 \pm 1.218$ & $.314 \pm(0.270$ \\
\hline & $8 / 1 / 90$ & $2.79 \pm 1) .62$ & $3.83 \pm 0.68$ & $.156 \pm(1) .228$ & $.161 \pm 0.235$ \\
\hline & $10 / 4 / 90$ & $2.72 \pm 0.412$ & $3.59 \pm 0.54$ & $.285 \pm() .23()$ & $.298 \pm 0.240$ \\
\hline & $12 / 7 / 90$ & $3.49 \pm 10.482$ & $4.66 \pm 10.64$ & $.114 \pm(1) .2(1) 3$ & $.119 \pm 0.212$ \\
\hline QAS-10 & $12 / 7 / 90$ & $2.58 \pm 0.418$ & $3.43 \pm 0.56$ & .18()$\pm 0.234$ & $.191 \pm 0.248$ \\
\hline \multirow[t]{3}{*}{ USGS 98} & $3 / 19 / 90$ & $2.71 \pm 0.422$ & $3.58 \pm 0.56$ & $-.012 \pm(1.234$ & $-.014 \pm 0.277$ \\
\hline & $6 / 5 / 90$ & $3.64 \pm 0.465$ & $4.87 \pm 0.62$ & $.678 \pm(0.232$ & $.843 \pm() .288$ \\
\hline & $7 / 30 / 90)$ & $2.13 \pm 0.344$ & $2.92 \pm 0.52$ & $.452 \pm(1.249$ & $.464 \pm 0.256$ \\
\hline \multirow[t]{3}{*}{ QAS-5 } & $7 / 3() / 90$ & $2.75 \pm 0.393$ & $3.59 \pm 0.52$ & $.089 \pm(1.220$ & $.093 \pm(0.230$ \\
\hline & $10 / 3 / 90$ & $2.38 \pm 0.354$ & $3.3(1) \pm 1.54$ & .61()$\pm 0.277$ & $.63(1 \pm 0.286$ \\
\hline & $12 / 7 / 90$ & $2.06 \pm 10.466$ & $2.8 .3 \pm 0.51$ &.$(144 \pm 0.236$ & $.046 \pm(0.242$ \\
\hline
\end{tabular}


Table 16.-Concentrations of gross beta-particle radioactivity in water, Naval Reactors Facility and vicinity-Continued

\begin{tabular}{|c|c|c|c|c|c|}
\hline \multirow[b]{2}{*}{$\begin{array}{l}\text { Well } \\
\text { identifier }\end{array}$} & \multirow{2}{*}{$\begin{array}{c}\text { Date } \\
\text { Sampled } \\
(\mathrm{m} / \mathrm{d} / \mathrm{y})\end{array}$} & \multicolumn{2}{|c|}{ Dissolved } & \multicolumn{2}{|c|}{ Suspended } \\
\hline & & $\begin{array}{c}\text { as } \\
\mathrm{Sr}-\varphi() / \mathrm{Y}-\varphi()\end{array}$ & $\begin{array}{c}\text { as } \\
\text { cesium- } 1.37\end{array}$ & $\begin{array}{c}a s \\
\operatorname{Sr}-9() / Y-\varphi()\end{array}$ & $\begin{array}{c}\text { as } \\
\text { cesium-137 }\end{array}$ \\
\hline \multirow[t]{4}{*}{ USGS } & $3 / 2(1 / 90)$ & $3.42 \pm(1.52$ & $4.5(1) \pm 1) .68$ & $.158 \pm(1) .256$ & $.16 .3 \pm(0.264$ \\
\hline & $6 / 5 / 9()$ & $2.99 \pm 1.472$ & $3.9 .3 \pm(1.62$ &. $.33(1+1) .237$ & $.398 \pm(1.280$ \\
\hline & $8 / 1 / 9()$ & $1.7 .3 \pm 0.365$ & 2.4()$\pm(1) .54$ & $.181 \pm 1) .234$ & $.187 \pm 11.242$ \\
\hline & $10 / 3 / 90$ & $1.75 \pm 1 . .360$ & $2.3 .3 \pm 10.478$ & $-.16 .5 \pm 11.2 .54$ & $-.169 \pm(1.26()$ \\
\hline \multirow[t]{2}{*}{ QAS-7 } & $10 / 3 / 90$ & $3.28 \pm 0.470$ & $4.28 \pm 10.62$ &.$-(1860 \pm 1) .258$ & $-.088 \pm \pm 0.266$ \\
\hline & $12 / 1(1 / 90$ & $2.68 \pm 11.412$ & $3.5 .3 \pm 0.54$ &.$(174 \pm(1) .222$ &.$(177 \pm 0.231)$ \\
\hline \multirow[t]{3}{*}{ USGiS 112} & $8 / 1 / 9()$ & $2.6(1+10.429$ & $3.54 \pm 0.65$ &.$-(1.34 \pm(1) .232$ & $-.043 \pm 0.292$ \\
\hline & $1(1 / 4 / 9()$ & $3.44 \pm 11.458$ & $4.6 .3 \pm 0.62$ & $.578 \pm 1) .275$ & $.597 \pm 0.284$ \\
\hline & $12 / 10 / 9()$ & $2.06 \pm 0.430$ & $3.50 \pm 0.58$ & $.116 \pm(1.229$ & $.123 \pm 0.242$ \\
\hline \multirow[t]{3}{*}{ QAS-11 } & $12 / 10 / 9()$ & $3.14 \pm 11.466$ & $4.18 \pm 0.62$ &.$-(151 \pm 1) .229$ & $-.0152 \pm 0.236$ \\
\hline & $2 / 7 / 91$ & $2.37 \pm 0.4(16)$ & $3.11 \pm 10.5 .3$ & $.19 .3 \pm(1.242$ & $.199 \pm 0.24 x$ \\
\hline & $4 / 11 / 91$ & $2.98 \pm 10.460$ & $4.01 \pm 11.62$ &.$-(119 \pm 1) .236$ & $-.(1) 2(1) \pm() .244$ \\
\hline \multicolumn{6}{|c|}{ Water Supply } \\
\hline \multirow[t]{6}{*}{ INEL-1 } & $3 / 19 / 9()$ & $4.12 \pm 11.62$ & $5.51 \pm 11.84$ & $.193 \pm(1.228$ & $.242 \pm 0.280$ \\
\hline & $6 / 5 / 9()$ & $3.59 \pm 0.62$ & $4.8(1) \pm 0.82$ &.$-(126 \pm(1) .221$ & $-.033 \pm(1.280$ \\
\hline & $7 / 3() / 9()$ & $3.39 \pm 0.56$ & $4.52 \pm 0.76$ & $.0(1) 6 \pm 0.234$ & $.0(08 \pm 0.296$ \\
\hline & $10 / 3 / 9)$ & $3.32 \pm 0.53$ & $4.38 \pm 0.70$ & $.27(1) \pm(1.228$ & $.282 \pm(1.239$ \\
\hline & $12 / 7 / 90$ & $4.27 \pm(1.60$ & $5.72 \pm(1) .80$ &.$(142 \pm 1) .22()$ &.$(14.3 \pm 0.228$ \\
\hline & $12 / 7 / 90$ & $3.91 \pm 0.57$ & $5.22 \pm 0.76$ & $.357 \pm(1.246$ & $.378 \pm 0.260$ \\
\hline
\end{tabular}


Table 17. Statistical parameters for gross beta-particle radioactivity expressed as strontium90 in equilibrium with yttrium-90 and as cesium-137, by well

IUnits are picocuries per liter. Values are derived from table 16. See figure 2 for location of wells. Quality assurance replicates are included in the statistical parameters. Sr-90/Y-90, Strontium-9() in equilibrium with yttrium- 9()$)$

\begin{tabular}{|c|c|c|c|c|c|}
\hline \multirow[b]{2}{*}{ Constituent } & \multicolumn{4}{|c|}{ Statistical parameter } & \multirow[b]{2}{*}{$\begin{array}{l}\text { Sample } \\
\text { size }\end{array}$} \\
\hline & Minimum & Maximum & Median & Mean & \\
\hline \multicolumn{6}{|c|}{ NRF-1 } \\
\hline Sr-90/Y-90 (dissolved) & $2.28 \pm 0.412$ & $3.34 \pm() .51$ & $2.71 \pm() .478$ & $2.68 \pm 0.193$ & 5 \\
\hline Cesium-137 (dissolved) & $3.03 \pm 0.51$ & $4.37 \pm 0.67$ & $3.78 \pm 1) .73$ & $3.63 \pm 0.25$ & 5 \\
\hline Sr-90/Y-90 (suspended) & $.187 \pm() .230$ & $.33(10) .235$ & $.199 \pm() .253$ & $.245 \pm(0.032$ & 5 \\
\hline Cesium-137 (suspended) & $.193 \pm 0.238$ & $.394 \pm() .293$ & $.242 \pm 0.286$ & $.277 \pm 0.039$ & 5 \\
\hline \multicolumn{6}{|c|}{ NRF-2 } \\
\hline Sr-9()/Y-9() (dissolved) & $2.83 \pm(1) .478$ & $4.32 \pm(1.56$ & $3.165 \pm() .45$ & 3.3()$\pm 0.23$ & 6 \\
\hline Cesium-137 (dissolved) & $3.75 \pm 0.64$ & $5.76 \pm 0.75$ & $4.255 \pm() .52$ & $4.42 \pm 1) .32$ & 6 \\
\hline Sr-90/Y-90 (suspended) & $-.126 \pm() .258$ &.$(6() 2 \pm 1) .252$ & $.1275 \pm() .17()$ & $.152 \pm 0.112$ & 6 \\
\hline Cesium-137 (suspended) & $-.144 \pm 1) .276$ & .63()$\pm 1) .264$ & $.153 \pm(1) .196$ & $.162 \pm() .120$ & 6 \\
\hline \multicolumn{6}{|c|}{ NRF-3 } \\
\hline Sr-90/Y-90 (dissolved) & $1.86 \pm 0.435$ & 3.2()$\pm(0.50$ & $2.49 \pm(0.415$ & $2.57 \pm 1) .248$ & 5 \\
\hline Cesium-137 (dissolved) & $2.56 \pm 0.63$ & $4.31 \pm 0.68$ & $3.26 \pm(1) .54$ & $3.42 \pm 1) .32$ & 5 \\
\hline Sr-90/Y-90 (suspended) & -.23()$\pm() .246$ & .59()$\pm() .240$ & .28()$\pm() .218$ & $.265 \pm() .152$ & 5 \\
\hline Cesium-137 (suspended) & $-.289 \pm 0.310$ & $.616 \pm 0.250$ & $.355 \pm 0.276$ & $.285 \pm 0.168$ & 5 \\
\hline \multicolumn{6}{|c|}{ NRF-4 } \\
\hline Sr-90/Y-90 (dissolved) & $2 .(1) 9 \pm 1) .414$ & $3.43 \pm(1) .52$ & $3 .(1) 3 \pm(1) .36$ & $2.89 \pm(1) .20$ & 6 \\
\hline Cesium-137 (dissolved) & $2.91 \pm(0.61$ & $4.56 \pm(1) .68$ & $4.06 \pm(1) .45$ & $3.89 \pm(1.26$ & 6 \\
\hline Sr-90/Y-90 (suspendiad) &.$(160() \pm 0.246$ & $.617 \pm(0.274$ & $.2(18 \pm() .173$ & $.248 \pm(1.080$ & 6 \\
\hline Cesium-137 (suspended) & $.062 \pm 0.254$ & $.638 \pm 0.284$ & $.2265 \pm(1) .187$ & $.262 \pm 0.083$ & 6 \\
\hline \multicolumn{6}{|c|}{ USGS 12} \\
\hline Sr-90/Y-90) (dissolved) & $2.41 \pm 0.448$ & $3.96 \pm 0.56$ & $2.51 \pm(1) .406$ & $2.97 \pm 0.32$ & 5 \\
\hline Cesium-137 (dissolved) & $3.21 \pm 0.60$ & $5.27 \pm 0.76$ & $3.29 \pm(0.54$ & $3.95 \pm 0.43$ & 5 \\
\hline Sr-90/Y-90 (suspended) &.$-(16 \pm(1) .241$ & $.621 \pm(0.200$ & $.349 \pm() .242$ & $.315 \pm(1) .107$ & 5 \\
\hline Cesium-137 (suspended) & $-.019 \pm(1) .284$ & $.639 \pm(0.205$ & .36()$\pm(1.250$ & $.326 \pm(0.110$ & 5 \\
\hline \multicolumn{6}{|c|}{ USGS 15} \\
\hline Sr-90/Y-90 (dissolved) & $1.42 \pm 0.282$ & $3.20 \pm(0.60$ & $1.885 \pm(1.269$ & $2.14 \pm 0.308$ & 6 \\
\hline Cesium-137 (dissolved) & $1.95 \pm(0.411$ & $4.38 \pm 0.88$ & $2.545 \pm(1.335$ & 2.9()$\pm(1) .415$ & 6 \\
\hline $\mathrm{Sr}-90 / \mathrm{Y}-90$ (suspended) & $.158 \pm 0.248$ & $5.74 \pm() .80$ & $.4(125 \pm(1) .180$ & $1.43 \pm 0.894$ & 6 \\
\hline Cesium-137 (suspended) & $.163 \pm 0.256$ & 7.4()$\pm 1 .(1) 2$ & $.421 \pm(1.188$ & $1.78 \pm 1.16$ & 6 \\
\hline
\end{tabular}


Table 17. - Statistical parameters for gross beta-particle radioactivity expressed as strontium90 in equilibrium with yttrium-90 and as cesium-137, by welt-Continued

\begin{tabular}{|c|c|c|c|c|c|}
\hline \multirow[b]{2}{*}{ Constituent } & \multicolumn{4}{|c|}{ Statistical parameter } & \multirow{2}{*}{$\begin{array}{l}\text { Sample } \\
\text { size }\end{array}$} \\
\hline & Minimum & Maximum & Median & Mean & \\
\hline \multicolumn{6}{|c|}{ USGS 17} \\
\hline Sr-9()/Y-9() (dissolved) & $2 .(1) \pm(1) .324$ & $3 .(1) \pm() .322$ & $2.27 \pm() .34()$ & $2.46 \pm(1) .187$ & 5 \\
\hline Cesium-137 (dissolved) & $2.69 \pm(0.478$ & $4.07 \pm(1) .52$ & $3 .(1) 4 \pm() .50$ & $3.27 \pm 0.24$ & 5 \\
\hline Sr-y()/Y-y() (suspended) &.$(0.57 \pm 0.222$ & .33()$\pm(0.234$ & $.257 \pm() .214$ & $.233 \pm(0.0) 48$ & 5 \\
\hline Cesium-1.37 (suspended) &.$(0.59 \pm(1) .232$ & $.414 \pm(1.293$ & $.268 \pm 1) .224$ & $.256 \pm 0.058$ & 5 \\
\hline \multicolumn{6}{|c|}{ USGS 97} \\
\hline $\mathrm{Sr}-9() / \mathrm{Y}-()()$ (dissolved) & $2.52 \pm 1) .4 \times 2$ & $3.49 \pm 0.482$ & $2.72 \pm(1.412$ & $2.85 \pm(1) .132$ & 7 \\
\hline Cesium-1.37 (dissolved) & $3.37 \pm(1) .64$ & $4.66 \pm(1) .64$ & $3.59 \pm() .54$ & $3.79 \pm() .17$ & 7 \\
\hline $\mathrm{Sr}-(9) / \mathrm{Y}-9()$ (suspended) & $.(1) 9(1) \pm 0.234$ & $.28 .5 \pm() .230$ & $.18(1 \pm 1) .234$ & $.184 \pm 1) .027$ & 7 \\
\hline Cesium-137 (suspended) & $.114 \pm 0.296$ & $.314 \pm(1.27()$ & $.191 \pm(1.248$ & $.2(19 \pm \pm(1.032$ & 7 \\
\hline \multicolumn{6}{|c|}{ USGS 98} \\
\hline Sr-y()/Y-y() (dissolved) & $2.1)( \pm \pm 1.466$ & $3.64 \pm 0.46 .5$ & $2.545 \pm 1.27 .5$ & $2.61 \pm 10.236$ & 6 \\
\hline Cesium-137 (dissolved) & $2.83 \pm(1.51$ & $4.87 \pm 0.62$ & $3.44 \pm 1) .39$ & $3.52 \pm() .30$ & 6 \\
\hline Sr-9()/Y-y() (suspended) & $-.(1) 12 \pm(1.234$ & $.678 \pm 1) .232$ & $.27(0.5 \pm() .166$ & $.31(1+0) .125$ & 6 \\
\hline Cesium-137 (suspended) &.$-(014 \pm(1.277$ & $.843 \pm(0.288$ & $.2785 \pm 0.172$ & $.344 \pm(144$ & 6 \\
\hline \multicolumn{6}{|c|}{ USGS 99 } \\
\hline $\mathrm{Sr}-9() / \mathrm{Y}-9()$ (dissolved) & $1.73 \pm(1.36 .5$ & $3.42 \pm(1.52$ & $2.83 .5 \pm(1) .31 .3$ & $2.64 \pm(0.3() 3$ & 6 \\
\hline Cesium-137 (dissolved) & $2.33 \pm 1.478$ & 4.5()$\pm(1) .68$ & $3.73 \pm 1) .41$ & 3.5()$\pm 1) .38$ & 6 \\
\hline $\mathrm{Sr}-9() / \mathrm{Y}-9()$ (suspended) & $-.16 .5 \pm 1) .2 .54$ & $.336 \pm 1) .237$ & $.116 \pm 0.169$ & $.(183 \pm 1) .(175$ & 6 \\
\hline Cesium-137 (suspended) & $-.169 \pm(1.260)$ & $.398 \pm(1.280$ & .12()$\pm() .175$ &.$(095 \pm() .083$ & 6 \\
\hline \multicolumn{6}{|c|}{ USGS 102} \\
\hline $\mathrm{Sr}-9() / \mathrm{Y}-9()($ dissolved) & $2.37 \pm(1.4() 6$ & $3.44 \pm 1) .458$ & $2.82 \pm(1.31 .5$ & $2.86 \pm 1) .161$ & 6 \\
\hline Cesium-137 (dissolved) & $3.11 \pm 10.53$ & $4.63 \pm(1) .62$ & $3.78 .5 \pm(1.42$ & $3.84 \pm() .22$ & 6 \\
\hline $\mathrm{Sr}-9() / \mathrm{Y}-90$ (suspended) & $-.051 \pm() .229$ & $.578 \pm(1.275$ &.$(1485 \pm 1) .164$ & $.130 \pm(1.098$ & 6 \\
\hline Cesium-137 (suspended) & $-.(1) 52 \pm 1) .236$ & $.597 \pm 1) .284$ &.$(0.51 .5 \pm() .172$ & $.134 \pm() .101$ & 6 \\
\hline \multicolumn{6}{|c|}{ Water Supply INEL-1 } \\
\hline Sr-9()/Y-9() (dissolved) & $3.32 \pm(1.53$ & $4.27 \pm() .6()$ & $3.75 \pm(1.42$ & $3.77 \pm 1.16$ & 6 \\
\hline Cesium-137 (dissolved) & $4.38 \pm(1.70$ & $5.72 \pm(1.80$ & $5 .(1) 1 \pm 0.56$ & $5 .(12 \pm 0.22$ & 6 \\
\hline $\mathrm{Sr}-9() / \mathrm{Y}-9()$ (suspended) & $-.(1) 26 \pm(1) .221$ & $.357 \pm 0.246$ & $.1175 \pm(1.158$ & .14()$\pm(0.064$ & 6 \\
\hline Cesium-137 (suspended) & $-(03.3 \pm(0.280$ & $.378 \pm() .260$ & $.1425 \pm(0.183$ & $.153 \pm(1) .(169$ & 6 \\
\hline
\end{tabular}


Table 17. Statistical parameters for gross beta-particle radioactivity expressed as strontium90 in equilibrium with yttrium-90 and as cesium-137, by well-Continued

\begin{tabular}{|c|c|c|c|c|c|}
\hline \multirow[b]{2}{*}{ Constituent } & \multicolumn{4}{|c|}{ Statistical parameter } & \multirow[b]{2}{*}{$\begin{array}{c}\text { Sample } \\
\text { size }\end{array}$} \\
\hline & Minimum & Maximum & Median & Mean & \\
\hline \multicolumn{6}{|c|}{ All wells } \\
\hline Sr-90/Y-90 (dissolved) & $1.42 \pm 0.282$ & $4.32 \pm 0.56$ & $2.79 \pm 0.62$ & $2.82 \pm 0.08$ & 69 \\
\hline Cesium-137 (dissolved) & $1.95 \pm 0.411$ & $5.76 \pm 0.75$ & $3.78 \pm 0.73$ & $3.77 \pm 0.10$ & 69 \\
\hline Sr-90/Y-90 (suspended) & $-.230 \pm 0.246$ & $5.74 \pm(0.80$ & $.193 \pm 0.228$ & $.312 \pm 0.086$ & 69 \\
\hline C'esium-137 (suspended) & $-.289 \pm 0.310$ & $7.40 \pm 1.02$ & $.211 \pm 0.268$ & $.359 \pm 0.118$ & 69 \\
\hline
\end{tabular}


Table 18.-Concentrations of radium-226 and radium-228 in water, Naval Reactors Facility and vicinity

A Analyses were performed by the U.S. Geological Survey's National Water Quality Laboratory using radon emanation for radium-226 and separation and beta counting for radium-228.

Analytical results are in picocuries per liter. Analytical uncertainties are reported as $1 \mathbf{s}$. Concentrations that exceed the reporting level of 3 times the $1 \mathrm{~s}$ value are shown in boldface type. See figure 2 for location of wells. QAS, quality assurance sample (see Quality Assurance section in text for explanation); NA, analyses not performed by laboratory. Raw field samples were processed in laboratory prior to analyses]

\begin{tabular}{|c|c|c|c|}
\hline $\begin{array}{l}\text { Well } \\
\text { identifier }\end{array}$ & $\begin{array}{l}\text { Date sampled } \\
\qquad(\mathrm{m} / \mathrm{dl} / \mathrm{y})\end{array}$ & Radium-226 & Radium-228 \\
\hline QAS-8 & $11 / 2 / 9()$ & $0.075 \pm 0.008$ & $.472 \pm 0.195$ \\
\hline NRF-1 & $\begin{array}{l}3 / 21 / 90 \\
6 / 19 / 90 \\
8 / 7 / 90 \\
10 / 2 / 90 \\
12 / 6 / 90\end{array}$ & $\begin{array}{l}.026 \pm 0.004 \\
.102 \pm 0.0(09 \\
.067 \pm 0.0(1) 9 \\
.135 \pm 0.011 \\
.082 \pm 0.008\end{array}$ & $\begin{array}{l}.152 \pm 0.14() \\
.157 \pm(0.020 \\
.142 \pm(0.222 \\
.473 \pm(0.204 \\
.134 \pm 0.116\end{array}$ \\
\hline $\begin{array}{l}\text { NRF-2 } \\
\text { QAS-2 }\end{array}$ & $\begin{array}{l}3 / 21 / 90 \\
3 / 21 / 90 \\
6 / 19 / 90 \\
8 / 7 / 90 \\
10 / 2 / 90 \\
12 / 5 / 90\end{array}$ & $\begin{array}{l}\text { NA } \\
-.(1) 2 \pm(1) .(0) 4 \\
.067 \pm 0.007 \\
.089 \pm 0.010 \\
.065 \pm 0.007 \\
.068 \pm 0.010\end{array}$ & $\begin{array}{l}.045 \pm 0.126 \\
.144 \pm(0.164 \\
.144 \pm 0.181 \\
.193 \pm 0.230 \\
.147 \pm 0.179 \\
.264 \pm 0.186\end{array}$ \\
\hline NRF-3 & $\begin{array}{l}3 / 21 / 90 \\
6 / 19 / 90 \\
8 / 7 / 90 \\
10 / 2 / 90 \\
12 / 6 / 90\end{array}$ & $\begin{array}{c}.0(187 \pm(1) .0(1) 38 \\
.06 .3 \pm 0.0108 \\
.145 \pm 0.013 \\
.083 \pm 0.010 \\
.081 \pm 0.009\end{array}$ & $\begin{array}{l}.113 \pm 0.123 \\
.126 \pm 0.32() \\
.087 \pm 0.233 \\
.(091 \pm 0.187 \\
.018 \pm 0.110\end{array}$ \\
\hline QAS-12 & $\begin{array}{l}6 / 19 / 90 \\
8 / 7 / 90 \\
10 / 2 / 90 \\
12 / 5 / 90 \\
2 / 7 / 91 \\
2 / 7 / 91\end{array}$ & $\begin{array}{l}.106 \pm 0.009 \\
.019 \pm 0.005 \\
.975 \pm 0.008 \\
.112 \pm 0.012 \\
.035 \pm 0.007 \\
.023 \pm 0.0114\end{array}$ & $\begin{array}{r}-.133 \pm(1.200 \\
.02() \pm(0.217 \\
.17() \pm 0.178 \\
.232 \pm 0.128 \\
.37(1 \pm(0.160 \\
.215 \pm 0.140\end{array}$ \\
\hline
\end{tabular}


Table 18.-Concentrations of radium-226 and radium-228 in water, Naval Reactors Facility and vicinity-Continued

\begin{tabular}{|c|c|c|c|}
\hline $\begin{array}{l}\text { Well } \\
\text { identifier }\end{array}$ & $\begin{array}{l}\text { Date sampled } \\
\qquad(\mathrm{m} / \mathrm{d} / \mathrm{y})\end{array}$ & Radium-226 & Radium-228 \\
\hline USGS 12 & $\begin{array}{l}8 / 6 / 90 \\
10 / 10 / 90 \\
12 / 11 / 90 \\
2 / 7 / 91 \\
4 / 11 / 91\end{array}$ & $\begin{array}{l}.050 \pm 0.008 \\
.009 \pm(-0.007 \\
.129 \pm 0.011 \\
.024 \pm 0.004 \\
.018 \pm 0.006\end{array}$ & $\begin{array}{l}.307 \pm 0.390 \\
.152 \pm 0.138 \\
.524 \pm 0.156 \\
.05() \pm 0.113 \\
.079 \pm 0.108\end{array}$ \\
\hline $\begin{array}{l}\text { USGS } 15 \\
\text { QAS-6 }\end{array}$ & $\begin{array}{l}8 / 6 / 90 \\
8 / 6 / 90 \\
10 / 9 / 90 \\
12 / 13 / 90 \\
2 / 11 / 91 \\
4 / 12 / 91\end{array}$ & $\begin{array}{l}.102 \pm 0.009 \\
.048 \pm 0.007 \\
.087 \pm 0.009 \\
.080 \pm 0.009 \\
.017 \pm 0.004 \\
.022 \pm 0.004\end{array}$ & $\begin{array}{l}.058 \pm 0.378 \\
.539 \pm 0.448 \\
.299 \pm 0.154 \\
.449 \pm 0.148 \\
.094 \pm 0.122 \\
.199 \pm 0.136\end{array}$ \\
\hline USGS 17 & $\begin{array}{l}3 / 20 / 90 \\
6 / 7 / 90 \\
8 / 2 / 90 \\
10 / 10 / 90 \\
12 / 10 / 90\end{array}$ & $\begin{array}{l}.037 \pm 0.004 \\
.079 \pm 0.008 \\
.05(0 \pm 0.007 \\
.093 \pm 0.009 \\
.101 \pm 0.009\end{array}$ & $\begin{array}{r}.304 \pm 0.166 \\
-.049 \pm 0.167 \\
.275 \pm 0.431 \\
.132 \pm 0.176 \\
.352 \pm 0.132\end{array}$ \\
\hline USGS 97 & $\begin{array}{l}3 / 19 / 90 \\
6 / 7 / 90\end{array}$ & $\begin{array}{l}.018 \pm 0.004 \\
.097 \pm 0.009\end{array}$ & $\begin{array}{l}.075 \pm 0.149 \\
.111 \pm 0.183\end{array}$ \\
\hline QAS-10 & $\begin{array}{l}6 / 7 / 90 \\
8 / 1 / 90 \\
10 / 4 / 90 \\
12 / 7 / 90 \\
12 / 7 / 90\end{array}$ & $\begin{array}{l}.088 \pm 0.009 \\
.054 \pm 0.008 \\
.149 \pm 0.013 \\
.086 \pm 0.1008 \\
.094 \pm 0.010\end{array}$ & $\begin{array}{l}.393 \pm 0.224 \\
.324 \pm 0.411 \\
. \mathbf{4 8 6} \pm 0.154 \\
.224 \pm 0.130 \\
.096 \pm 0.118\end{array}$ \\
\hline USGS 98 & $\begin{array}{l}3 / 19 / 90 \\
6 / 5 / 90 \\
7 / 30 / 90 \\
7 / 30 / 90 \\
10 / 3 / 90 \\
12 / 7 / 90\end{array}$ & $\begin{array}{l}.022 \pm 0.004 \\
.051 \pm 0.006 \\
.093 \pm 0.010 \\
.054 \pm 0.008 \\
.086 \pm 0.009 \\
.071 \pm 0.008\end{array}$ & $\begin{array}{r}.154 \pm 0.142 \\
.372 \pm 0.383 \\
-.07(0 \pm 0.237 \\
.26(0 \pm 0.211 \\
.372 \pm 0.231 \\
.154 \pm 0.134\end{array}$ \\
\hline
\end{tabular}


Table 18.-Concentrations of radium-226 and radium-228 in water, Naval Reactors Facility and vicinity-Continued

\begin{tabular}{|c|c|c|c|}
\hline $\begin{array}{l}\text { Well } \\
\text { identifier }\end{array}$ & $\begin{array}{l}\text { Date sampled } \\
(\mathrm{m} / \mathrm{d} / \mathrm{y})\end{array}$ & Radium-226 & Radium-228 \\
\hline \multirow[t]{4}{*}{ USGS 99} & $3 / 20 / 90$ & $.016 \pm 0.005$ & $.141 \pm 0.124$ \\
\hline & $6 / 5 / 90$ & $.064 \pm 0.007$ & $.109 \pm 0.396$ \\
\hline & $8 / 1 / 90$ & $.096 \pm 0.009$ & $.034 \pm 0.186$ \\
\hline & $10 / 3 / 90$ & $.011 \pm 0.008$ & $.442 \pm 0.173$ \\
\hline \multirow[t]{2}{*}{ QAS-7 } & $10 / 3 / 90$ & $.109 \pm 0.010$ & $.449 \pm 0.207$ \\
\hline & $12 / 10 / 90$ & $.087 \pm 0.008$ & $.328 \pm(0.141$ \\
\hline \multirow[t]{3}{*}{ USGS 102} & $8 / 1 / 90$ & $.131 \pm 0.011$ & $.079 \pm 0.181$ \\
\hline & $10 / 4 / 90$ & $.142 \pm 0.012$ & $.070 \pm(0.110$ \\
\hline & $12 / 10 / 90$ & $.087 \pm 0.009$ & $.222 \pm 0.126$ \\
\hline \multirow[t]{3}{*}{ QAS-11 } & $12 / 10 / 90$ & $.116 \pm 0.011$ & $.256 \pm 0.122$ \\
\hline & $2 / 7 / 91$ & $.028 \pm 0.004$ & $.137 \pm 0.125$ \\
\hline & $4 / 11 / 91$ & $.015 \pm 0.006$ & $.231 \pm 0.127$ \\
\hline \multicolumn{4}{|c|}{ Water Supply } \\
\hline \multirow[t]{5}{*}{ INEL-1 } & $3 / 19 / 90$ & $.044 \pm 0.006$ & $.545 \pm 0.176$ \\
\hline & $6 / 5 / 90$ & $.079 \pm 0.008$ & $.140 \pm 0.172$ \\
\hline & $7 / 30 / 90$ & $.072 \pm 0.010$ & $.305 \pm 0.305$ \\
\hline & $10 / 3 / 90$ & $.115 \pm 0.011$ & $.433 \pm 0.228$ \\
\hline & $12 / 7 / 90$ & $.089 \pm 0.010$ & $.256 \pm 0.132$ \\
\hline QAS-9 & $12 / 7 / 9()$ & $.152 \pm 0.013$ & $.437 \pm 0.140$ \\
\hline
\end{tabular}


Table 19.-Statistical parameters for radium-226 and radium-228, by well

[Units are picocuries per liter. Values are derived from table 18. See figure 2 for location of wells. Quality assurance replicates are included in the statistical parameters]

\begin{tabular}{|c|c|c|c|c|c|}
\hline \multirow[b]{2}{*}{ Constituent } & \multicolumn{4}{|c|}{ Statistical parameter } & \multirow[b]{2}{*}{$\begin{array}{c}\text { Sample } \\
\text { size }\end{array}$} \\
\hline & Minimum & Maximum & Median & Mean & \\
\hline \multicolumn{6}{|c|}{ NRF-1 } \\
\hline Radium-226 & $0.026 \pm 0.004$ & $0.135 \pm 0.011$ & $0.082 \pm 0.008$ & $0.082 \pm 0.018$ & 5 \\
\hline Radium-228 & $.134 \pm 0.116$ & $.473 \pm 0.204$ & $.152 \pm 0.140$ & $.212 \pm 0.065$ & 5 \\
\hline \multicolumn{6}{|c|}{ NRF -2} \\
\hline Radium-226 & $-.002 \pm 0.004$ & $.089 \pm 0.010$ & $.067 \pm 0.007$ & $.057 \pm 0.015$ & 5 \\
\hline Radium-228 & $.045 \pm 0.126$ & $.264 \pm 0.186$ & $.1455 \pm 0.103$ & $.156 \pm 0.029$ & 6 \\
\hline \multicolumn{6}{|c|}{ NRF -3} \\
\hline Radium-226 & $.0087 \pm 0.0038$ & $.145 \pm 0.013$ & $.081 \pm 0.009$ & $.076 \pm 0.022$ & 5 \\
\hline Radium-228 & $.018 \pm 0.110$ & $.126 \pm 0.320$ & $.091 \pm 0.187$ & $.087 \pm 0.019$ & 5 \\
\hline \multicolumn{6}{|c|}{ NRF-4 } \\
\hline Radium-226 & $.019 \pm 0.005$ & $.975 \pm 0.008$ & $.0705 \pm 0.056$ & $.212 \pm 0.154$ & 6 \\
\hline Radium-228 & $-.133 \pm 0.200$ & $.370 \pm 0.160$ & $.1925 \pm 0.137$ & $.146 \pm 0.072$ & 6 \\
\hline \multicolumn{6}{|c|}{ USGS 12} \\
\hline Radium-226 & $.009 \pm 0.007$ & $.129 \pm 0.011$ & $.024 \pm 0.004$ & $.046 \pm 0.022$ & 5 \\
\hline Radium-228 & $.050 \pm 0.113$ & $.524 \pm 0.156$ & $.152 \pm 0.138$ & $.222 \pm 0.088$ & 5 \\
\hline \multicolumn{6}{|c|}{ USGS 15} \\
\hline Radium-226 & $.017 \pm 0.004$ & $.102 \pm 0.009$ & $.064 \pm 0.047$ & $.059 \pm 0.014$ & 6 \\
\hline Radium-228 & $.058 \pm 0.378$ & $.539 \pm 0.448$ & $.249 \pm 0.180$ & $.273 \pm 0.079$ & 6 \\
\hline \multicolumn{6}{|c|}{ USGS 17} \\
\hline Radium-226 & $.037 \pm 0.004$ & $.101 \pm 0.009$ & $.079 \pm 0.008$ & $.072 \pm 0.012$ & 5 \\
\hline Radium-228 & $-.049 \pm 0.167$ & $.352 \pm 0.132$ & $.275 \pm 0.431$ & $.203 \pm 0.073$ & 5 \\
\hline \multicolumn{6}{|c|}{ USGS 97} \\
\hline Radium-226 & $.018 \pm 0.004$ & $.149 \pm 0.013$ & $.088 \pm 0.009$ & $.084 \pm 0.015$ & 7 \\
\hline Radium-228 & $.075 \pm 0.149$ & $.486 \pm 0.154$ & $.224 \pm 0.130$ & $.244 \pm 0.061$ & 7 \\
\hline \multicolumn{6}{|c|}{ USGS 98} \\
\hline Radium-226 & $.022 \pm 0.004$ & $.093 \pm 0.010$ & $.0625 \pm 0.045$ & $.063 \pm 0.011$ & 6 \\
\hline Radium-228 & $-.070 \pm 0.237$ & $.372 \pm 0.231$ & $.207 \pm 0.151$ & $.207 \pm 0.068$ & 6 \\
\hline
\end{tabular}


Table 19.-Statistical parameters for radium-226 and radium-228, by well - Continued

\begin{tabular}{|c|c|c|c|c|c|}
\hline \multirow[b]{2}{*}{ Constituent } & \multicolumn{4}{|c|}{ Statistical parameter } & \multirow[b]{2}{*}{$\begin{array}{c}\text { Sample } \\
\text { size }\end{array}$} \\
\hline & Minimum & Maximum & Median & Mean & \\
\hline \multicolumn{6}{|c|}{ USGS 99 } \\
\hline Radium-226 & $.011 \pm 0.008$ & $.109 \pm 0.010$ & $.0755 \pm 0.054$ & $.064 \pm 0.017$ & 6 \\
\hline Radium-228 & $.034 \pm 0.186$ & $.449 \pm 0.2(07$ & $.2345 \pm 0.179$ & $.250 \pm 0.073$ & 6 \\
\hline \multicolumn{6}{|c|}{ USGS 102} \\
\hline Radium-226 & $.015 \pm 0.006$ & $.142 \pm 1) .012$ & $.1015 \pm 0.072$ & $.086 \pm 0.022$ & 6 \\
\hline Radium-228 & $.070 \pm 0.110$ & $.256 \pm() .122$ & $.1795 \pm 0.130$ & $.166 \pm 0.033$ & 6 \\
\hline \multicolumn{6}{|c|}{ Water Supply INEL-1 } \\
\hline Radium-226 & $.044 \pm 0.006$ & $.152 \pm 0.013$ & $.084 \pm 0.060$ & $.092 \pm 0.015$ & 6 \\
\hline Radium-228 & .14()$\pm 0.172$ & $.545 \pm 0.176$ & $.369 \pm 0.265$ & $.353 \pm 0.060$ & 6 \\
\hline \multicolumn{6}{|c|}{ All wells } \\
\hline Radium-226 & -.0() $2 \pm 0.004$ & $.975 \pm 0.008$ & $.079 \pm 0.008$ & $.084 \pm 0.015$ & 68 \\
\hline Radium-228 & $-.133 \pm 0.200$ & $.545 \pm(0.176$ & $.157 \pm 0.020$ & $.212 \pm(0.019$ & 69 \\
\hline
\end{tabular}


Table 20.-Purgeable organic compounds for which water samples were analyzed [Analyses were performed by the U.S. Geological Survey's National Water Quality Laboratory using an analytical method that conforms to U.S. Environmental Protection Agency method 524.2. Reporting level for all compounds is 0.2 micrograms per liter (Pritt and Jones, 1989)]

Compound Compound

Benzene

Bromoform

Carbon tetrachloride

Chlorobenzene

Chloroethane

2-Chloroethyl vinyl ether

Chloroform

Chloromethane

Dibromochloromethane

Dichlorobromomethane

1,2-Dichlorobenzene

1,3-Dichlorobenzene

1,4-Dichlorobenzene

Dichlorodifluoromethane

1,2-Dibromoethane

1,1-Dichloroethane

1,2-Dichloroethane

1,1-Dichloroethylene

1,2-trans-Dichloroethylene

1,2-Dichlorepropane
Cis-1,3-Dichloropropene

Trans-1,3-Dichloropropene

1,3-Dichloropropene

Ethylbenzene

Methyl bromide

Styrene

Methylene chloride

1,1,2,2-Tetrachloroethane

Tetrachloroethylene

Toluene

Trichlorofluoromethane

1,1,1-Trichloroethane

1,1,2-Trichloroethane

Trichloroethylene

Vinyl chloride

Xylenes, mixed 
Table 21.-Concentrations of selected total recoverable trace elements in water from the Central Facilities Area water supply and the Naval Reactors Facility water supply

[Analyses were performed by the U.S. Geological Survey's National Water Quality Laboratory. Analytical results are in micrograms per liter. Water samples were collected on March 18, 1991 for comparison. See figure 1 for location of facilities. <, concentration is less than indicated reporting level]

Trace elements

Central Facilities Area water supply
Naval Reactors Facility water supply

Arsenic

Barium

Cadmium

Chromium

Copper

Iron

Lead

Manganese

Nickel

Selenium

Silver

Zinc

1
$<10(0$
$<1$
11
4
1,300
1
20
2
3
$<1$
10

1
$<100$
8
11
3
550
3
20
1
6
$<1$
20



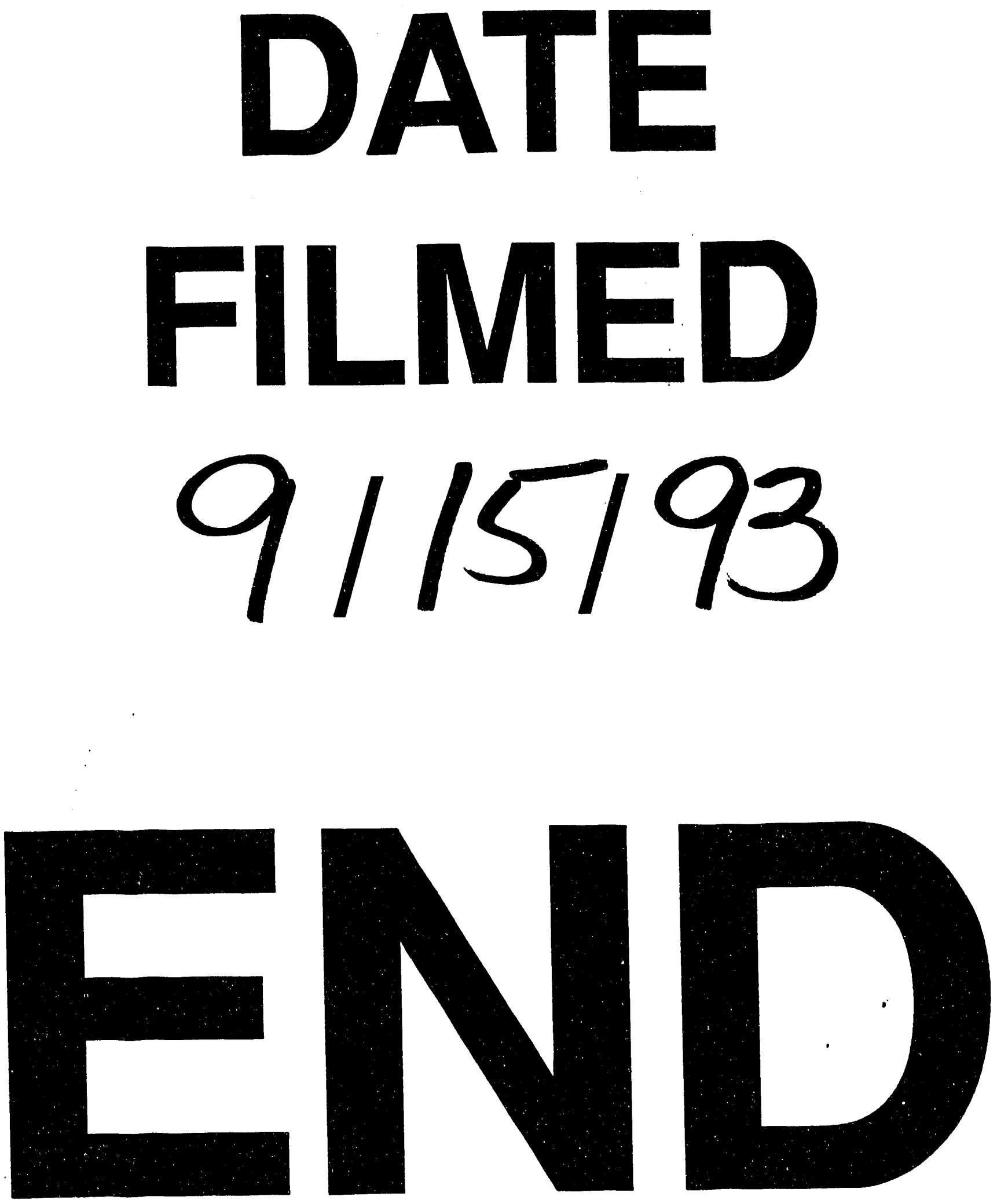
